\title{
globa:local architecture
}

\author{
by \\ Amir (Nima) Ahmadi \\ Bachelor of Architecture, Ryerson University, Toronto, 2007
}

\author{
A design thesis|project \\ presented to Ryerson University \\ in partial fulfillment of the \\ requirements for the degree of
}

Master of Architecture

Toronto, Ontario, Canada, 2012

(C) Amir (Nima) Ahmadi, 2012 



\section{Author's Declaration}

I hereby declare that I am the sole author of this thesis|project.

I authorize Ryerson University to lend this thesis|project to other institutions or individuals for the purpose of scholarly research.

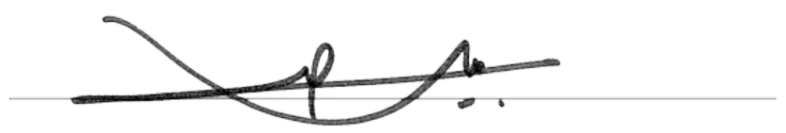

Amir (Nima) Ahmadi

I further authorize Ryerson University to reproduce this thesis|project by photocopying or by other means, in total or in part, at the request of other institutions or individuals for the purpose of scholarly research.

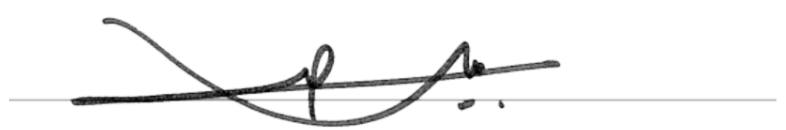

Amir (Nima) Ahmadi 



\begin{abstract}
How essential is it to understand the local context in a globalized world?

Globalization is a rapid traversing of ideas, attitudes and values across national borders that lead to an interconnectedness and interaction between peoples of diverse cultures and ways of life.

What if the local architectural mosaic depends on strengthening the capacity to invite people with different backgrounds and ideas to establish a connection to their heritage, whilst at the same time complying with globalized architecture? Is there a way to combine the freedom and flexibility of local cultures with the restrictive and regulatory influence of a globalized hierarchy?
\end{abstract}

This thesis explores the architecture that emerges out of the hybridization of multiple forces to be both locally unique and globally adaptable. 



\section{Acknowledgements}

I would like to express my heartfelt gratitude to my thesis supervisor Professor Arthur Wrigglesworth who offered vision, encouragement and support while I was pursuing this research and design.

I would also like to thank my advisor Professor Jurij Leshchyshyn for his much valued insight throughout the process.

I wish to extend my gratitude to my fellow colleagues at Ryerson University for their much appreciated feedback over the past two years.

I would not have contemplated this road if not for my parents, Rahim and Shokouh, who supported me by love at every stage of my education. To my parents, thank you.

And last, but not least, my lovely wife, Farnaz. This thesis would also not be possible without your love and support. Thank you for letting me be myself. 


\section{Table of Contents}

Page

Author's Declaration I

Abstract III

Acknowledgements $\quad \mathrm{V}$

Table of Contents VII

List of Figures $\quad X$

List of Appendices XII

1. Introduction 1

2. History of Globalization

2.1. Globalization Definition 4

2.2. Development of Globalization 4

3. Globalization \& Architecture

3.1. Effects of Globalization on Cities 8

3.2. Effects of the "McDonaldization" Phenomenon on Place 14

3.3. Globalized Architecture 18

3.4. Dilemma 1: How Can Architectural Style Characterize The 22

Value of a Multicultural Community?

3.5. Dilemma 2: With The Expansion of Global Construction 26

Knowledge and Power, How Will Architectural Praxis Evolve?

3.6. Conclusion 29 
4. Culture \& Architecture

4.1. The Implications of Cultural History in Architecture 32

4.2. Understanding Cultural Roots 40

4.3. Role of Architecture with Respect to Culture 44

4.4. Conclusion 45

5. Toronto \& Globa:local Architecture

5.1. Introduction 48

5.2. Why Globa:local Architecture Suits Toronto 49

5.3. Importance of Cultural Scenes 54

5.4. Importance of Local Nodes 55

5.5. Guiding Principles 56

5.5.1. Creating Quality Places 56

5.5.1.1.Creative Places $\quad 56$

5.5.2. Strengthening Social Cohesion 60

5.5.3. Economic Activity 61

5.5.4. Organizational Change 63

5.5.5. Fostering Creativity 63

$\begin{array}{lll}\text { 5.6. Conclusion } & 66\end{array}$

6. Design Proposal

6.1. Redistributing the Local 68

6.2. Design Methodology 69

6.3. The Vision 72 
Page

6.4. The Plan 74

6.5. Character of The Place 76

6.6. History of The Site 78

6.7. Location 80

6.8. Existing Public Transit 80

6.9. Project Components 82

6.9.1. Open Air Plaza 83

6.9.2. Event Plaza 83

6.9.3. Transit Hub 83

6.9.4. Retail Outlets 84

6.9.5. Bicycle Path 84

6.10. Project Drawings 85

7. Thesis Conclusion 99

$\begin{array}{lr}\text { Appendix } & 102\end{array}$

$\begin{array}{ll}\text { Reference List } & 154\end{array}$ 


\section{List of Figures}

Page

Figure $01 \quad$ Extent of the Silk Road and spice trade routes in $14^{\text {th }}$ century 3

Figure $02 \quad$ The global transportation network in $16^{\text {th }}$ century 3

Figure $03 \quad$ Colonization map $1800 \quad 3$

Figure $04 \quad$ Loading jute from wharf into export steamer, Calcutta, $1900 \quad 3$

Figure $05 \quad$ Oil refinery, California 3

Figure 06 Los Angeles cultural scene at the Grand Avenue Festival on Sunday, $\quad 7$

September 28, 2008

Figure 07

Dubai, $1990 \quad 10$

$\begin{array}{lll}\text { Figure } 08 & \text { Dubai, } 2003 & 10\end{array}$

$\begin{array}{lll}\text { Figure } 09 & 10\end{array}$

$\begin{array}{lll}\text { Figure } 10 & \text { Lujiazui skyline, Shanghai } & 13\end{array}$

$\begin{array}{lll}\text { Figure } 11 & \text { McDonald's restaurants by country, } 2003 & 13\end{array}$

$\begin{array}{lll}\text { Figure } 12 & \text { Starbucks store by country, } 2003 & 13\end{array}$

Figure $13 \quad$ View of the EMP Museum from the seattle Centre, Seattle 16

Figure $14 \quad$ Guggenheim Museum, Design by Frank Gehry, Bilbao 16

$\begin{array}{lll}\text { Figure } 15 & \text { EMP Museum, Design by Frank Gehry, Seattle }\end{array}$

$\begin{array}{lll}\text { Figure } 16 & \text { Cristo Redentor statue on top of Corcovado, Rio de Janeiro } & 17\end{array}$

$\begin{array}{lll}\text { Figure } 17 & \text { Eiffel Tower in foreground, Paris } & 17\end{array}$

$\begin{array}{lll}\text { Figure } 18 & \text { The exterior of the Colosseum, Rome } & 17\end{array}$

$\begin{array}{lll}\text { Figure } 19 & \text { St. Petersburg city, Russia } & 17\end{array}$

Figure 20 Tjibaou Cultural Centre in Noumea, New Caledonia, Design by Renzo 20

Piano

Figure $21 \quad$ The Battery project, Copenhagen, Designed by BIG architectural firm 21

Figure $22 \quad$ Shopping center, The Battery project, Copenhagen 21

Figure $23 \quad$ The first mosque built on Danish soil, The Battery project, Copenhagen 21

Figure $24 \quad$ Great Mosque of Djenne, the larget mud-brick structure in the world, 25 Djenne, Mali

Figure 25, 26, 27 Koudougou Central Market, Burkina Faso 27 
Figure 28 Spanish Pavilion, Designed by Foreign Office Architecture, Expo 2005, Nagoya, Japan

Figure 29, 30, 31 National Assembly Building of Bangladesh, Design by Louis Kahn 34

Figure 32, 33, 34 The village of New Gourna, Opposite Luxor, Upper Egypt, 1945-1948 36

Figure 35 India Tourism campaign based on the cultural roots experiences. 2009 Toronto International Film Festival.

Figure 39

Figure 40

Figure 41

Figure 42

Figure 43

Figure 44

Figure 45

Figure 46
Kensington Market on a Sunday morning.

Chinese Lantern Festival Pavilions with Cinesphere at Ontario Place on Toronto's waterfront

During Luminato festival, Toronto's public spaces become open canvas for street artists. In the above image Yonge-Dundas square is used for Luminato Festival Light on Your Feet Dance Project.

During Luminato's Great Canadian Tune last summer 1,623 gathered to play Neil Young's Helpless in Yonge-Dundas Square. Photo courtesy of Luminato Festival

The vision of the Artscape's Wychood Barns is to make a year-round hub of activity that engages the many communities

Wish Come True Festival 2010, Photo courtesy of Luminato Festival Bandshell Park at Exhibition Place, Toronto

Philip Beesley responsive art installation 2010, Sargasso, transformed Brookfield Place, Toronto

Federation Square, Home to major cultural attractions, and world-class events that has become the Melbourne's meeting place. Melbourne, Australia 
Figure 47

Figure 48

Figure 49

Figure 50

Figure 51

Figure 52

Figure 53

Figure 54

Figure 55

Figure 56

Figure 57

Figure 58

Figure 59

Figure 60

Figure 61

Figure 62

Figure 63

Figure 64

Figure 65

Figure 66
View toward southeast and Queen Street West and Dufferin Avenue Intersection.

Use the lands around CN Rail corridor to develop a globa:local place 70 View toward Northwest from CN Rail corridor 71

Vertical circulation diagram with the proposed site amenities

Looking west on Queen Street West towards underpass tunnel 75 Looking at the intersection of Queen Street west and Gladstone Avenue.

Looking at the Gladstone Hotel that acts as a cultural node in this neighborhood

Looking on Dufferin Avenue toward south and seeing the new underpass tunnel

The new outdoor amphitheater right and the intersection of Dufferin Avenue and Queen Street West

View looking north at the CN Rail tracks and the small parking area next to that

Gladstone Hotel designed by George Miller, 1889. The Hotel was designed in the Richardsonian Romanesque style a popular Victorian style for public buildings such as train depots, churches, and libraries. South Parkdale Station at queen street west and Dufferin Street, 1910 Aerial view of Queen Street subway at Dufferin Street looking west, 1898

Neighborhood Landmarks

View of train station platform towards Queen Street West.

View from market hall towards retail, station, and the parking.

View from parking level toward the market hall.

View from transit level and its connection to outdoor plaza. 


\section{List of Appendixes}




\section{Introduction}

This globa:local architecture thesis investigates the fundamental link between culture, economy and place in the age of globalization.

An exciting local cultural life does many things for a global city. It provides opportunities for critical reflection and collective experience. It creates mutual understanding for spontaneity, surprise, and celebration. It understands and carries forward traditions. It experiments with new forms of expression, communication, and feeling. It forges a shared identity. Local cultures make the city a more livable and enjoyable place for all.

So the question is what does the place do for local cultures? A short answer to this question would be that the place allows local cultures to gather and create moments. Usually artists use these places to create "scenes" that become destinations for city inhabitants and eventually become starting points for globa:local endeavors.

Globa:local is about relating to the whole world but with an impact or significance to a particular area or neighborhood; it is thinking on a global scale and acting at a local level.

As stated in the body of this thesis, culture is an essential part of any local 
community's existence in today's competitive global economy. Local cultures play a key role in the quality of life of all those who live in the city by enhancing them through ideas, innovations and amenities that flow from a vibrant local cultural life. This thesis offers insight into contemporary thinking on a global scale and maintaining strong involvement with local cultures, in order to act at a local level.

It provides tools for leveraging the phenomenon of globa:local architecture to support other industries and enhance the competiveness of local cultures on the world stage. It offers architects a deeper understanding of how to acknowledge where cultural nodes occur and how they can be further cultivated.

Globa:local architecture presents a new model for understanding local cultures. This model can be used to develop new plans, and to work more closely with other active participants of communities in order to build a strong and vibrant cultural life for everyone by increasing Toronto's global competitiveness. However, it needs to be emphasized that there is no simple answer. In some towns and cities people may relate to this idea quite naturally, while in other places it might be received as a series of policies that are not clear or aligned.

Therefore, given the size, scale, and growth of local cultures, as well as their importance to competitiveness and prosperity, Toronto should nurture and invest in its cultural sector.

It is hoped that this research creates a focus on the value of globa:local architecture in contributing to the sustainability of local cultures. 

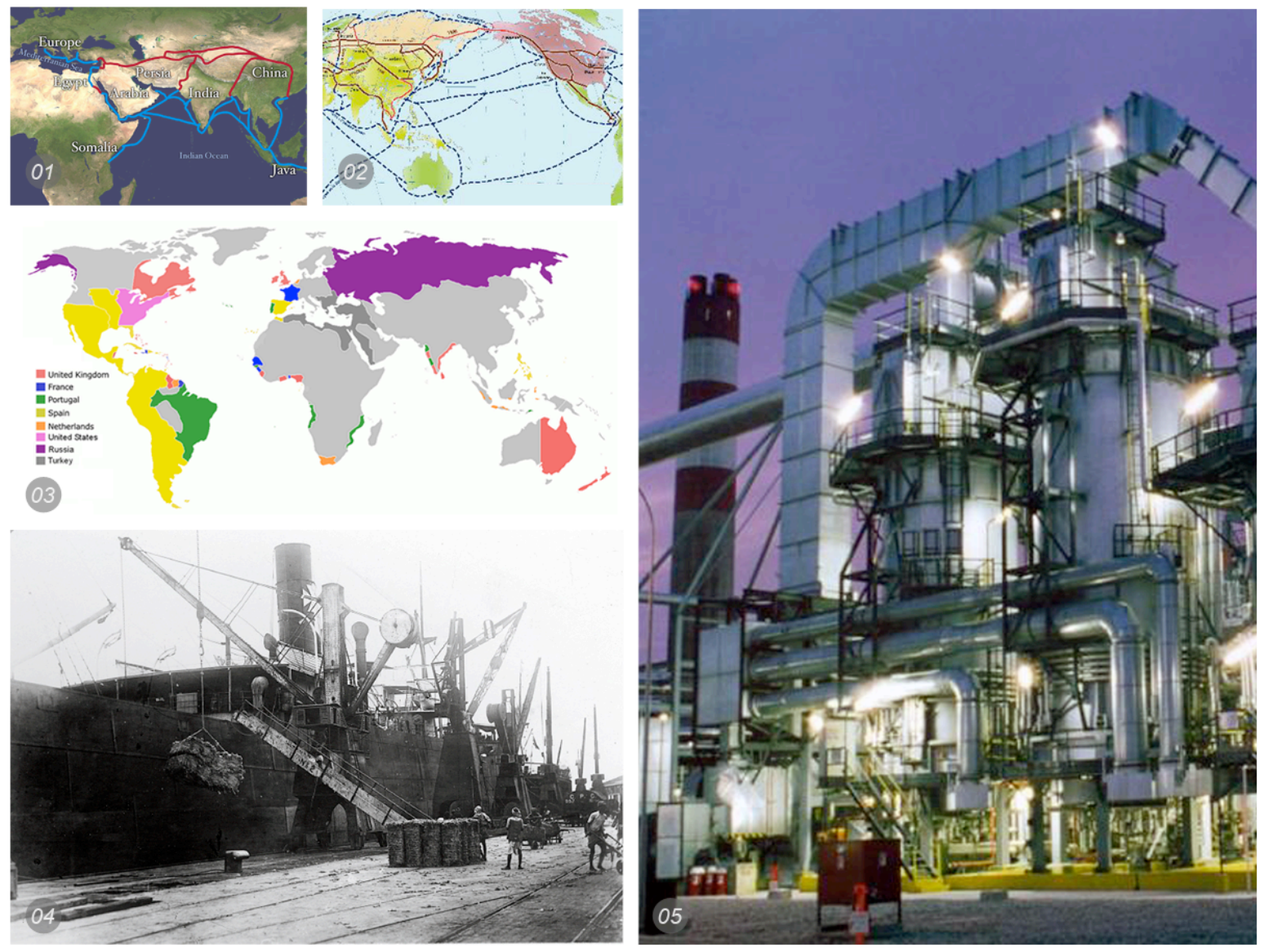

Figure 01

Extent of the Silk Road and spice trade routes in $14^{\text {th }}$ century

Figure 02 The global transportation network in $16^{\text {th }}$ century

Figure 03 Colonization map 1800

Figure 04

Figure 05

Loading jute from wharf into export steamer, Calcutta, 1900

Oil refinery, California 


\section{History of Globalization}

\subsection{Globalization Definition}

"Global" is the phenomena of interconnectivity of localities and spatial attributes through social, economic, cultural, and political life. So a global space or geography is a domain of connectivity spanning distances and linking localities to one another, which can be portrayed on maps by lines indicating routes of movement, migration, translation, communication, exchange, etc. "Globalization" is the physical expansion of the geographical domain through an increase in the scale and volume of global flows and the increasing impact of global forces on local life. Moments and forces of expansion mark the major turning points and landmarks in the history of globalization.

\subsection{Development of Globalization}

Throughout recorded history people have linked together disparate locations on the globe into extensive systems of communication, migration, and interconnections. This interaction between global and local has been a central driving force in world history. 
In 1350, networks of trade, which involved frequent movements of people, animals, goods, money, ran from England to China. They ran through France and Italy across the Mediterranean to the Levant and Egypt, and then over land to Central Asia (the Silk Road) and along sea lanes down to the Red Sea, across the Indian Ocean, and through the Straits of Malacca to the China coast. The result was the Segmented Trading World of Eurasia (Figure 1).

During the sixteenth century, the sea-lanes produced competition for access to ports and for routes of safe transit that did not reduce the overall volume of trade or the diversity of trading communities but did channel more wealth into the hands of armed European countries for control of the sea. The Indian Ocean became more like Central Asia in that all routes and sites became militarized as competition between European countries accelerated over the sixteenth and seventeenth centuries. The objective was to control access to the sea-lanes by military means (Figure 2).

Through the seventeenth century, commodities trading concentrated on local products from each region of the Eurasian system, such as Chinese silk and porcelain, Sumatra spices, and Malabar cinnamon and pepper. Eventually long distance trade became a deeply entrenched part of the production and distribution process.

The eighteenth century was the age of mercantilism, during which state power depended directly on the sponsoring and control of merchant capital, and merchant capital expanded under the direct protection and subsidy of the state treasury. By end of 1700 s competing European powers controlled the Atlantic economy (Figure 3).

Basic eighteenth century economic conditions continued well into the nineteenth century, until the railway and steam ship began to lower transportation costs significantly, and to create new circuits of capital accumulation that focused on sites of industrial production in Europe and the USA (Figure 4). 
The integration of separate specialized world regions of agricultural and industrial production within a world economy of capital accumulation occurred during the nineteenth century. The industrial technologies of the factory, railway, telegraph, gun, and steam ship facilitated this development; but as important were the organizational technologies of modernity, which included state bureaucracy, land surveys, census operations, government statistics, and national legal systems (Figure 5).

The result was not only integration of regions into one world system of production, but also the construction of a single world of rules and regulations for the operation of the system. The "globalization" phenomena did not happen overnight; it has been a dominant economic, political, and cultural driver since the start of the twenty-first century. 


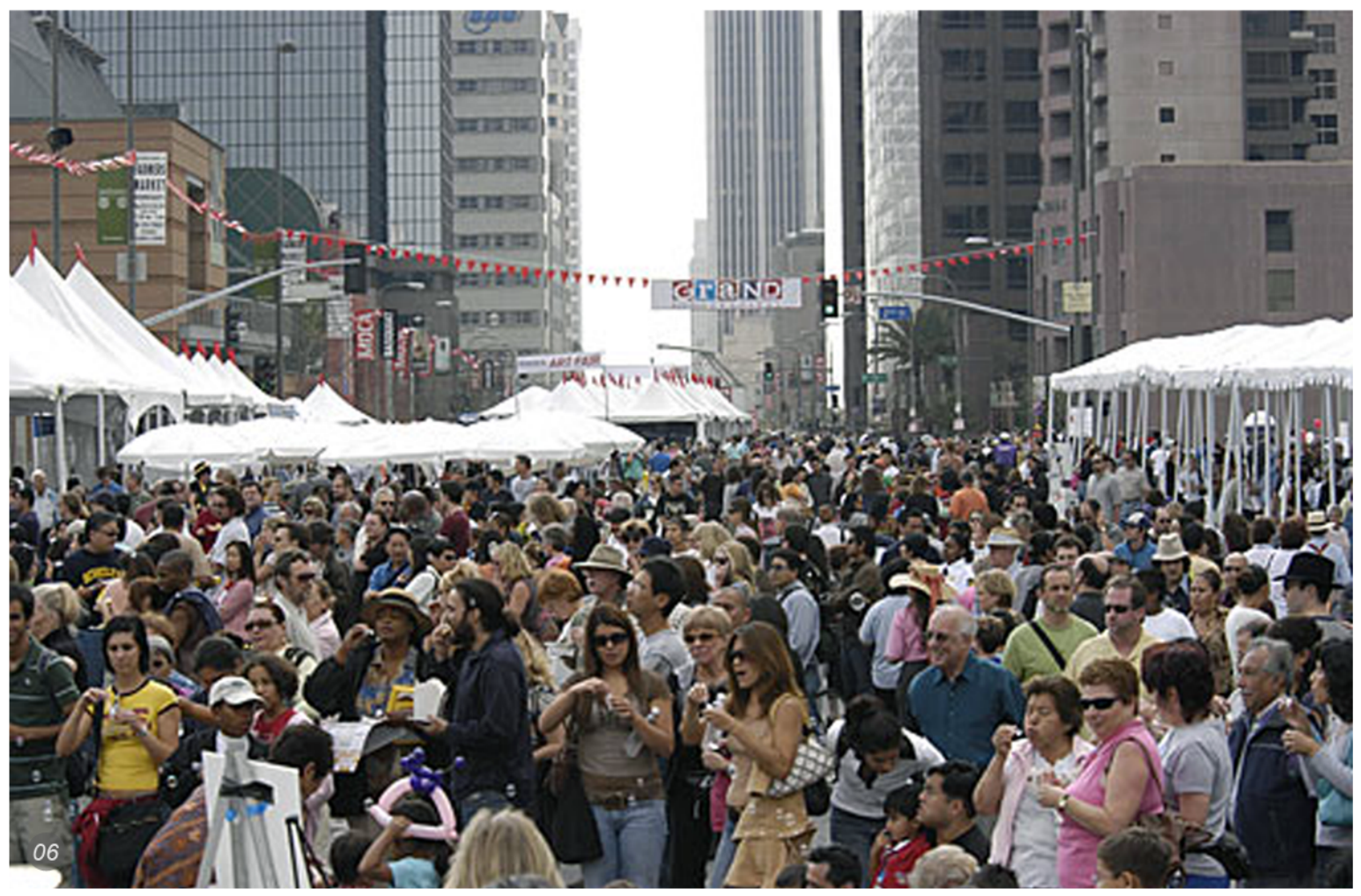

Figure 06 Los Angeles cultural scene at the Grand Avenue Festival on Sunday, September 28, 2008 


\section{Globalization \& Architecture}

\subsection{Effects of Globalization on Cities}

Globalization is a term packed with a rich and complicated range of possibilities that raises important questions about architecture and its outcomes. Usually, the word "globalization" is associated with flows of capital, products, labor and ideas that have blurred national boundaries. Globalization often suggests images of a shrinking world, in which accelerating flows of information and travel technology compress time and space in the relationships between world cultures, political economies and the built environment.

Cities that once hosted people of one nation now host a rich range of worldwide citizens through processes of globalization. Continually redefined by the people who occupy them and their requirements, cities are no longer singular 'wholes' but molecular compositions that are differentiated. Whereas a nation formerly provided cities with a singular ideal identity, cosmopolitan societies that inhabit contemporary cities are made up of diverse and active groups that co-habit the city internally and are unite by "connected isolations" 
${ }^{1}$ (Figure 6). Philosopher Kwame Anthony Appiah argues that even in our world of opposing ideas, there are many similarities and shared values amongst individuals that transcend boundaries.

Through their wide distribution of travelers, Toronto, Cairo, and Kuala Lumpur are being

drawn ever closer together. Hybrid identities and cultures are emerging through the Intersection and combination of identities with other identities, which then creates social integration. So the local citizen of the twenty first century is generated through hybridity and the transformation that arises from new and unexpected combinations of cultures and ideas.

As an example we can look at Dubai urban planning strategies. With ambitions to become a hub of global commerce, a top tourist and shopping destination, Dubai has been spending billions of dollars to build an astonishing modern city nearly from scratch in a mere 15 years. Dubai is not like London, Paris or New Delhi, which have been shaped through a long process of evolution; it is 'instant' in that it is the product of a super-fast urbanism. But the question is why the city grew from a rural fishing and trading center to a modern city competing for a place in the global economy?

After the discovery of oil in 1967, Dubai embarked on major planning efforts to modernize its built environment: freeways, transport infrastructure and green spaces. At that time the old and historical rural form was destroyed both by government and property owners.

Today Dubai is a globalized city where different ethnic groups are represented: locals, Arabs, Indians, Iranians, Asians, and Westerners. In fact the local population in the city is a minority; they account for only $20 \%$ of the estimated 2.2 million city inhabitants. Dubai has become an attractive

\footnotetext{
${ }^{1}$ K. Anthony Appiah, Cosmopolitanism, Ethics in a World of Strangers, Princeton University Press
} 2004. 

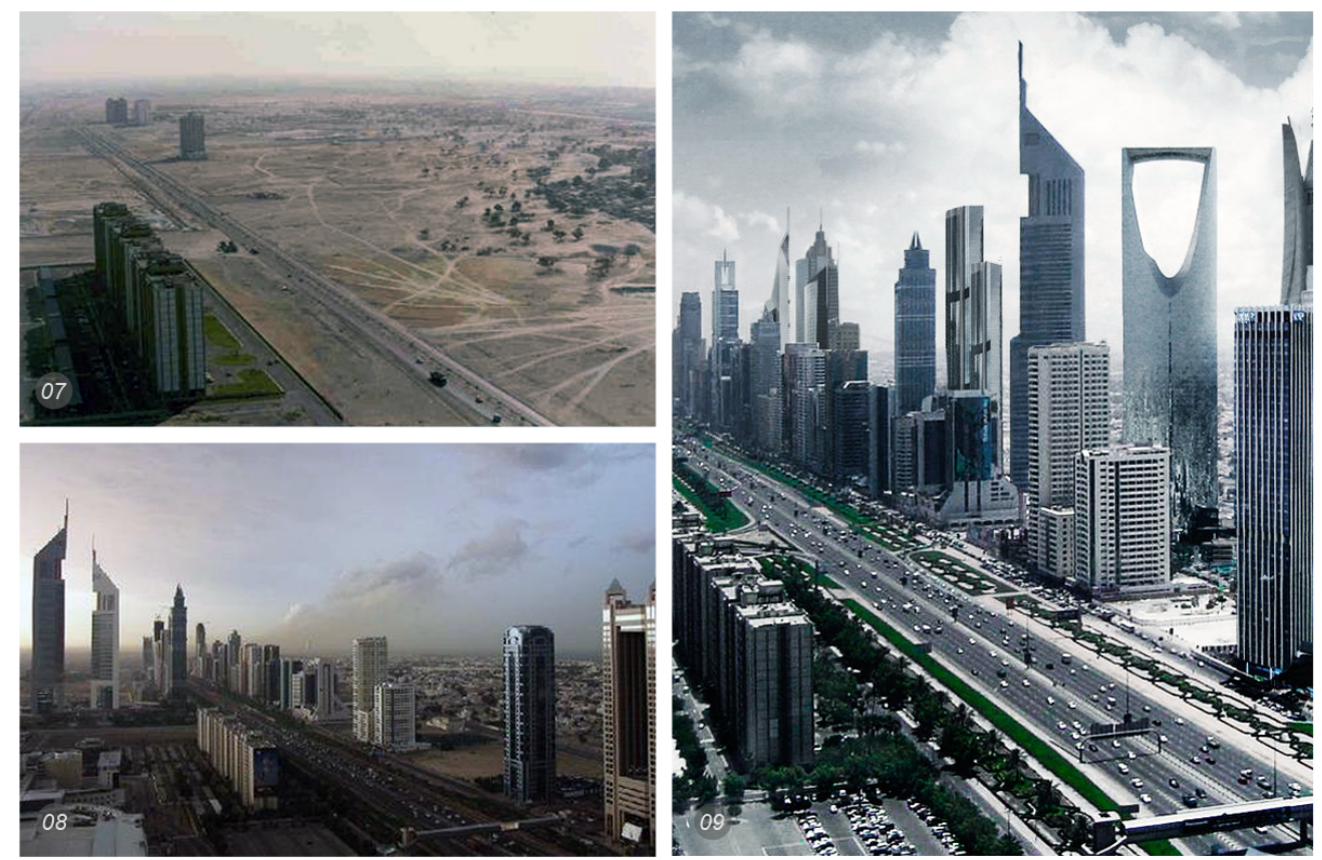

Figure 07 Dubai, 1990

Figure 08 Dubai, 2003

Figure 09 Dubai, 2030

destination for artists, athletes, and businessmen either to visit or live. And, as a result of globalization, Dubai has been described as one of the fastest growing cities in the world today. The debate over citizens of twenty-first century cities is a topic that has resulted from such new urban planning strategies (Figure 7-9), where many ethnic groups are presented. But the question is: are these people living in twenty-first century cities active participants in the 'same' society? It should also be acknowledged that the effects of globalization on cities are far deeper than beautiful architecture or sustainable economies. Issues such as segregation are a major subject in today's globalized cities.

Whereas the architecture of a city once represented a single nation and culture, today it symbolizes multiplicity. Architects produce options in the form of buildings and, in doing so, make decisions on behalf of future inhabitants. But there is a limit to how many options an architect can incorporate in a building. For instance, to the casual observer, Peter Eisenman's buildings 
seem to challenge the conventional logic of architecture. Eisenman has said that architecture's most fundamental properties are not shelter and enclosure, and that his buildings are not about aesthetics. Rather, their skewed axes and geometry, grids layered horizontally and vertically, and compositions that are illegible, often times a seeming chaos of fractured and fragmented elements, substantiate his declaration for a singular role and expression of architecture as analogous to the multiplicity of a city's culture and society.

So I think buildings are required to fit within a certain set of fixed requirements and always seek equilibrium. 

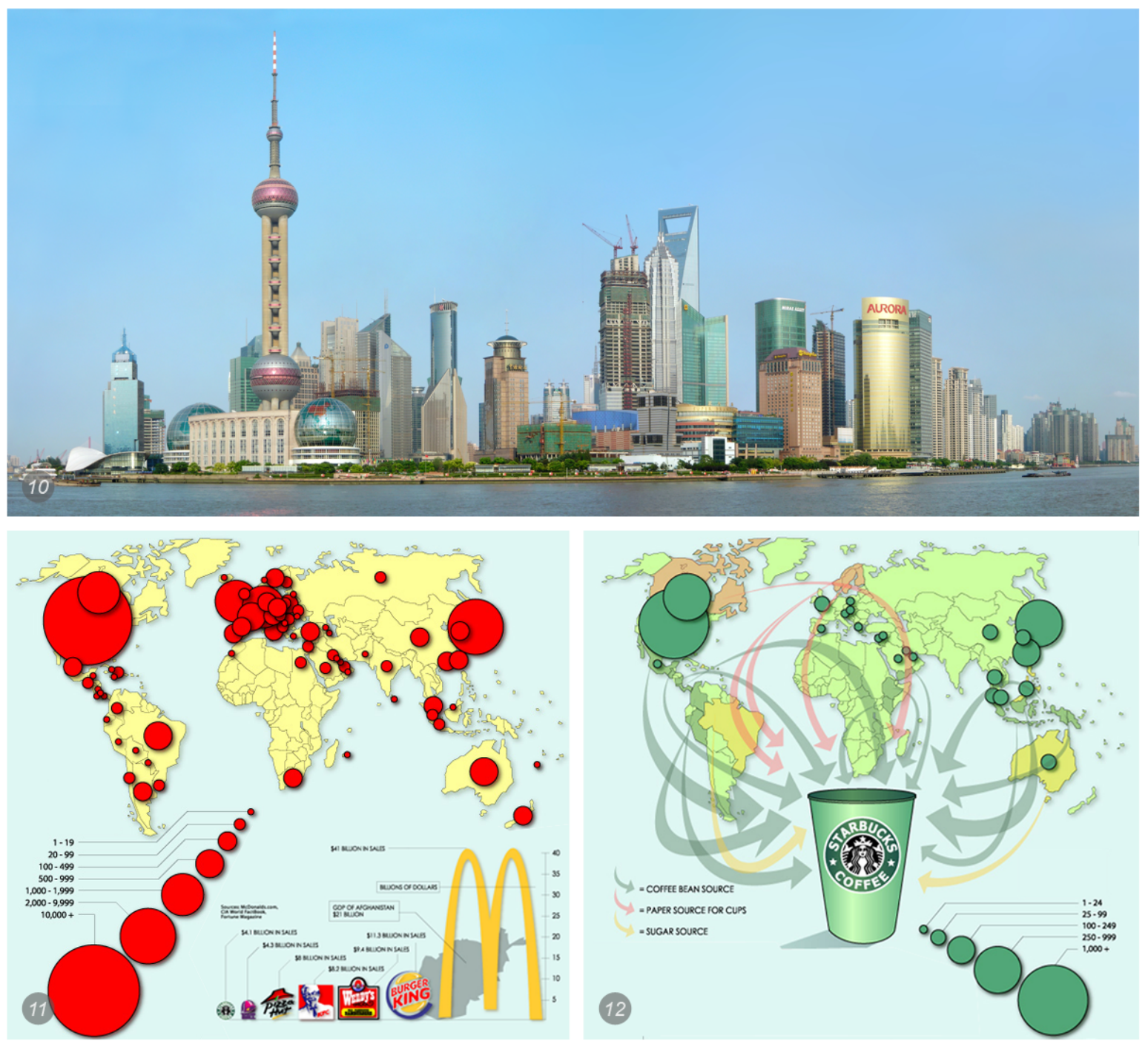

Figure 10 Lujiazui skyline, Shanghai

Figure 11 McDonald's restaurants by country, 2003

Figure 12 Starbucks store by country, 2003 


\subsection{Effects of "McDonaldization" Phenomenon on Place}

The term McDonaldization is attributed to Dr. George Ritzer who, in 1993, used it to refer to the trend of applying the characteristics of the fast food industry to more areas of modern life. McDonaldization is a reconceptualization of rationalization, or moving from traditional to rational modes of thought, and scientific management (Figure 11-12).

Place is one of the important issues within the debate on globalization. A lot of arguments about this subject have involved the architecture as an agent of the "McDonaldization" phenomenon, in which global trade, capital and ideas are construed as forces that threaten local culture. A place is a social space that is open and accessible and where people are able to congregate, but within this context, place becomes something that is on the edge of being lost to an outside force beyond the control of people within particular locations.

The cultural transformations of globalization in reference to McDonaldization are disputed because it suggests a one-dimensional process. Some critics say globalization actually gives new meaning to local as a narrowly geographic place and some argue that globalization replaces exclusive distinction with conformity to a single cultural model. However, I think globalization and localization are two sides of the same coin because together they create trans-local places at one time. Within the trans-local view, you can find different types of distinctions as exclusive or inclusive.

Greig Crylser, as one of the authors of The SAGE Handbook of Architectural Theory (2011) suggested that by moving the debate beyond the simple binaries that oppose the local to the global, and the fixed to the fluid, the idea of place can be changed, becoming not so much a static source of authentic and rooted culture as a site of contest and contradiction (Figure 10). On the other hand, we have seen many architects of deconstruction, who used collage to express variety but failed to make new combinations. Since buildings in their completed state are not conducive to Appiah's 'endless process of imitation and revision', the pursuit of cosmopolitanism should be 
diverted to the architectural process, to see if architecture can emerge out of the hybridization of multiple forces and materials and, like people, be both unique (local) and plural (global).

There are many examples of McDonaldization but the one I chose to look at is the Experience Music Project and Science Fiction Museum and Hall of Fame (EMP) Museum in Seattle, Washington, USA.

After seeing the Guggenheim Museum in Bilbao (Figure 14), Spain, the developers of the EMP Museum hired its architect, Frank Gehry, to design a museum dedicated to the history and exploration of both popular music and science fiction. The museum building is located on the campus of the Seattle Center and comprises 140,000 square feet $\left(13,000 \mathrm{~m}^{2}\right)$, with a 35,000 square-foot $\left(3,300 \mathrm{~m}^{2}\right)$ footprint. Much of the building material is exposed in the building's interior. The outside of the building features a fusion of textures and colors, including gold, silver, deep red, blue and purple (Figure 13).

Nearly ten years after the EMP museum opened its doors to the public amid much pomp and ceremony, promising 21st century access to a treasure of memorabilia from the history of popular music, it has seen suffered from a series of austerity measures.

Expectations for the US\$100 million, 140,000-square-foot extravaganza were high, with visions of rotating, interactive exhibits that would not require financial support from billionaire co-founder Paul Allen and his sister, Jo Allen Patton. However, staffers are now nervous about job security after three rounds of cuts that reduced the original workforce of 515 workers to the current 250. And, although attendance in the museum's first year was 800,000 , the annual attendance has settled at around 400,000 , which is $60 \%$ less that the expected number of attendees.

As a result, the architecture itself has received mixed reviews. Seattle Times Writer Jonathan Raban wrote that Frank Gehry "has created some wonderful buildings, like the Guggenheim Museum in Bilbao, but his Seattle effort, the 
Experience Music Project, is not one of them."

The EMP museum is unquestionably a victim and a by-product of the McDonaldization effect and, in my opinion, there is no harmony between the building and the land, or between the building and any of the buildings in the vicinity (Figure 15).
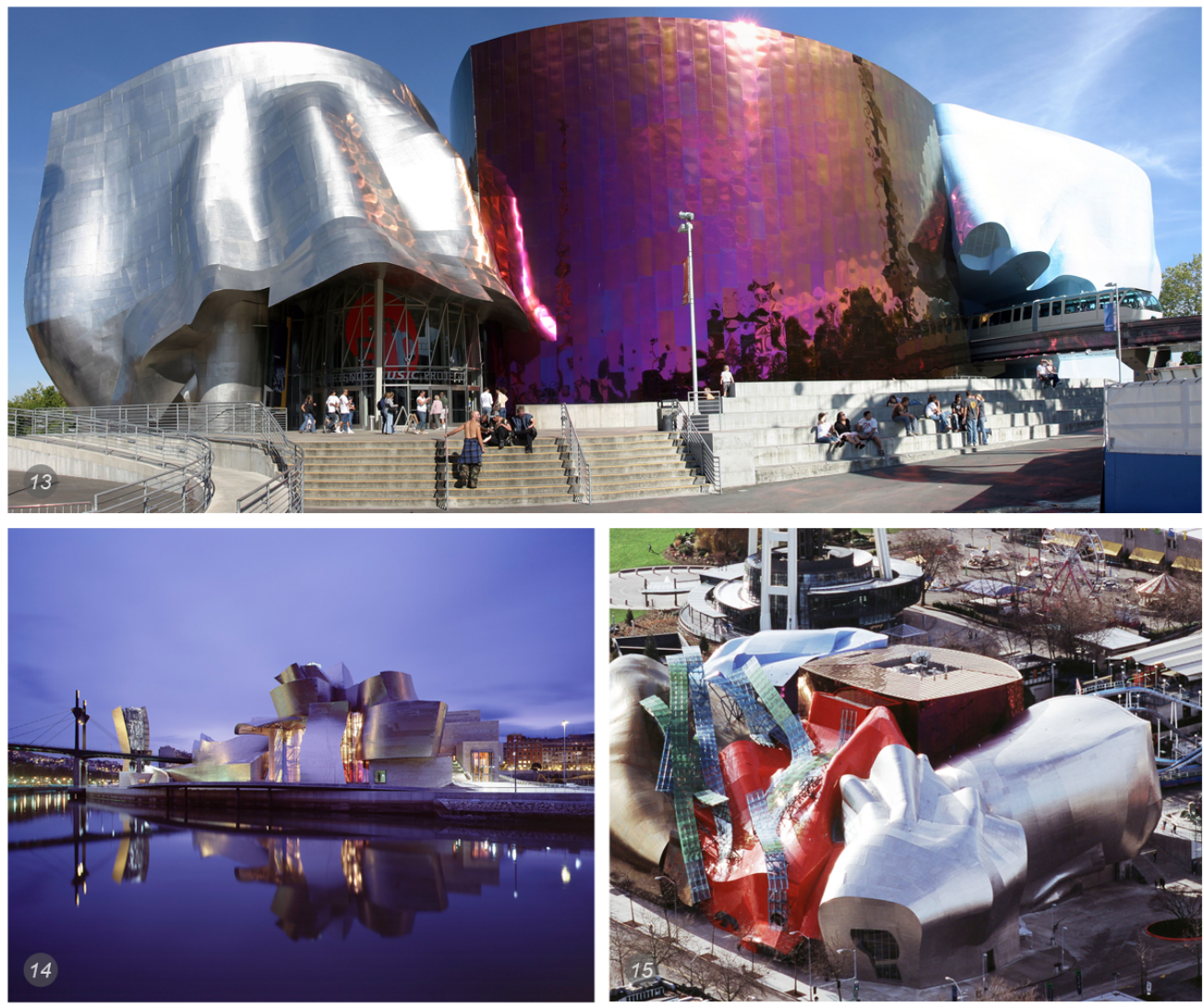

Figure 13 View of the EMP Museum from the seattle Centre, Seattle

Figure 14 Guggenheim Museum, Design by Frank Gehry, Bilbao

Figure 15 EMP Museum, Design by Frank Gehry, Seattle

Now that differences are found everywhere, it seems that the critical question for architecture has changed. Instead of declaring that differences are uncombinable, the point is to recognize differences that are remarkable, look for connections, describe systems of intervention, and find larger areas of consistency among these differentiated entities that can produce new hybrid architecture. 

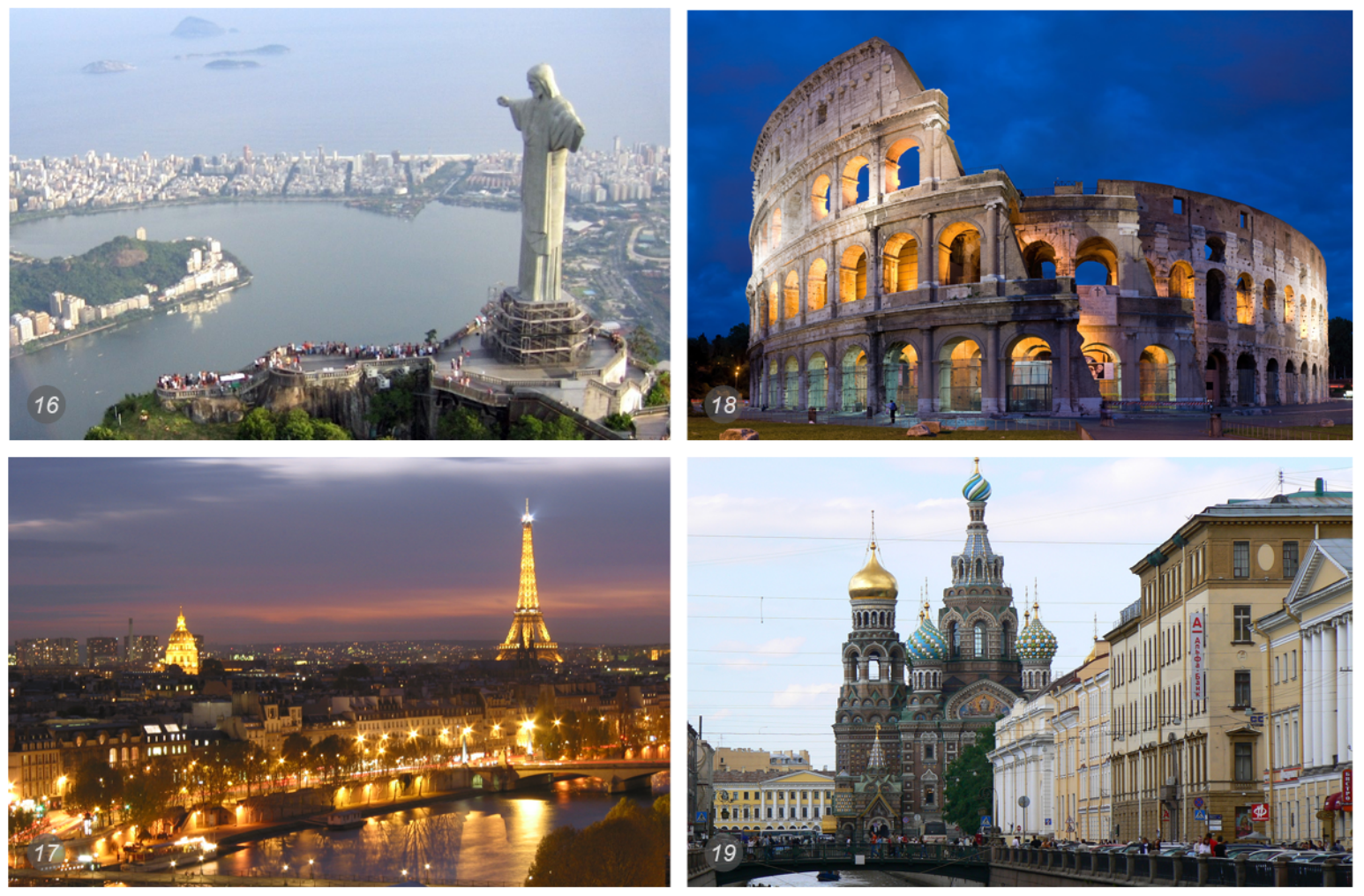

Figure 16 Cristo Redentor statue on top of Corcovado, Rio de Janeiro

Figure 17 Eiffel Tower in foreground, Paris

Figure 18 The exterior of the Colosseum, Rome

Figure 19 St. Petersburg city, Russia 


\subsection{Globalized Architecture}

What should new architecture look like in Rio, Rome, St. Petersburg, or Paris (Figure 16-19)? Should it literally replicate historic architecture? Among the architectural fraternity, some welcome the architecture of modernity and globalism and others deplore it, seeing it as a threat to authentic, indigenous culture in general and to the character of regional architecture in particular.

People love to visit iconic cities such as St. Petersburg, Paris, Rome, Venice, Agra and Bangkok, or wander through picturesque towns and villages in Tunisia, Greece, Spain, Mexico, Japan, and the United States. Part of what appeals to us about all these places is their architecture: unique and locally distinct, venerable, recognizable, generated by particularities of site, climate, culture, and locally available materials and construction technology. Most inhabitants of these places, as well as those who love visiting them, strive to safeguard the established forms and decorative motifs associated with traditional architecture. They value historical continuity, cultural diversity and preservation of geographic identity, all symbolized by a particular architectural language and vocabulary, just as a spoken language and local dialect impart identity.

I think the challenge of globalization is to find the right balance, the artful compromise between preservation of the old and introduction of the new.

For instance in his essay "Architecture and the Global City" Lewis (2002) explains that in St. Petersburg challenges arise whenever someone proposes to construct something new or modify an existing historic structure; there is always much heated debate. The architect usually has to face a multitude of questions in relation to how the proposed project will change or adversely affect the look of the city. Will the project fit in aesthetically? Why compromise or spoil forever the original architecture of even a single 18th or 19th century palace?

Such challenges may not be felt in new global cities whose architecture was 
created during the 20th century, cities such as Miami, Houston, Los Angeles or Sydney. But cities such as Beijing, Shanghai, Tokyo, Singapore, Mexico City or Montreal all encompass architecture and embody historic architectural traditions that could easily be eclipsed, if not destroyed, by architectural globalization.

The Chinese have been especially ruthless in engaging in the wholesale demolition of historic urban infrastructure, residential neighbourhoods, and traditional structures, to make way for new and aesthetically uninspiring modern buildings. In spite of China's culture, which is mythical and is based on discourses of timelessness, whose effects remain significant in China's contemporary political life, China's modern architecture is littered with artificial poorly crafted architectural compositions exhibiting the worst stylistic characteristics of postmodernist design, often been described as a materialized utopia excelling in simulations like Disneyland and Las Vegas. These buildings could be situated just as easily in New Jersey.

Often, the traditional architecture of a region, suggests how modern architecture can be made more sustainable, since builders in previous centuries had to rely entirely on natural means to make habitable environments. Indeed, the more a contemporary building responds to local climatic conditions and energy conservation opportunities, the more likely it is to feel regional as well as modern. But this is difficult to accomplish, and even more difficult to accomplish well. It requires great sensitivity and substantial talent to successfully weave together appropriately chosen, traditional characteristics and elements with technologically modern characteristics and elements. It requires a regionally derived, form-making language, with its own compositional grammar and vocabulary of materials and details to design an office building in Moscow different from one in Mexico City, even though both may be functionally identical. 


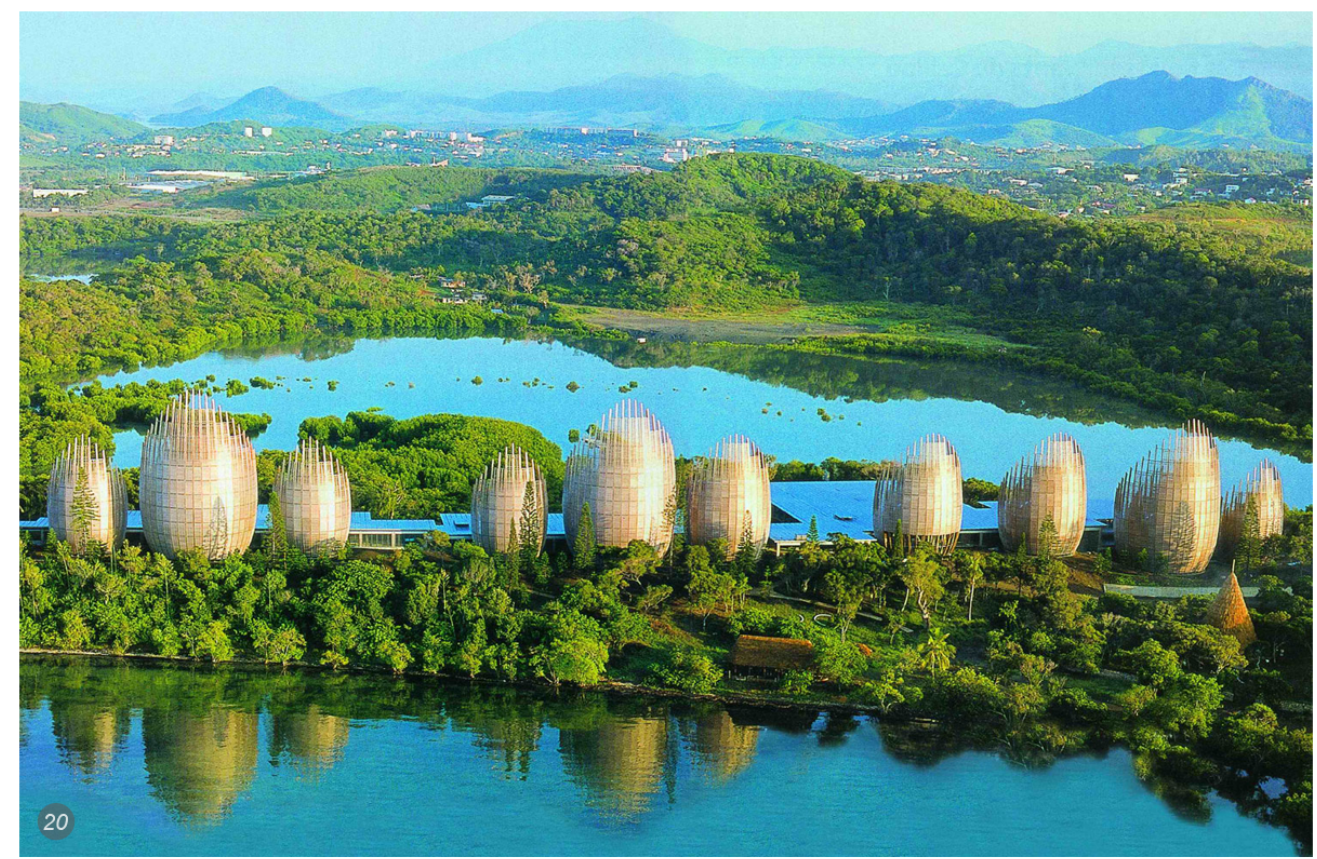

Figure 20 Tjibaou Cultural Centre in Noumea, New Caledonia, Design by Renzo Piano

Renzo Piano, among today's most creative and respected modern architects practicing internationally, explained clearly what architects must do in this era of new global history.

"I believe that the architect must lead a double life. On the one hand is a taste for exploration, for being on the edge, an unwillingness to accept things for what they appear to be: a disobedient, transgressive, even rather insolent approach. On the other hand is a genuine, and not merely formal, gratitude to history and nature: the two contexts in which architecture has its roots. Perhaps this double life is the essence of the only humanistic approach possible today." 

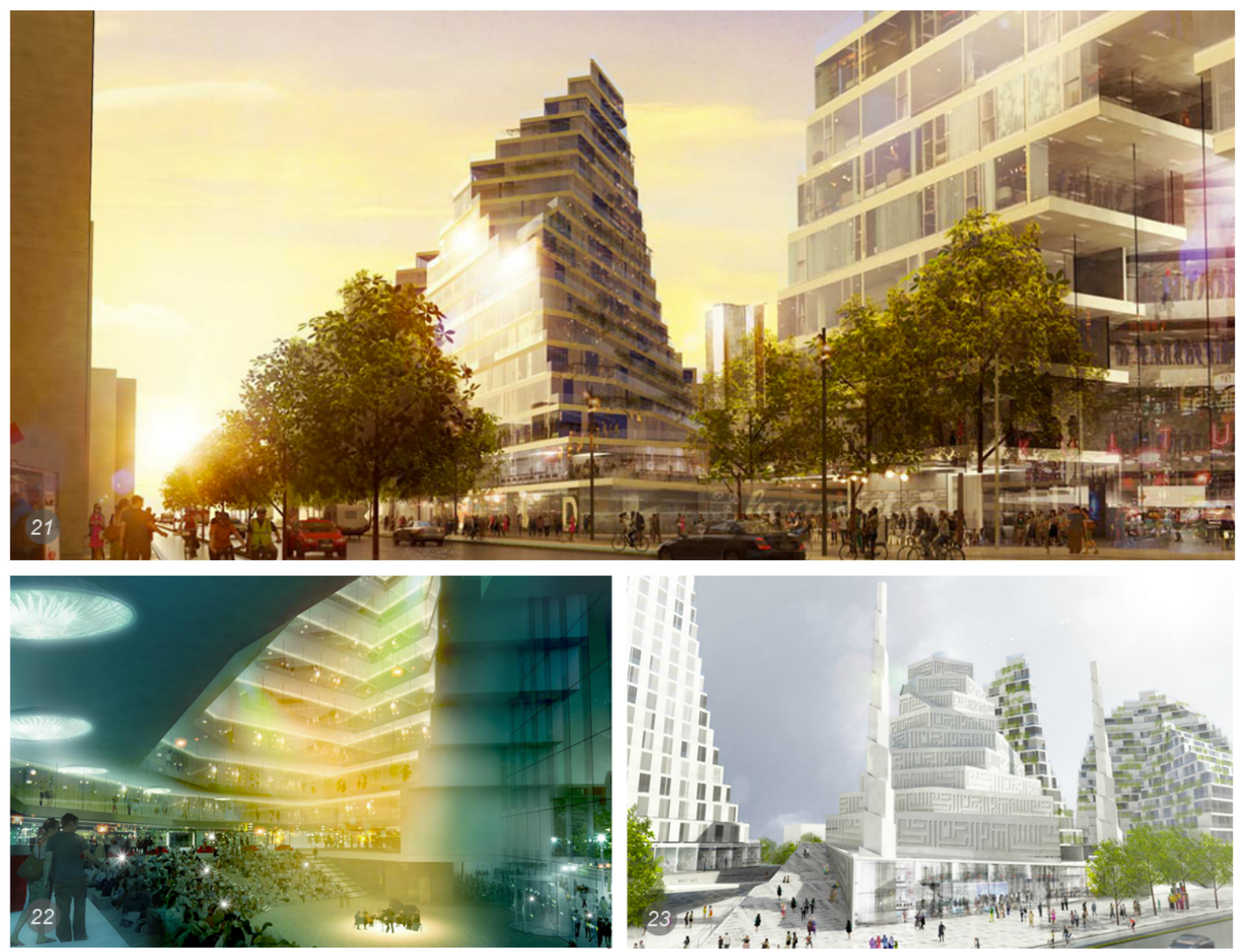

Figure 21 The Battery project, Copenhagen, Designed by BIG architectural firm

Figure 22 Shopping center, The Battery project, Copenhagen

Figure 23 The first mosque built on Danish soil, The Battery project, Copenhagen 


\subsection{Dilemma 1: How Can Architectural Style Characterize The Value of a Multicultural Community?}

One of the dilemmas architects face today is how to characterize the values of a multicultural community within a global city.

The language and form of a building can hold significant meaning and symbolism. Contemporary Buildings often attempt to incorporate ornaments and symbols in their form or facade; however, many of these attempts are simply applied styles, which play off of nostalgia. Rather than seeing culture as static and a thing of the past, culturally appropriate designs acknowledge that the built form shapes as well as reflects culture (Eggener, 2007). The Egyptian architect Hassan Fathy sought to strengthen communities through the use of local materials and vernacular building techniques and strategies. He felt that through this strategy he could help re-teach cultural heritage and techniques to the residents. Fathy studied pre-industrial building systems of Egypt in order to understand their aesthetic qualities, learn climate control techniques, and implement economical construction techniques in a contemporary way. In his book, Natural Energy and Vernacular Architecture, Fathy (1986) criticizes how architects have substituted vernacular strategies for modern materials or forms and explains how both the material and its usage are vital to maintaining a appropriate design. He explains why this is often feels "physically and psychologically uncomfortable" in these modern buildings and that particular groups of people may feel that their entire culture is being disregarded and replaced by a foreign architectural language. Moreover, the performance of the building and response to climate may be significantly sacrificed simply for what the architect feels is a more fashionable or interesting design.

A contemporary project that deals with the issue of architecture for multiculturalism is the "BAT Faste Batteri", also referred to as the Battery, in Copenhagen, Demark, designed by the Bjarke Ingels Group (Figure 21). This project is about integration. It seeks to integrate all aspects of city life into a unified environment of apartments, offices, shopping, child care 
provisions, sports facilities, cultural institutions, hotels (Figure 22). It also seeks to facilitate the cultural integration of Islamic and Danish culture, by incorporating the first mosque ever built in Denmark (Figure 23). The design brings together the three disparate urban quarters of Brygge, Amagerbro, and $\varnothing$ restaden into one overlapping urban activity centre and fuses landscape and architecture (the natural and built environments) into a unified urban topography of peaks, valleys, cliffs and caves. This architecture is free from the stylistic straitjacket to generate new associations from the architectonic spectrum.

The urban fabric of the area represents a cross section of the multicultural society in Copenhagen. The project will serve one of the most socially diverse communities in Denmark. Through art and cultural activities, the project hopes to bring together residents from the apartments, and the general public.

The architectural design of the project is derived from the study of Copenhagen's Coat of Arms, which opens up an interesting insight into the city's heraldic self-perception. Three towers stand side by side with their feet in water, with the spire of the highest tower crowned by a half moon. The image is one of a modern harbor-front multicultural metropolis populated with life and towers.

The design of the complex as a whole is contemporary while users experiencing any particular part of it are able to sense and appreciate a traditional local atmosphere. The beautiful and functional design provides educational and cultural activities and the possibility of expansion into the landscape of the surrounding public park.

The design concept reflects BIG's love of contemporary art and culture. The design of the buildings captures the dynamism of the urban spirit and landscape through use of peaks, valleys, cliffs and caves. From the terraced slopes the residents will be able to admire the Copenhagen skyline with its plethora of historic towers and spires. People will pass through the terraced 
landscape, which is designed in such a way as to provide a network of routes between the three different urban quarters. The valley provides a sheltered oasis for the children of the integrated playschool. The caves constitute a large unified public space, ranging in scale from the human to the monumental. They contain a bazaar, shops, sports facilities, a spa, a playschool and lots of other publicly accessible facilities. A dome in the heart of the development will become the first mosque built on Danish soil; a promise of a fertile future for the coexistence of Islamic and Danish society. The proposed design stands as a statement of how space can be a medium that seamlessly connects movement, nature, light and activities from outside to inside and vice versa.

So the question is whether, in a country such as Denmark that is wary of foreigners living in their midst, is it possible to have a multicultural neighborhood of such extreme urban density? The architect's response to this question is that "The Tower of Babel collapsed because of confusion between the different languages. The new peaks of the Battery will stand precisely because of the multicultural diversity of religion, activity, and architecture." 


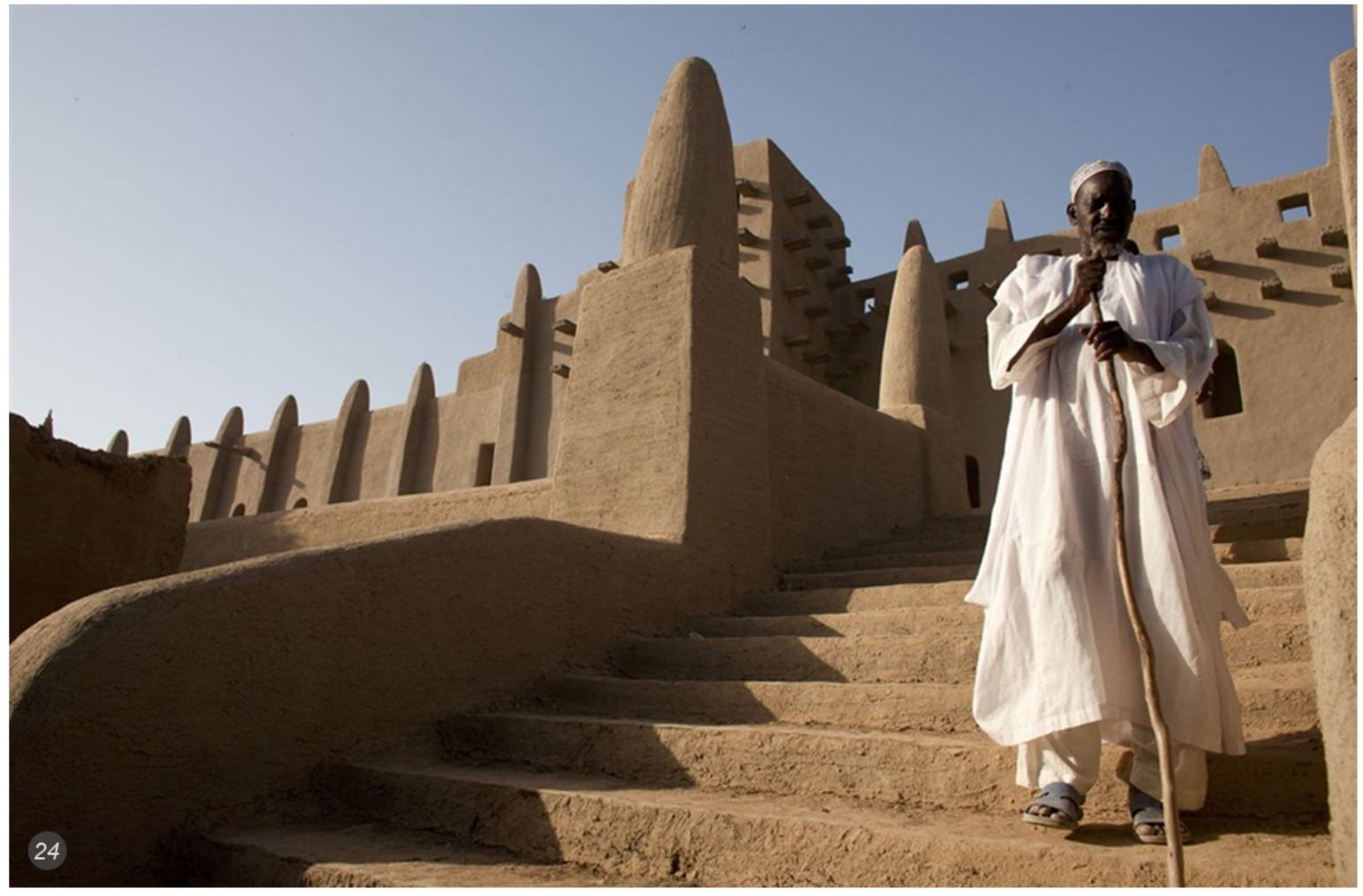

Figure 24 Great Mosque of Djenne, the larget mud-brick structure in the world, Djenne, Mali 


\subsection{Dilemma 2: With The Expansion of Global Construction Knowledge and Power, How Will Architectural Practice Evolve?}

While an engaging architectural response can be beneficial and multilayered, the effects of a global economy and well-established construction industry make proposing local building techniques and material extremely challenging. During the 1980s, Kenneth Frampton, in his writings on critical regionalism, voiced concern over the persistent and universal transformation of the built environment that has resulted from the use of optimized technology in the manufacturing of building elements. This technology results directly from issues of time and space compression; as people, information and goods become more mobile, they are subjected to stronger economic and social competition, which often results in a more poorly produced product. Dana Cuff ${ }^{2}$ specifically addressed contradictions found in the debate of architectural regionalism and architectural localism, being particularly doubtful about Frampton's ideas on critical regionalism at a time when architectural practice is becoming increasingly global.

For instance, the mud-brick buildings in Djenne, Mali, are beautiful, unique and closely tied to the community's local identity (Figure 24). The residents participate in the re-mudding of the mud-brick structures at the beginning of every wet and dry season, engaging with the buildings both physically and spiritually. However, with water being such a scarce and precious resource, these vernacular materials and techniques are being replaced with more "modern" and universal strategies. The concrete houses which have replaced the vernacular structures do not respond to climatic, social or cultural conditions, but returning to mud-brick buildings does not appear to be a viable option (Balbaa, 2007). This is the case not simply because of the scarcity of water but because of the powerful and intransigent position the architects, engineers and administrators have taken in imposing Western strategies without being prepared to re-skill (Habraken, 1998).

2 Dana Cuff, in her discussion "Scales of Practice: Architecture in the Global Economy," 
Kris Olds ${ }^{3}$ analyzed the practices of global mega-projects that often involve the transformation of entire quadrants, even cities, through massive building projects that sometimes displace thousands of people. These projects call into question the ethics of architectural practice when it adversely affects so many people, dilutes local culture and damages local economies.

A successful precedent that answers this dilemma is the pilot project for the participatory process that shaped the design of the Koudougou Central Market in Burkina Faso, West Africa. At the urban scale (global), Koudougou Central Market reinforces and enhances the fabric of a mid-sized town, providing a place for commercial and social exchange. On the level of construction (local), it introduces simple and easily integrated improvements to a traditional material that allow it to achieve its full aesthetic and environmental potential (Figure 26-28).
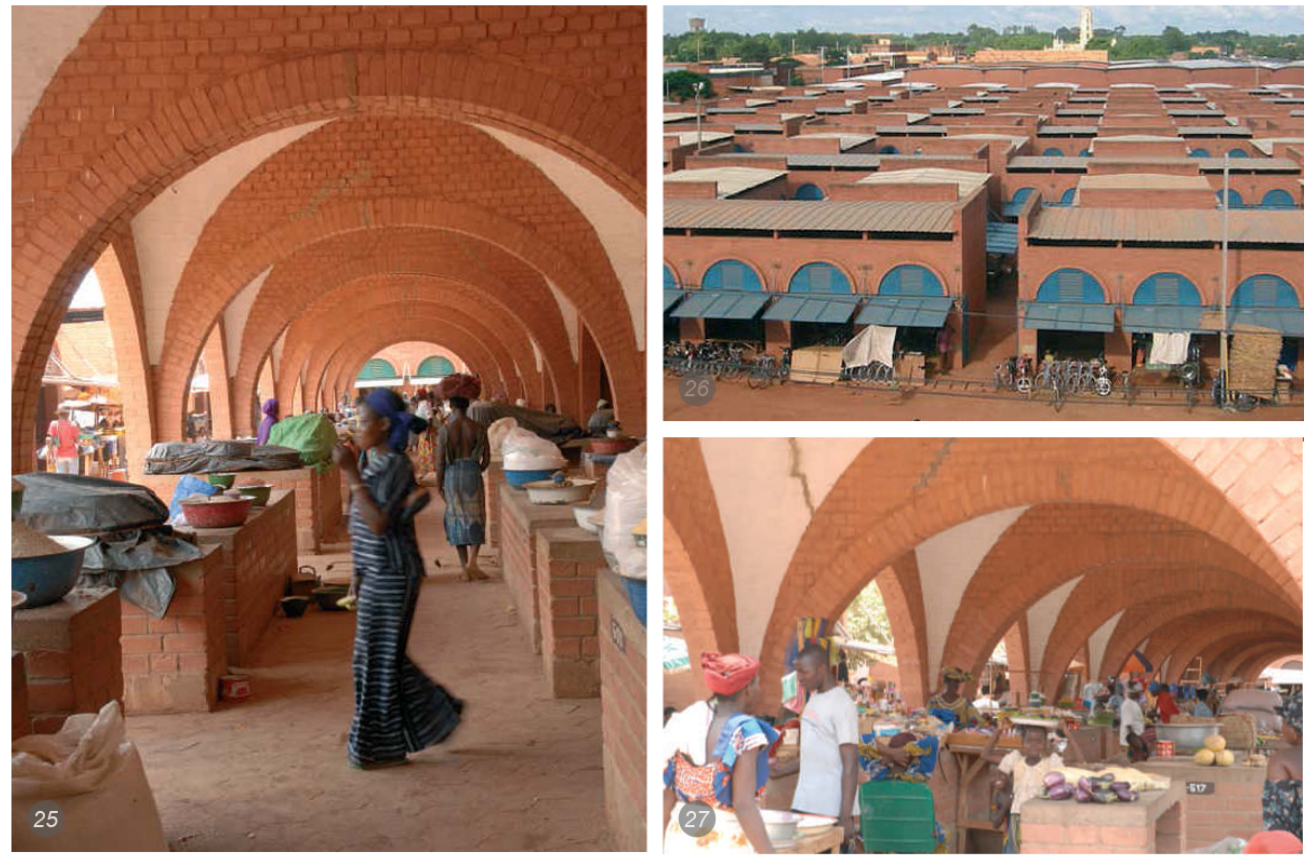

Figure 25, 26, 27 Koudougou Central Market, Burkina Faso

${ }^{3}$ Kris Olds is a Professor of Geography at University of Wisconsin-Madison. His research primarily focuses on the geographical organization of power in relation to contemporary socio-economic and spatial transformations. 
Burkina Faso is being indelibly changed by rapid urbanization. Not long ago, 90 per cent of the population lived in rural areas, scattered across more than 8,000 villages. Now there is a seemingly unstoppable flow of migration to the country's two largest urban centers. In an effort to balance the effects of this rural migration, the government launched the Programme de Développement des Villes Moyennes in 1990. The program's aim is to strengthen the country's mid-sized towns, Ouagadougou, by using commercial infrastructures such as markets as the driving force for sustainable development.

The planned solution for Koudougou Central Market was to provide a very densely populated market, with the maximum number of permanent individual six square meter shops. In total, the new market has provided 1,155 shops, 624 stalls and two administrative buildings, as well as the necessary ancillary services such as public toilets and water taps. The market's internal layout is quite simple and regular. A first orthogonal grid, with rows of shops running east-west along the width of the market, defines the alleys. A second orthogonal grid with shops directed north-south along its length defines the small gathering places. The second grid is interrupted by an open, domed space supported by a series of high arches that contains the stalls. The juxtaposition of the two grids generates a special rhythm that disrupts the high density and repetitiveness of the construction. It also opens up views all along the length and breadth of the market. This organization allows for good air circulation and gives every building the benefit of shade created by the other constructions.

By using stabilized earth for roofs and walls, the market not only demonstrates the superior climatic performance of the local building material, but also shows how humble earth blocks can be used to create a sophisticated pattern language of vaults, domes and arches.

The Central Market is part of a broader local development strategy. It was approached not as a conventional commercial activity, but as a participatory process engaging a wide cross-section of the community. 


\subsection{Conclusion}

In conclusion, cultural globalization is a rapid traversing of ideas, attitudes and values that leads to an interconnectedness and interaction between peoples of diverse cultures. In fact the importance of culture lies in its link between people and their value systems. With such influences from the modern world as standardization, mass production, and uniformity of lifestyle, the diversity and specificity of different cultures and localities is diminishing. Architecture must do more than respond to the evident socioeconomic problems of a site; it must reflect and contribute to the social, spiritual, and cultural contexts. 


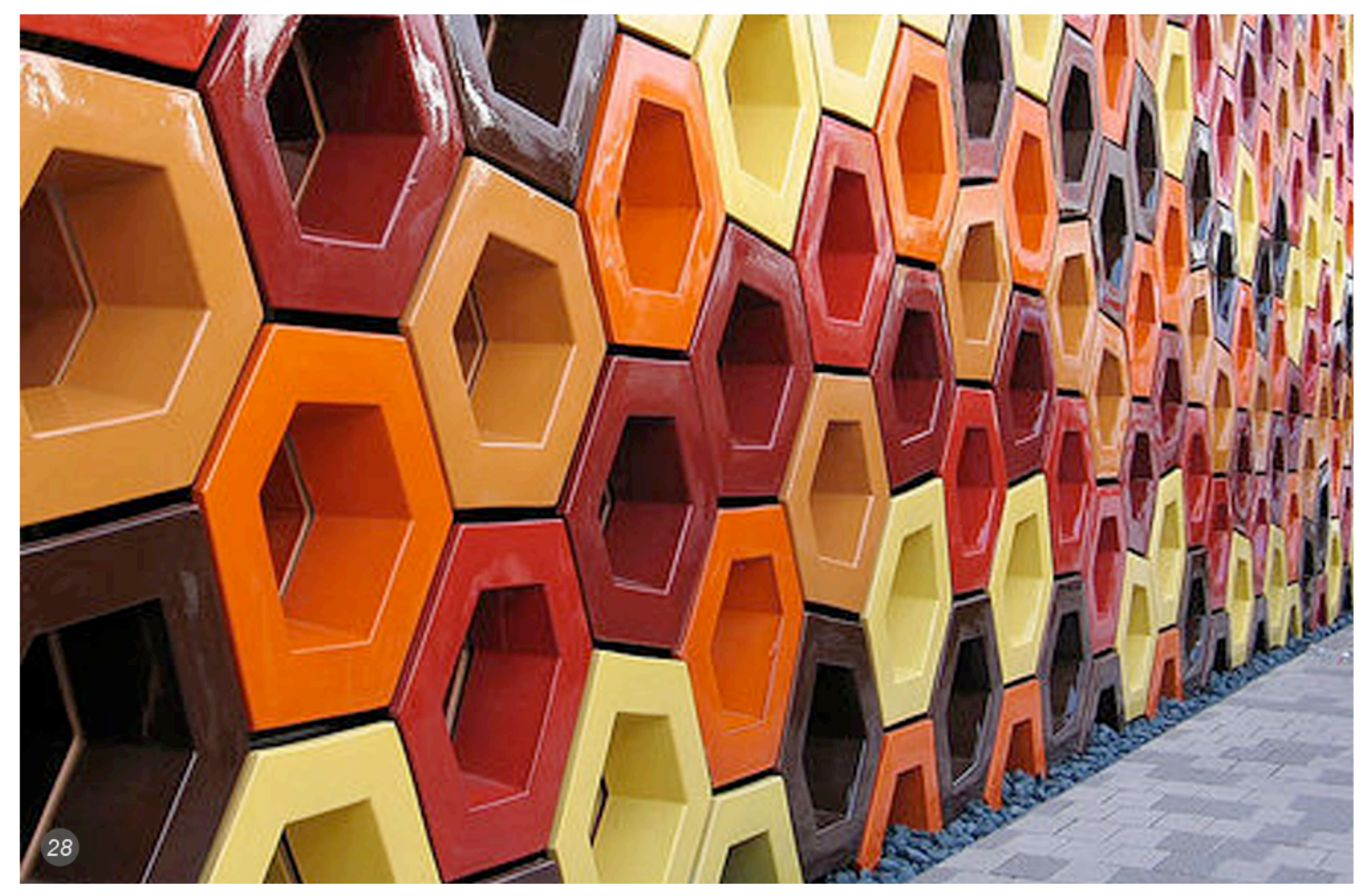

Figure 28 Spanish Pavilion, Designed by Foreign Office Architecture, Expo 2005, Nagoya, Japan 


\section{Culture \& Architecture}

\subsection{The Implications of Cultural History in Architecture}

The word "culture" is multi-layered and extremely difficult to define. The Oxford Dictionary defines culture as "the arts and other manifestations of human intellectual achievement regarded collectively" and/or "the ideas, customs, and social behavior of a particular people or society." What becomes clear is that culture is not clearly definable and can be interpreted in several different ways depending on one's perspective and opinion.

It is hard to understand the relationship between culture and architecture. Entire nations are often defined by a single architectural style, and yet their culture, and the vocabulary used in their local architecture, is far more complex than this simple description would suggest. Cultural biases are often expressed through architectural forms and styles without consideration to an evolving cultural identity or way of life. Culturally responsive architecture must respect the complexities and changing qualities of culture, expressing these traces while allowing for development over time (Figure 28).

In his article "The Cultural Burden of Architecture", Gulsum Baydar ${ }^{4}$ argues that architectural history itself has developed based on Western biases towards certain cultures and social levels, and that as different civilizations evolved in completely different eras, it is difficult to determine when the emergence of culture as an important part of architectural discourse

\footnotetext{
${ }^{4}$ The Cultural Burden of Architecture
} 
occurred. Baydar also suggests that colonization, throughout different moments in history and in geographic contexts, has resulted in the discovery of diverse cultures and their effects on each other; at the moment of colonization, the question of defining architecture shifted from Vitruvius's ${ }^{5}$ notion of the difference between architecture and shelter, to conflicting notions of universal and regional architecture, which created tensions as ideas of "wholeness, continuity, and essence" were integral to the western definition of culture and art. Reinforcement of ethnic and racial hierarchies followed colonization, with the imposition of rigidly defined architectural languages and cultural values; post-colonial ideologies stressed heterogeneous and de-centered cultural categories, which suppressed and classified ethnic groups through a lack of defined cultural identity as opposed to an overly rigid, misrepresented definition of cultural identity. Both definitions of cultural identity can be extremely negative to a group of people and can result in social and cultural isolation.

While architecture can be used to overpower a people, it can also be used to re-establish power through expression of cultural identity and development. Temples, monuments, churches, and cathedrals have been used to represent power for centuries. While most minority groups do not possess the resources for such activities, some have utilized the same strategy to give themselves a voice and a sense of establishment.

For example Louis Kahn's National Assembly Building of Bangladesh in Dhaka is an extraordinary example of architecture being used as tool to establish democracy for the Bangali people (Figure 29-31).

The National Assembly Building sits as a massive entity in the Bengali desert; there are eight halls that are concentrically aligned around the parliamentary grand chamber, which is not only a metaphor for placing the new democratic

\footnotetext{
${ }^{5}$ Marcus Vitruvius Pollio (born c. 80-70 BC, died after c. 15 BC) was a Roman writer, architect and engineer. He is best known as the author of the multi-volume work De Architectura ("On Architecture"). Vitruvius thought that a timeless notion of beauty could be learnt from the 'truth of nature', that nature's designs were based on universal laws of proportion and symmetry. He believed that the body's proportions could be used as a model of natural proportional perfection.
} 
government at the heart of the building but also is a part of Kahn's design objectives to optimize spatial configurations where the supporting programs (offices, hotels for parliamentary officials, and a restaurant) project out of the center volume. The entire complex is fabricated out of in-situ concrete with inlaid white marble, which is not only a modernist statement of power and presence, but is more of a testament to the local materials and values. The sheer mass of the monumentally scaled National Assembly, and the artificial lake surrounding the building, acts as a natural insulator and cooling system that also creates interesting spatial and lighting conditions.
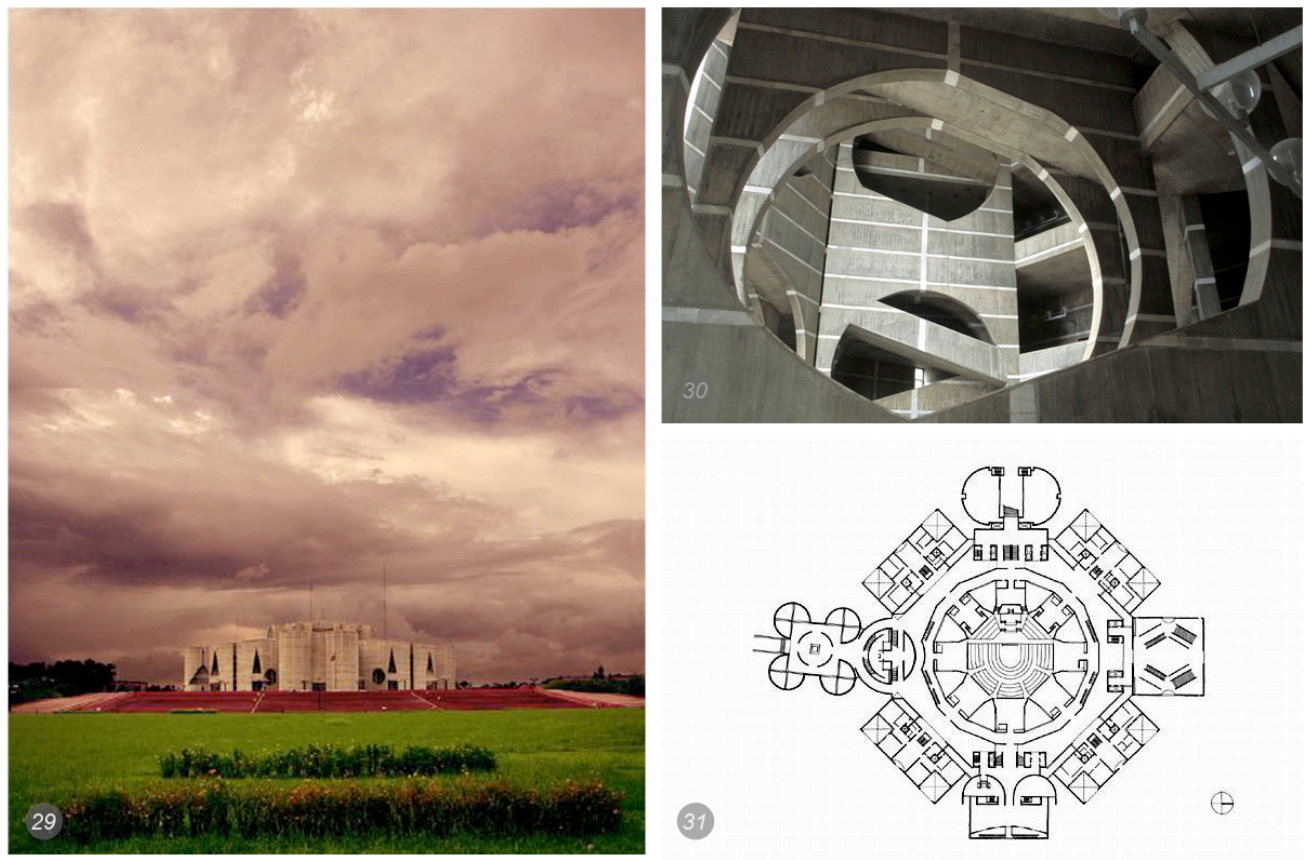

Figure 29, 30, 31 National Assembly Building of Bangladesh, Design by Louis Kahn

The geometric shapes found on the different faces of the façade add a dramatic impact to the overall composition of the building. The geometric shapes are abstracted forms found in traditional Bangali culture that are meant to create a marriage of old and new cultural identities, as well as serve as light wells and a natural environmental control system for the interior. For Kahn, light was an important aspect in the design of a building, not just as a way to illuminate a space, but rather conceptualizing light as a creator of space. 
The National Assembly Building is unique in the sense that it is modernist in principle, but it is a project deeply rooted in its context, the citizens, and Bangali vernacular. With most modern buildings, it can be placed almost anywhere in the world without much fuss, which does not exactly work with the National Assembly. Kahn's designed called for simplistic local materials that were readily available and could be implemented in distinctly similar ways to protect against the harsh desert climate, integrating a modern building into an otherwise non-modern context.

Throughout history, architecture has been used as a tool for displaying power and wealth, with cultural precedents generally being taken from buildings for the privileged and wealthy (Rudofsky, 1964). This not only leads to a misrepresentation of culture, but also can have serious sociological implications due to use of inappropriate design strategies. Egyptian architect Hassan Fathy strove to re-interpret vernacular building strategies and techniques in order to provide adequate housing for Egypt's rural poor. He criticized modern Egyptian architecture for replacing vernacular strategies and architectural styles for a more universal architectural language ${ }^{6}$. He believed that the existing architecture disregarded culture and climate, produced sub-par living conditions, and disconnected the population from its cultural heritage. He contended that implementation of vernacular strategies and techniques would provide more culturally and climatic responsive architecture, while reinforcing cultural identity. A key part of this was the engagement of the public with these built forms, passing on techniques through participating in the building process. While his aspirations were commendable, he fell prey to the issues expressed by Rudofsky in his article "Architecture Without Architects" of setting design precedents on the wealthy.

For his housing proposals for the village of New Gourna in Upper Egypt, Fathy implemented a courtyard house design used by the bourgeoisie of mediaeval Cairo (Figure 32-34). The working class had difficulty accepting these layouts, as they generally could not afford trading usable land for open

\footnotetext{
${ }^{6}$ Fathy, Architecture for the Poor, 1969
} 
space. Public buildings grouped around large squares is a common phenomenon in the Mediterranean context but extremely rare in Upper Egyptian villages. The center of social life in Egypt was commonly the streets themselves, with the winding, narrow streets of New Gourna acting as far more successful social spaces than the squares Fathy provided (Steele, 1988). This demonstrates the importance of understanding the multiple layers of culture and local architecture.

But why is it important to consider the effects of cultural identity and development in architectural projects? The importance of these implications have been brought into question as a result of discussions on critical regionalism in architecture, which have become increasingly influential over the past couple of decades. A regionalist approach would allow groups of people and rural communities the opportunity for self-expression and reinforcement of cultural identity; however, the opportunity for nostalgic referencing and misrepresentation are great and should be avoided.
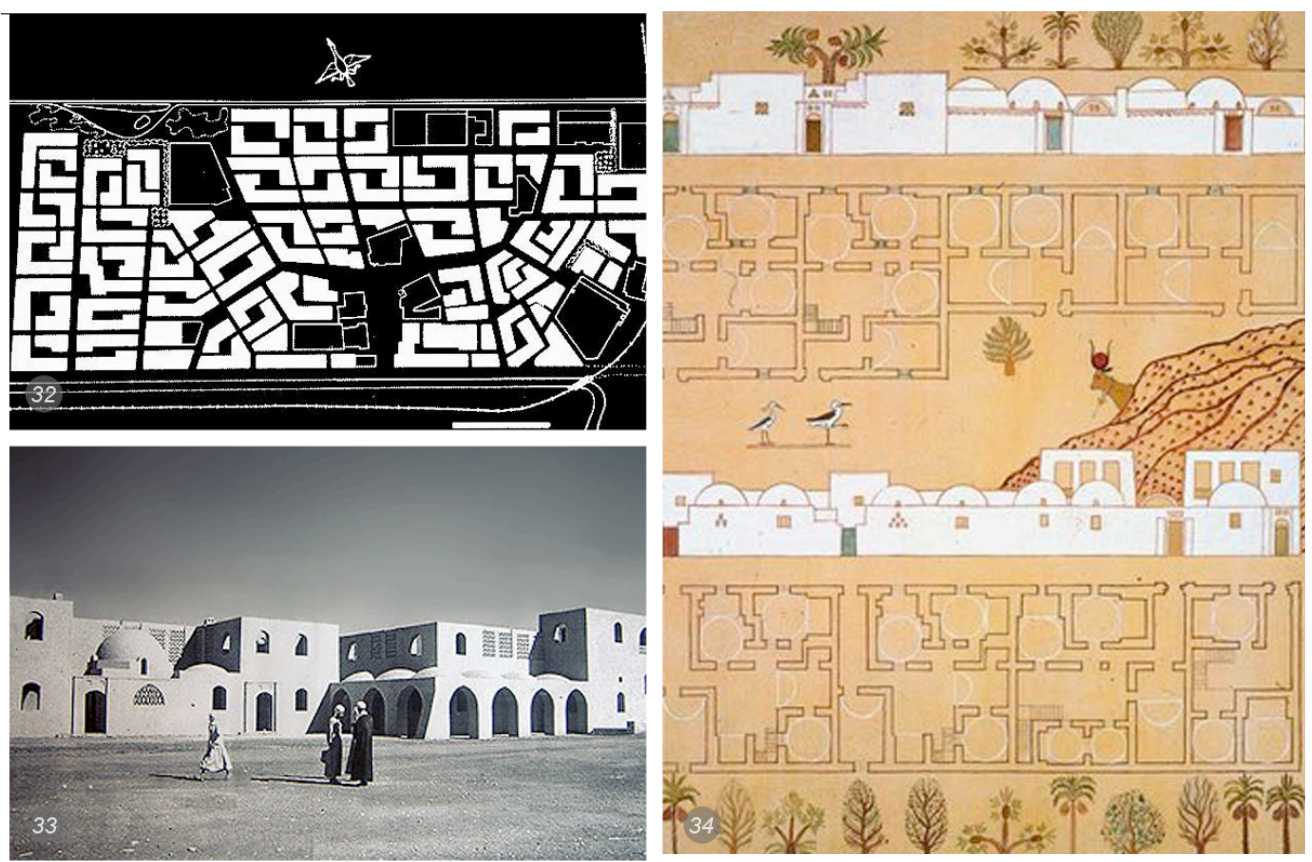

Figure 32, 33, 34 The village of New Gourna, Opposite Luxor, Upper Egypt, 1945-1948 
From the perspective of a designer, one must remain aware of the challenges involved in working with and representing a group of people and recognize one's own biases. With so many complexities regarding culture and its representation, it becomes questionable whether architecture can in fact represent a culture. More importantly, should this be considered a role of architecture? How can the built form contribute to an evolving cultural identity rather than a static representation of a singular vision of culture? 


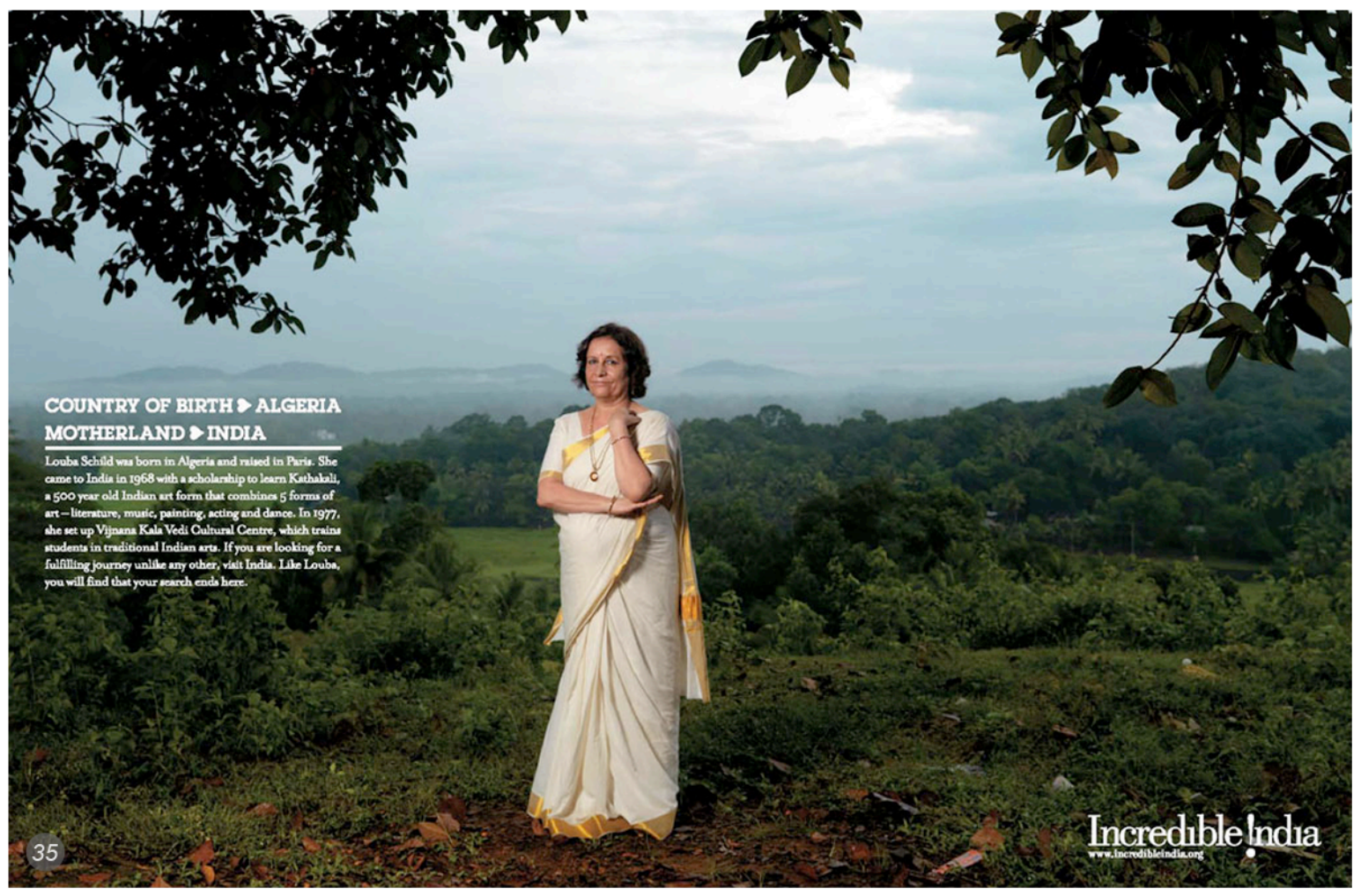

Figure $35 \quad$ India Tourism campaign based on the cultural roots experiences. 


\subsection{Understanding Cultural Roots}

Culture contains elements of the human collective memory, language, beliefs, rituals, myths, and values. These are represented through a variety of art forms and are transmitted from generation to generation. Cultural references and signs are essential to the formation of nation, group, and individual identities. The preservation of cultural heritage is central to protecting a sense of who we are (Figure 35).

A prime example of this is the cultural, as well as social and physical, suppression of African American people. In his book Architecture for the Poor, Hassan Fathy discusses the "rootlessness" of African Americans and how atomization of a people has rendered them nearly powerless and without a sense of cultural identity. Africans were sold as slaves in West Africa and shuffled around to eliminate the unity and power of tribes. Rebellion was next to impossible as the members of different tribes could barely communicate with one another. Families were also separated to further atomize the people. Even after the American Civil War, African American communities largely consisted of shantytowns overrun with poverty and little opportunity for people to gain skills and employment. These conditions were seen as disgraceful and detrimental to the residents. Many citizens, architects, developers and politicians worked to build a better reality for the African American people. While the notion of urban renewal seemed commendable, Fathy explained, "it represented yet a new uprooting of communities whose roots were battered and undernourished. However weak were the ties between neighbors, the process sundered them and forced the individuals to begin all over again in a new, alien, if better physical environment." Fathy argued that the growing social problems, such as a surge in crime, were a result of a lack of sense of territorial identification. The seemingly good intentions of outsiders only exacerbated social and cultural issues and the African American people struggle to this day to ground themselves and gain positive momentum. 
Issues regarding loss of cultural identity and disengagement with community and heritage are common effects of outside influence. The effects of a global economy and a universal architectural language are especially conflicting in rural communities, such as Native reserves, where poor populations struggle to maintain cultural identity and adequate living standards (Steele, 1988). It is an undeniable fact that outside influences will continue to shape these communities, making them more dependent on outside aid and diluting distinctions in culture. The dilemma arises in that these communities will lose autonomy, self-sufficiency and connection with their own culture that has supported their way of life for generations (Balbaa, 2007).

Responding to these issues is extremely challenging. In his publication "Regionalism within Modernism" Ozkan (2007) discusses the opportunities and challenges of vernacularism and neo-vernacularism. He explains that although some of Fathy's aspirations were noble, many of his projects executed in rural contexts were unsuccessful. This was largely due to Fathy's uncompromising ideals and the "distorted aspirations and values" the locals held towards contemporary design. Ozkan describes this reinterpreted take of vernacularism as neovernacularism, which is most commonly seen in touristic applications as it reflects a certain universally accepted image of local culture. Pallasmaa (1988) criticizes this approach in his essay "Tradition and Modernity" as it often applies one-dimensional, nostalgic references of vernacular forms in order to create a "sense of place." The issue with this strategy is that it assumes that culture is static and of the past; it is something to be referenced. 


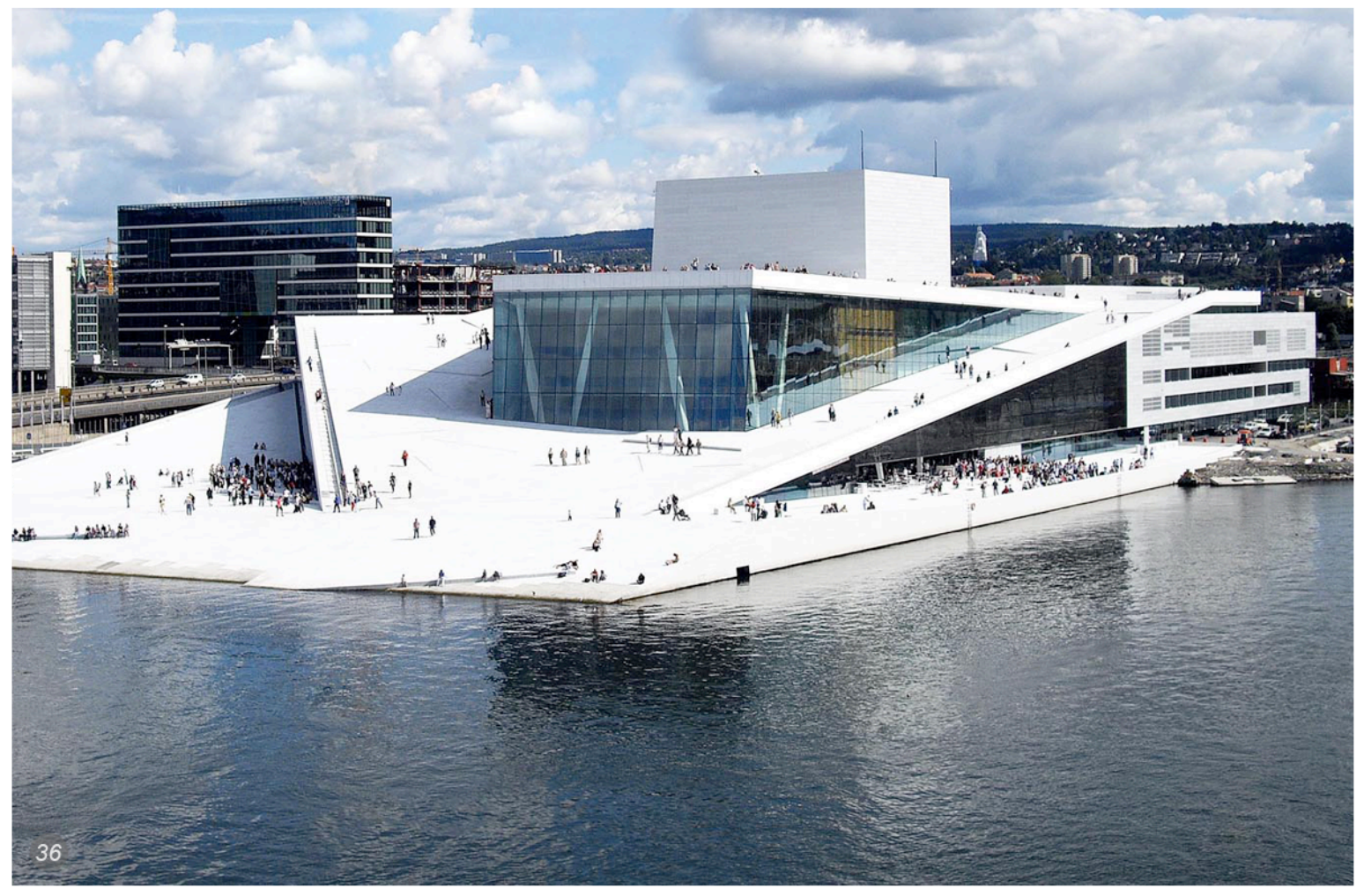

Figure 36 Oslo Opera House, Designed by Snohetta 


\subsection{Role of Architecture with Respect to Culture}

A single work of architecture cannot possibly define an entire people and their history, and yet this is often the result of works by well-known regionalist architects. Therefore what is the role of architecture in defining and reflecting culture?

According to Ozkan (2007), the role of architecture is to respond to cultural issues through extracting qualities of a building into a newly synthesized design (Figure 36 ). He describes the challenges involved in this "abstract regionalism" approach as an attempt to "define, in terms of design elements, the prevalent culture of the region concerned," which he contends is a "long, tedious, and sometimes endless devotion to an ideal." He also claims that "the line which separates a solemn, praiseworthy, regionalist achievement from a worthless pastiche or a pot-pourri of the past is very thin and delicate" (p.109).

The concerns brought up by Ozkan, Eggener, Frampton, Pallasmaa, and other architects point to the challenges of reflecting or reinforcing culture through architecture. They also question what the role of architecture is with regards to cultural identity and the undeniable presence of biases. While architecture can reinforce biases and singular definitions of culture, it can also establish a new narrative of the past and reframe our understanding of current cultural and social conditions.

The dilemma of re-interpretive narrative in architecture and how it affects our understanding of the past is explained by Collier: "The story never stays the same; every time we tell it we reinterpret it in the light of new experience.

Sense-making happens not just by retelling the past so as to integrate it into the present, but by interpreting both past and present in the light of understandings of future direction and purpose." 


\subsection{Conclusion}

The fluid quality of culture and our interpretation of it make it almost impossible to represent it in a single architectural effort. For this reason, the focus of this thesis is to discuss the opportunities that exist in reinforcing cultural identity through architecture and possible strategies that can be implemented. Therefore the objective is to build a more complex relationship between the people and the architecture that fulfills needs as well as desires. So what is most important in this strategy is to understand the uniqueness of local culture and open it up to a global cultural dialogue. It is therefore important to work closely within the culture to enable people to actively engage in an architectural response, thus reinforcing a connection to their heritage as well as their community. 


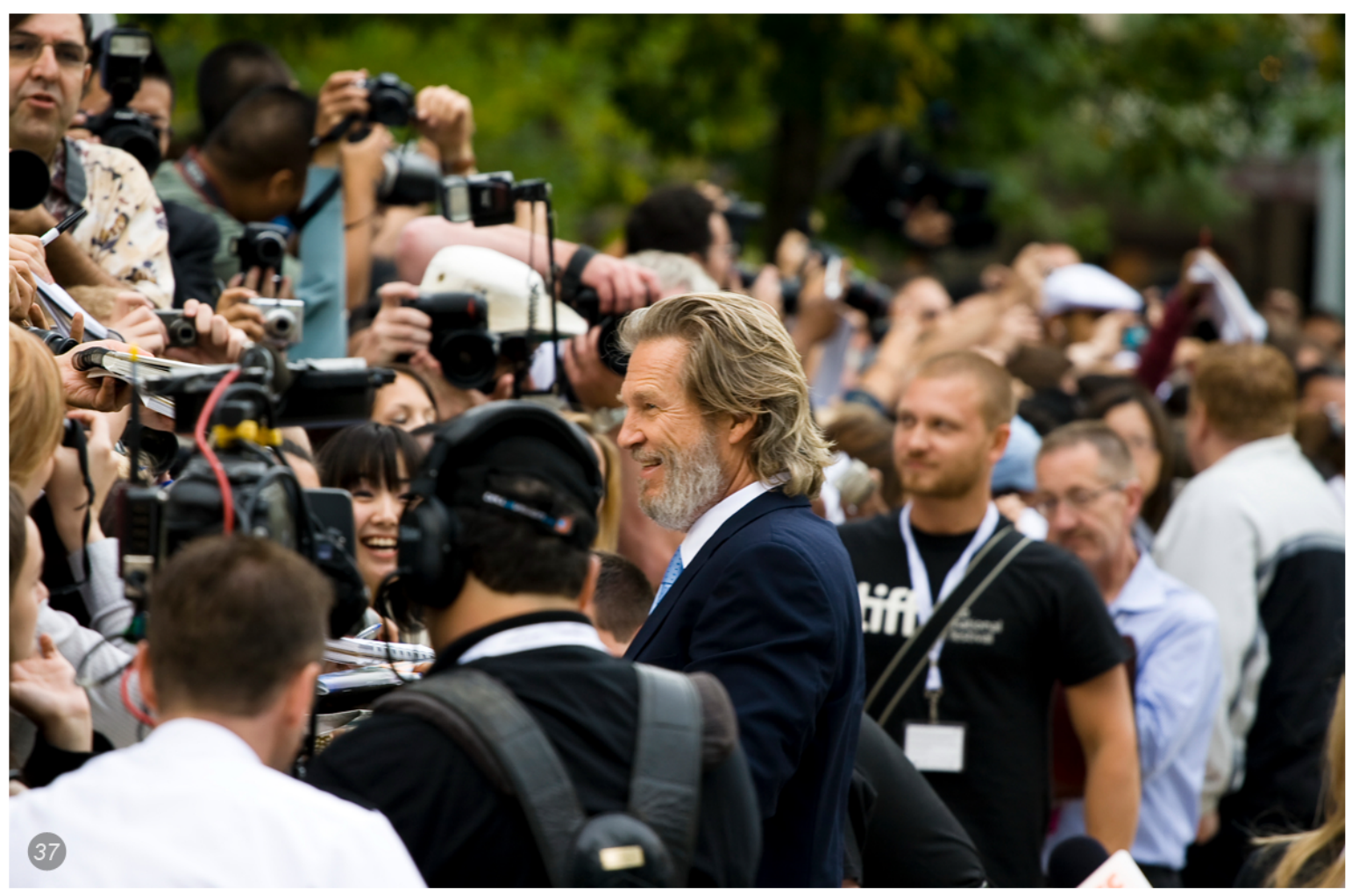

Figure 37 Jeff Bridges at the premiere of "The Men Who Stare at Goats" at the 2009 Toronto International Film Festival (TIFF). TIFF continues to achieve their primary objective by bringing together a remarkable diversity of local, national and international films and personalities to the delight of enthusiastic audiences. 


\section{Toronto \& Globa:local Architecture}

\subsection{Introduction}

It is well known that Toronto is a multicultural city that welcomes people from all over the world. Its vision focuses on building a cultural infrastructure that is community driven and neighborhood focused. It envisions strengthened arts, culture and heritage organizations, and a broadly distributed range of opportunities for citizens of all ages and backgrounds to participate in a wide variety of cultural activities. Toronto has also provided a collaborative platform for new partners from the community and business spheres to build strong cultural institutions, to develop complete sustainable communities, and to promote new forms of wealth creation (Figure 37).

The purpose of comparing Toronto to a glob:local architecture phenomena is to articulate a long term vision for local cultures to find their ground and launch global initiatives, and develop a list of actionable recommendations and an implementation for architects, As well as developing comprehensive knowledge of the arts, and cultural resources in Toronto and make it accessible to the local community which ultimately result in identifying local momentum. 


\subsection{Why Globa:local Architecture Suits Toronto}

Toronto is home to some of the world's most compelling local cultures. They give a depth and richness of experience to the city that is rare and special. They imbibe places with a sense of uniqueness and distinctness. For instance, there is the diverse cosmopolitanism of Kensington Market, the offbeat edginess of West Queen West, and the ethnic authenticity of Greektown or Chinatown.

Globa:local architecture benefits communities by harnessing their cultural resources and creative potential to achieve social and economic benefits that make them more livable and attractive places to residents, newcomers, and for investment. Figure 1 shows how cultural planning is connected to many of the important processes of building complete sustainable communities. There appears to be a growing acceptance throughout Ontario of culture's role in renewing local economies.

As a case study, I looked at Kensington Market (Figure 38) to understand how it has become a magnet for global attention.

My first impression of the neighborhood was that the visitor could easily forget that they are in the middle of one of the largest cities in North America. For sure this neighborhood feels like a distinct small town. Unique coffee shops, clothing shops, a print shop, a musical instrument store, a massage therapist and a bar are key ingredients in this diverse place.

Kensington Market has become a fully sustaining neighborhood for the artistic community, yet it also brings economic stimulants for the city at large by hosting different annual festivals and events. Renowned for its diversity, Kensington Market began as an open-air market for the Jewish community during the early 20th century, and then welcomed successive waves of 


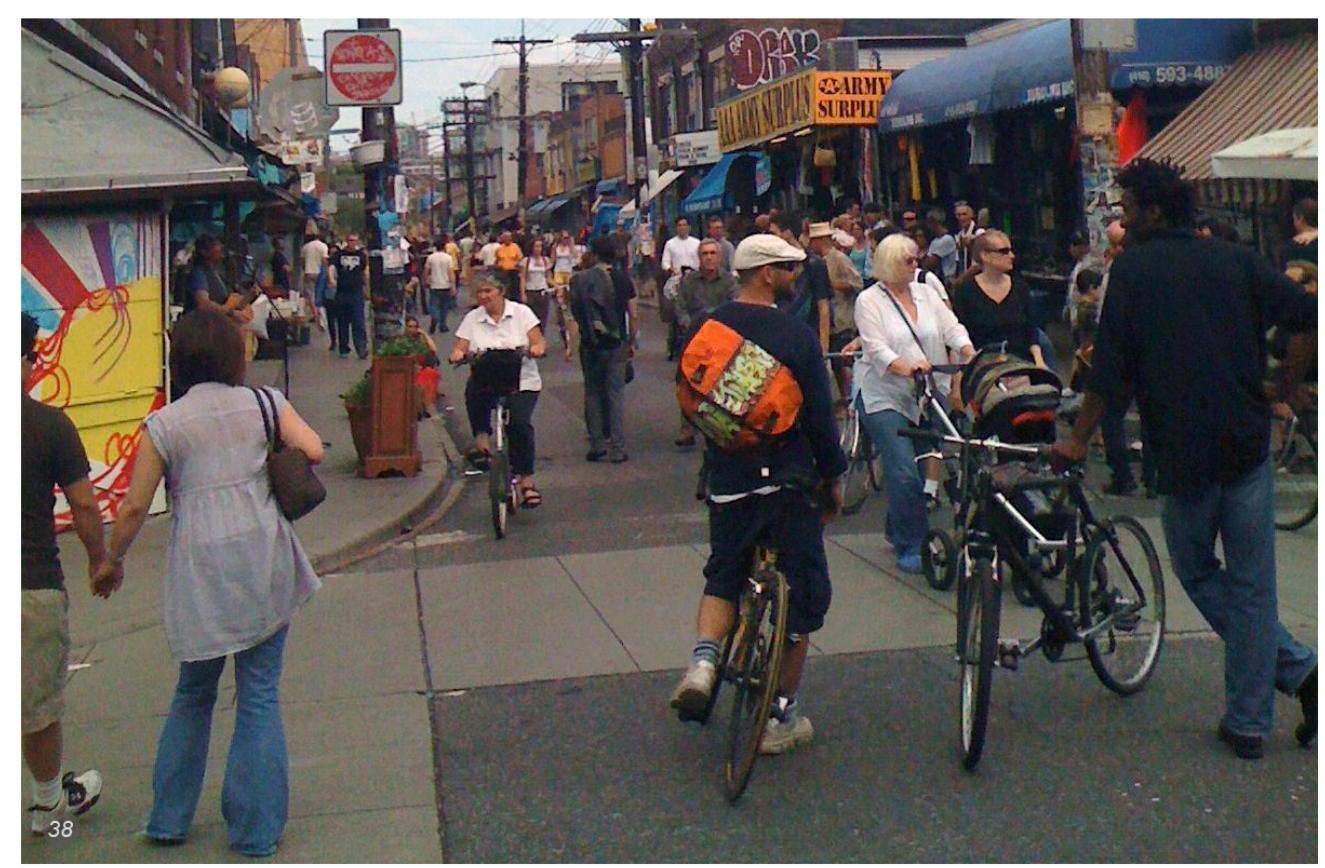

Figure 38 Kensington Market on a Sunday morning.

Portuguese, Caribbean, and Chinese newcomers. During the early 1980s, the Market's cheap rents and permissive lifestyle made it a haven for the punk rock scene. Though rents and house prices have risen in recent years, the Market has remarkably resisted development pressure and the infiltration of chain stores. This is the neighborhood that seemingly won't gentrify and without them, Toronto would be less vibrant, less interesting, and less critically self-reflective.

Local cultures do more than help Toronto capture local and tourist dollars, they also add value to the city's production of creative and cultural goods (Figure 39). They do so by creating special spaces of intense communication, creativity, interaction, and collaboration. The presence of such spaces improves the overall quality of the creative work produced in the city. This improvement may depend on a number of special dynamics that local culture mobilizes. 


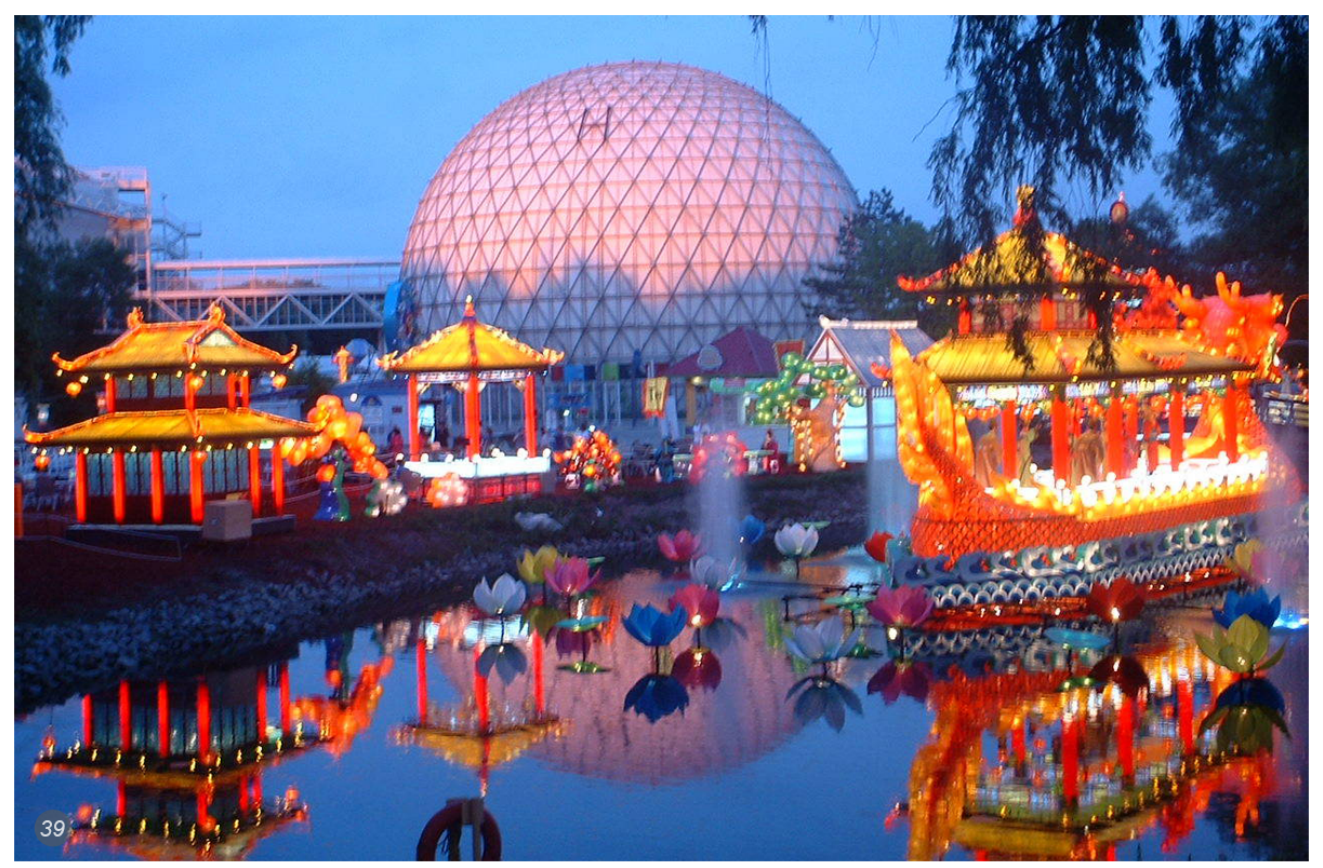

Figure 39 Chinese Lantern Festival Pavilions with Cinesphere at Ontario Place on Toronto's waterfront has evolved into cultural exchange event that is full of cultural content and commercial value.

- $\quad$ Peer support

Local culture members appreciate and cheer on novel, risky ideas, even when they don't work. In a local culture, people are encouraged to try things they would not have done otherwise. They are often experimental spaces that are highly tolerant of untested expressive possibilities, creating a proving ground where new styles are developed before they are exported to a broader market.

\section{- Idea and technique sharing}

Local culture members typically share a common sensibility as to what is important. They want to learn from each other. Any new technique or style (of music, fashion, recording technique, programming technique, etc.) is shown off and quickly circulated and refined. 
- Collective success

Most artists working in a local culture earn relatively modest incomes through their artwork. A few bubble to the surface and enjoy commercial success. These are products of countless conversations and interactions with others artists, musicians, performers, critics, and the like. They depend on the atmosphere of the scene.

\section{- Place branding}

Work produced within a local culture becomes invested with the particular character and aura of that local culture. Music created in Toronto's indie rock local culture has a special value that similarsounding music created elsewhere might not have. This creates a base of cultural industrial production that cannot easily be reproduced or outsourced elsewhere. 


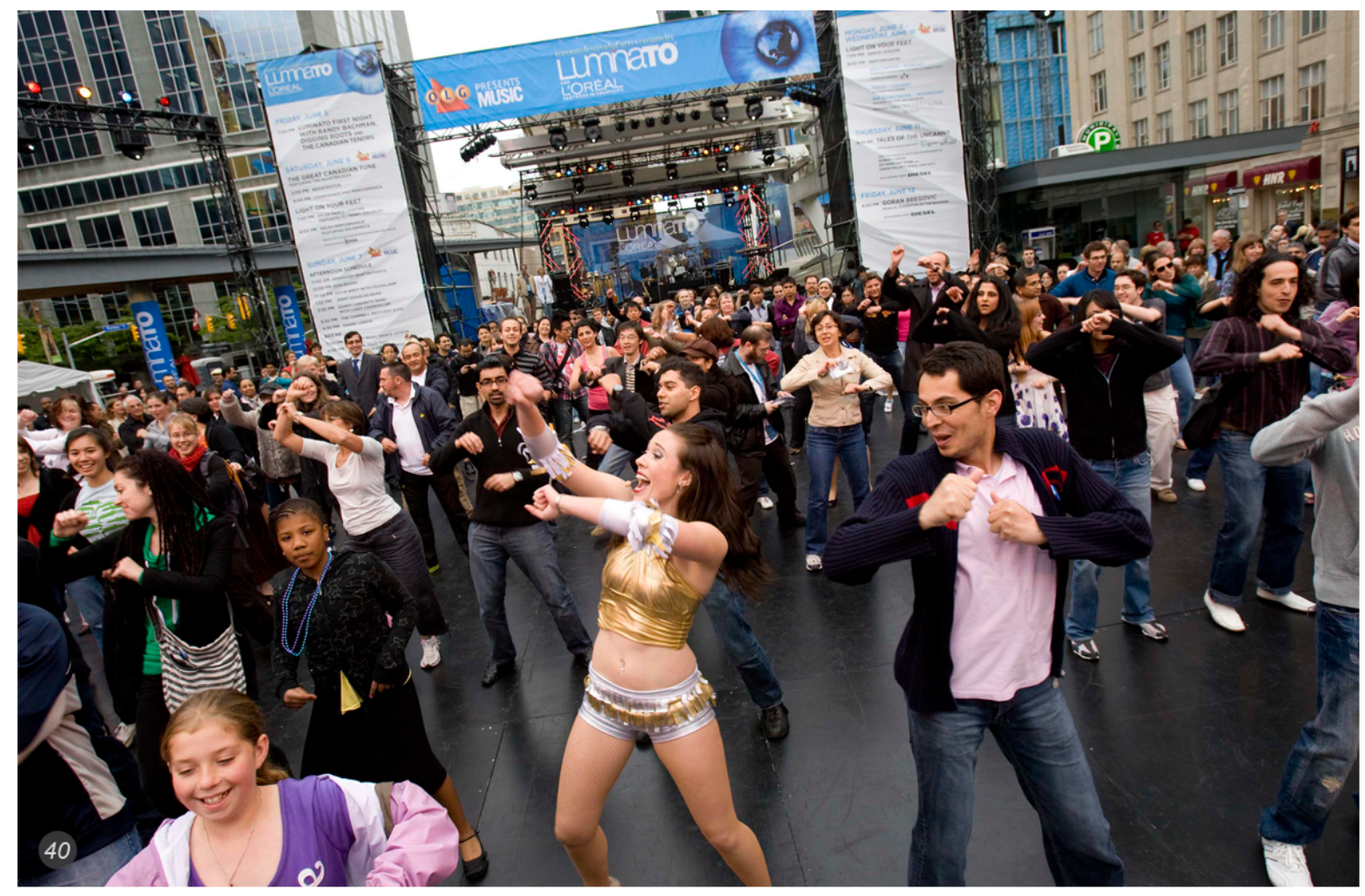

Figure 40 During Luminato festival, Toronto's public spaces become open canvas for street artists. In the above image Yonge-Dundas square is used for Luminato Festival Light on Your Feet Dance Project. 


\subsection{Importance of Cultural Scenes}

Local culture is working but it is a special kind of work. It involves stimulation, critique, expression, encouragement, creativity, doubt, perseverance, vulnerability, spontaneity, daring, discipline, and much more (Figure 40). Such qualities are difficult to sustain alone. They can be enhanced by social contexts that welcome the inevitable risks and the precarious rewards endemic to cultural work. How can we identify places that possess these sorts of social contexts?

Places where local cultures use is usually in sufficient density, depth, and intensity. Vibrant local activities bring tremendous social and economic benefits to the local context. They need to be preserved and grown.

As Mentioned before, there is no single formula for a successful cultural scene, however key characteristics include:

\section{- An amenity-rich environment.}

Cafes, restaurants, galleries, theatres, festivals, shops, music venues, bars, dance clubs and nightlife are the most obvious expressions of cultural vitality. But a healthy day life, including grocery stores, fruit stands, convenience stores, hardware stores, and daycare centers, hairstylists and clothing shops are a crucial part of a scene's infrastructure.

\section{- Committed supporters.}

A local culture is only as strong as the people who are a part of it. These may include artists, local businesses, audiences, community groups, residents' associations and politicians.

\section{- Distinctive experiences.}

Vital local cultures give a sense of drama, authenticity, and ethical significance to a city's streets and strips. A neighborhood with a vibrant culture can be a theatrical place to see and be seen, an 
authentic place to explore and affirm local, ethnic, and national identity, an ethical place to debate common values, traditions, and ideals.

\subsection{Importance of Local Nodes}

Vibrant local nodes give a unique buzz and energy to a place, offering consumers valuable experiences difficult to acquire elsewhere (Figure 41). This in turn creates local jobs, attracts and maintains skilled residents, and increases local spending. Below are a number of factors involved in creating these nodes.

\section{- Import substitution}

Where there are distinctive local cultures, spectators are more likely to spend their dollars locally rather than on imported CDs, DVDs, books, magazines, clothing, or other services.

\section{- Demand creation}

Vibrant local cultures do not simply substitute for already imported goods and services. They can generate different interests among a wider populace for new styles of music, fashion, dance, cuisine, drinks, and art.

\section{- Use of local services}

Sustaining a strong local culture is labor intensive. Restaurants, theatres, galleries, music venues, and the like utilize numerous local suppliers and rely on a local labor force. A high proportion of the services they consume flow immediately into local employment.

\section{- Scene producers are scene consumers}

The people who make the local culture are also active participants in that. Musicians typically attend one another's shows, as do artists and actors. Where scenes are dense and interconnected, every dollar spent at one performance will often circulate through many more, 


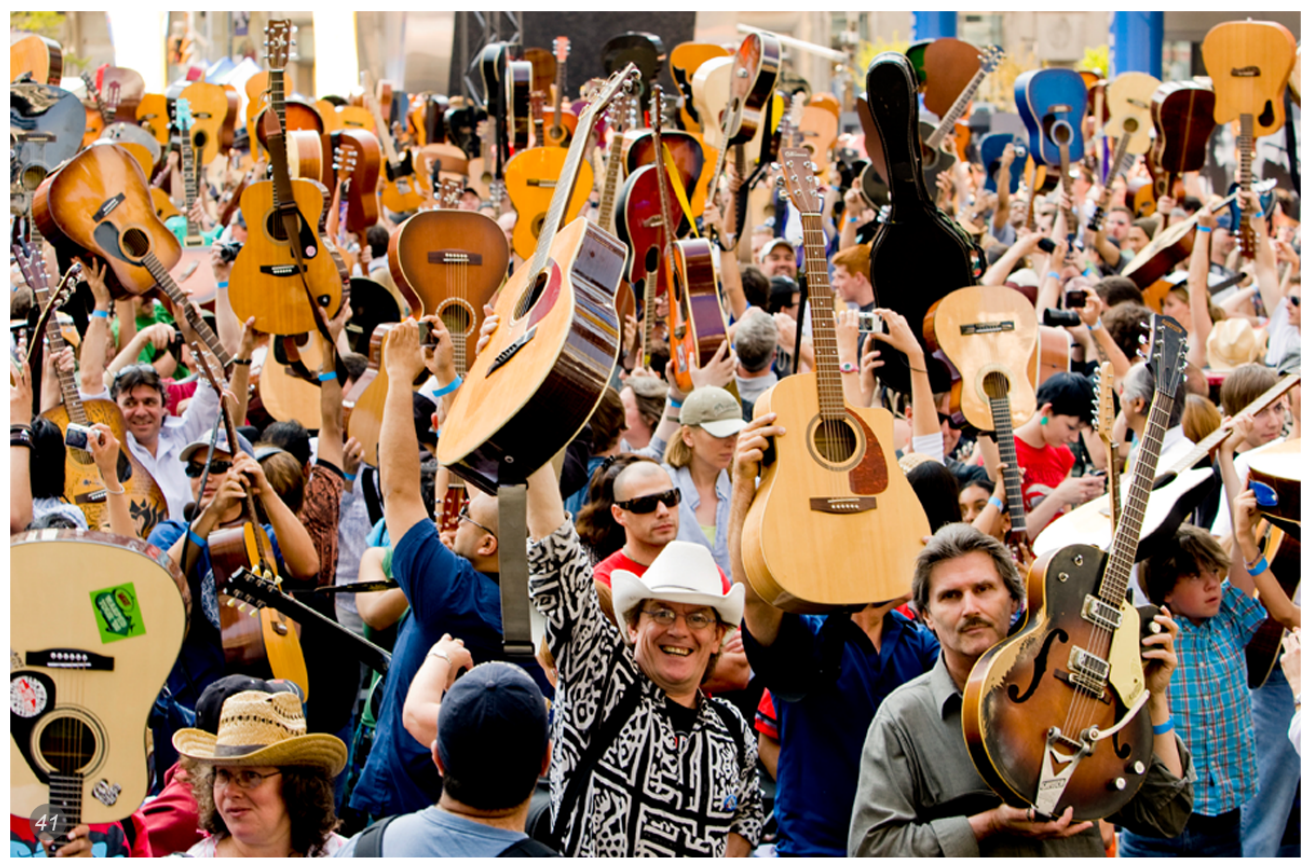

Figure 41 During Luminato's Great Canadian Tune last summer 1,623 gathered to play Neil Young's Helpless in Yonge-Dundas Square. Photo courtesy of Luminato Festival

multiplying overall employment and expanding the available avenues for cultural consumption.

\section{- Talent attraction}

Entrepreneurs who choose to locate in and near local cultures bring their companies. In their efforts to lure talented employees and attract top university graduates, business recruiters often feature local theatres, museums, music performances, promenades, waterfronts, and arts and cultural periodicals. Strong scenes provide amenities and consumption opportunities that attract skilled workers, managers, and entrepreneurs.

\section{- Tourist and retiree attraction}

Vibrant local culture can be important tourist destinations. They showcase the city itself as a kind of perpetually developing live theatre. Visitors are more likely to make repeated trips. Retirees who choose to live in downtown condominiums near bustling scenes bring their retirement incomes into the local economy. 


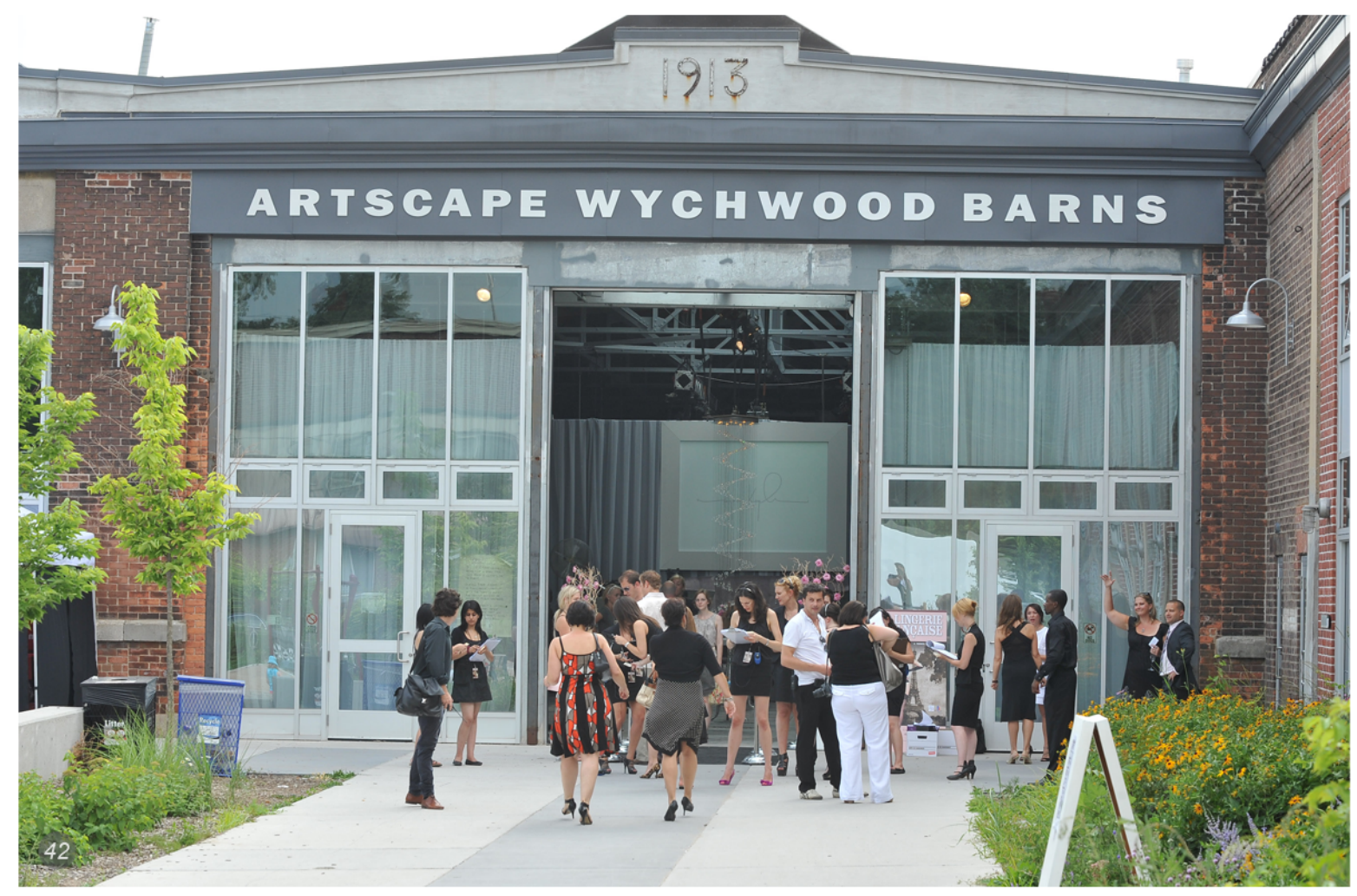

Figure 42 The vision of the Artscape's Wychood Barns is to make a year-round hub of activity that engages the many communities. 


\subsection{Guiding Principles}

This study used the following guidelines to identify how local cultures and activities in a community can be used to achieve global objectives. This section draws from established best practices in globa:local architecture and is guided by five principles:

\subsubsection{Creating Quality Places}

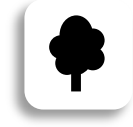

Urban planning practice has increasingly come to regard cultural vitality to be as essential to a sustainable society as social equity, environmental responsibility, and economic viability. This four-pillar model of sustainability has gained considerable profile and currency in Canada, Australia, New Zealand, and Europe in recent years ${ }^{7}$. The four-pillar approach recognizes that a community's vitality, quality of life and social, economic and physical health is closely related to the vitality and quality of its cultural engagement, expression, dialogue, and celebration. Increasingly, governments and arts organizations are recognizing the instrumental potential of the arts and culture in social, environmental and health policy. There is a growing body of international policy which addresses the role of the arts in combating social exclusion experienced as a result of aging, poverty or lack of opportunity. In Toronto, Artscape's Wychwood Barns (Figure 42) offer concrete evidence that the potential synergies between the arts and culture and the environmental movement are leading trends in creative practice and cultural infrastructure development.

\subsubsection{Creative Places}

The Creative City "movement" emerged in the late 1990s and crystallized in 2000 with the publication of "The Creative City" ${ }^{8}$. A response to global

\footnotetext{
${ }^{7}$ The fourth Pillar of sustainability, Jon Hawkes for the Cultural Development Network (vic), 2001

${ }^{8}$ The Creative City: A Toolkit for Urban Innovators, Charles Landry, 2007
} 
urbanization $^{9}$ and the challenges of responding effectively to the problems faced by cities, the Creative City movement has sought to mobilize the benefits of urban life "buzz, interaction, trade, unexpected delight..." to create the sorts of places people want to live, supported by institutions that are collaborative, flexible, democratic, innovative and creative. Culture and creativity move "center stage" in this analysis with a recognition that cultural resources are the raw material of cities, and creativity is the essential ingredient for innovation. In the Creative City, culture and creativity work holistically and are integrated across a full range of institutions and services to develop cities with a sense of place, identity and belonging.

Outside Toronto's downtown core, the suburban built form dominates. The very recent growth of the city is reflected in a limited supply of dense, layered urban environments that creative communities tend to cluster in and that artists and creative entrepreneurs are drawn to as work and/or living space. The challenge in Toronto, as in many suburban contexts, is to nurture a critical mass of arts and cultural activities and facilities and a density of relationships and networks to support the evolution of a rich cultural ecology. So the globa:local architecture in Toronto and the region reflects the desire to animate the local cultures within the city, especially in the downtown periphery, and to improve the quality of urban design.

So the intention is to focus on the potential local momentum and its streets, sidewalks, buildings and other public spaces to identify how it can foster a healthier, more social and more economically viable environment.

This study identifies one of the potential cultural nodes of Toronto. It identifies opportunities to recognize existing concentrations of cultural resources, and identifies policies that can help reinforce them.

\footnotetext{
${ }^{9}$ In 2008 for the first time more than $50 \%$ of the world's population ( $3.3 \mathrm{bn}$ people) will live in cities and the United Nations Population Fund predicts that this will rise to 5bn by 2030
} 


\subsubsection{Strengthening Social Cohesion}

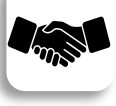

In Canada, Australia and across Europe the historical policy belief around which lawmaking and values have been framed is Multiculturalism.

Multiculturalism focuses on protecting and celebrating diversity of language, belief and cultural traditions and practices, and on equality of opportunity and the respect of differences. In Canada this has been enshrined in policy and legislation since the early 1970 s and is a defining feature of Canadian identity at home and across the globe.

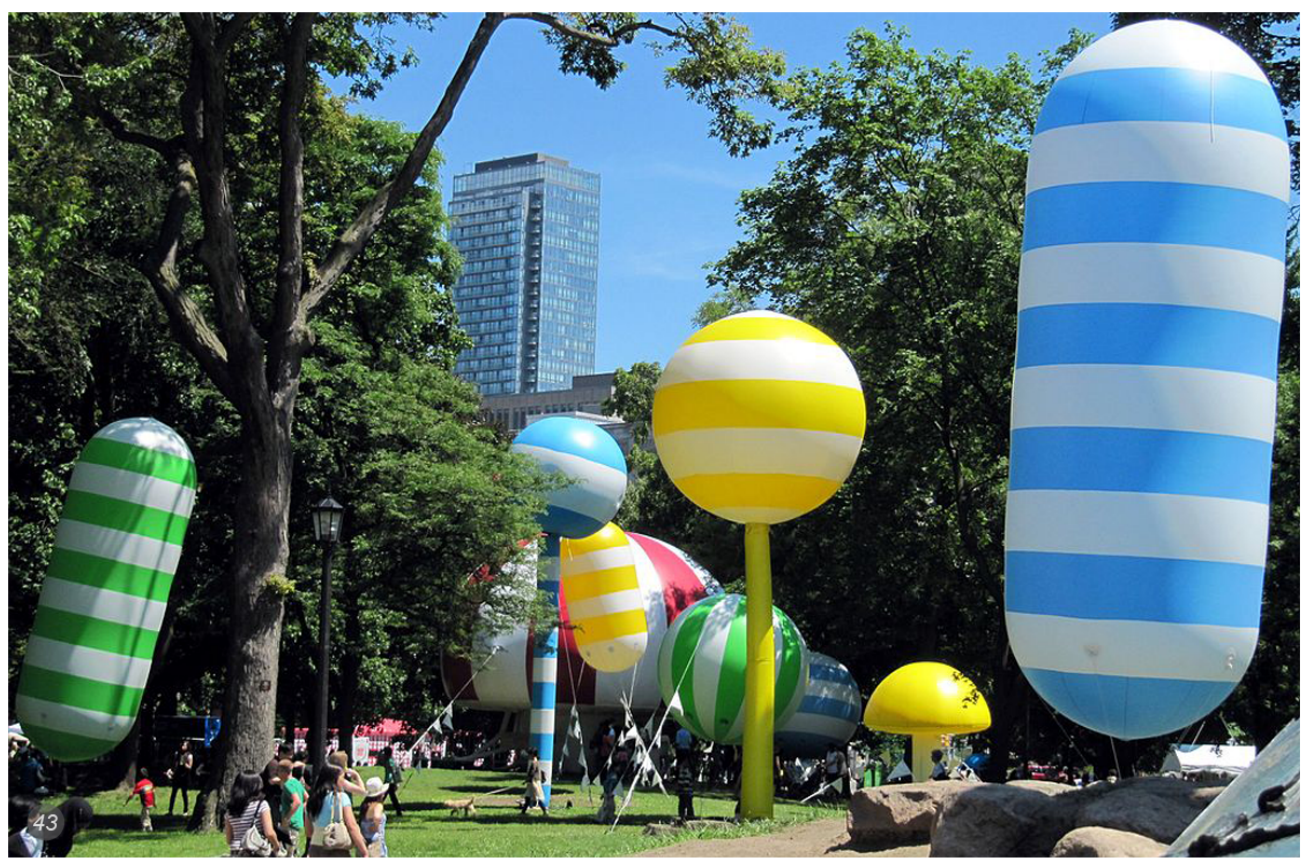

Figure 43 Wish Come True Festival 2010, Photo courtesy of Luminato Festival

As a cornerstone of Canadian federal, provincial and local policy, multiculturalism plays a powerful role in the experience of many of Canada's more diverse cities. Toronto's approach exemplifies the benefits of celebrating ethnic and cultural differences. Greek Town, Chinatown, Little Italy, Korea Town, Little India and so forth are all powerful reflections of the diverse communities and cultures in the city and add to its character and quality of life. 
The concept of Social Cohesion has emerged in recent years, most powerfully in Europe, in response to the challenges faced in a number of European states where multiculturalism has been seen to encourage the evolution of culturally and spatially distinct communities leading parallel lives. A socially cohesive place emphasizes interaction and the exchange of ideas between different cultural groups and focuses on a proactive engagement, mutual exchange, and reciprocal understanding and learning. It seeks to build a "diversity advantage" economic prosperity and social cohesion ${ }^{10}$. Evidence suggests that arts and cultural innovators have a key role to play in developing Social Cohesion.

Toronto's citizens not only value the city's cultural diversity and recognize it as the defining feature of their identity, but also that they want to see a significantly greater manifestation of that cultural diversity in their experience of the city and its built form. Developing an effective response to cultural diversity is highlighted as a priority in existing library, heritage and arts and culture plans in Toronto.

With a focus on the development of the public realm and built form, there is a clear acknowledgement of both an opportunity and a need to develop a more comprehensive approach across a range of arts and cultural service areas. Strengthening social cohesion offers a powerful lens with which to consider the transformation of civic culture and institutions, public spaces and the built form of cities, approaches to economic development and entrepreneurship, and education and training in intercultural cities. This study supports measures that encourage a broadly distributed cultural infrastructure and opportunities for residents to travel inside the city; experience and learn from the cultural offerings of different communities and develop a stronger sense of shared identity across the city.

\subsubsection{Economic Activity}

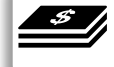

10 The Intercultural City, Planning the Diversity Advantage, Phil Wood and Charles Landry (2007) 
The cultural and creative sector has been recognized worldwide as critical to the economic competitiveness and overall prosperity of cities. Situated within the broader knowledge based economy, the cultural and creative sector is distinct in its generation of value primarily from the symbolic, aesthetic or artistic nature (intangible) of their products rather than solely utilitarian functions (tangible). They not only contribute toward the economy directly (Figure 44), but also have an increasingly critical role in adding value to other sectors of the economy ${ }^{11}$.

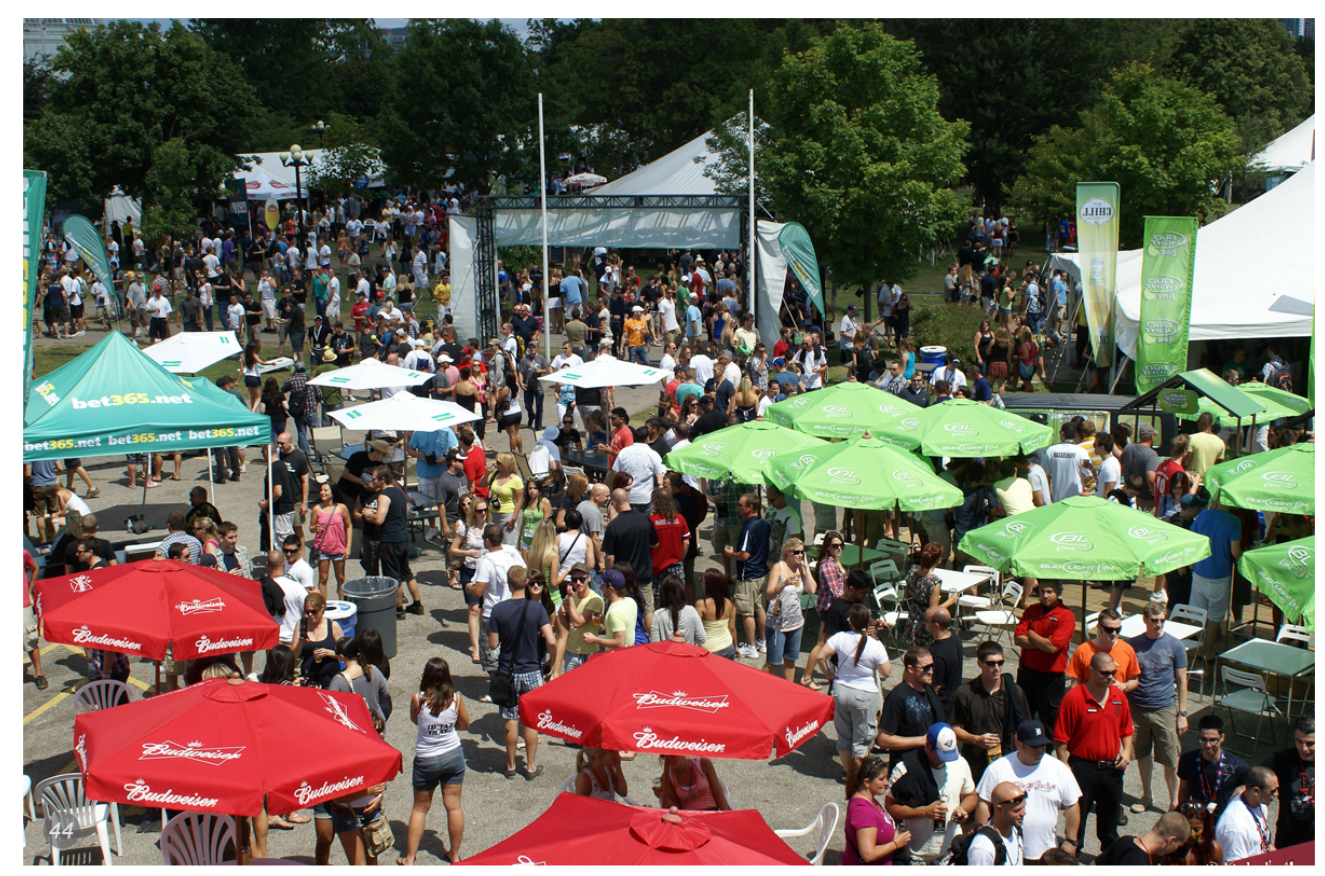

Figure 44 17th Annual Toronto's Festival of Beer, which takes place at Bandshell Park at Exhibition Place, Toronto

Across Canada and internationally, research confirms that creative industries are dominated by micro enterprises and self employed workers, a small number of medium sized firms and very few large firms. Many of these creative workers wear a number of hats and tend to live and work in close proximity to each other. Creative and cultural workers often move between different creative and cultural sectors and between private/commercial, subsidized and not for profit sectors. Their flexible, contract-based work style

\footnotetext{
11 Recent work completed in the UK provides a useful framework for differentiating and connecting these industries based on the ways in which commercial value is created and where this value is located.
} 
is heavily reliant on social capital and in many cases cities can do more to help creative and cultural workers successfully leverage the potential opportunities this offers them.

\subsubsection{Organizational Change $\mathbb{Q}$}

The think tank Demos ${ }^{12}$ recently suggested collaboration should become a basic design tool for government. Local governments across North America, Europe and Australia are in the midst of a transition from the traditional planner, provider, and deliverer model to a more collaborative model.

City Hall can no longer do it alone. The complexity of the issues facing municipal government and civic life requires that the entire pool of problem solving experience and talent in the municipality be tapped. Collaboration, within and between local government departments; between local government and the wider public sector and its agencies; and the wider community and business spheres offers municipal government the potential to pursue its social and economic strategies in a more participatory and consensual way.

This study identifies the need to develop partnerships across municipal departments and in the wider community. It is through collaboration and partnerships that the foundation of dynamic global centre will be built. It is only through the collective efforts of the City, the community and businesses that cultural infrastructure and institutions, complete communities and new forms of wealth creation, will be achieved.

\subsubsection{Fostering Creativity $\stackrel{1}{ }$}

For much of the past 20 years the debate about the public value of the arts and culture has focused on their instrumental benefits and the measurable outputs that flow from them. These have primarily focused on economic

12 The Collaborative State: How working together can transform public services, DEMOS (2007) 
value and contribution to local, regional and national economies. However just as what you can count, counts, increasingly there is a revived assertion of the value dimension of culture or what you can't count, counts. The value dimension of culture addresses the intrinsic rather than the instrumental benefits of culture and creativity. For most people, participation in cultural activities is focused on the pure personal pleasure derived from their solitary or collective involvement as audience or creator, amateur or professional. The value is described as relationships, shared identity, shared memories, shared experience, standards, and beliefs. What we consider valuable to pass on to future generations.

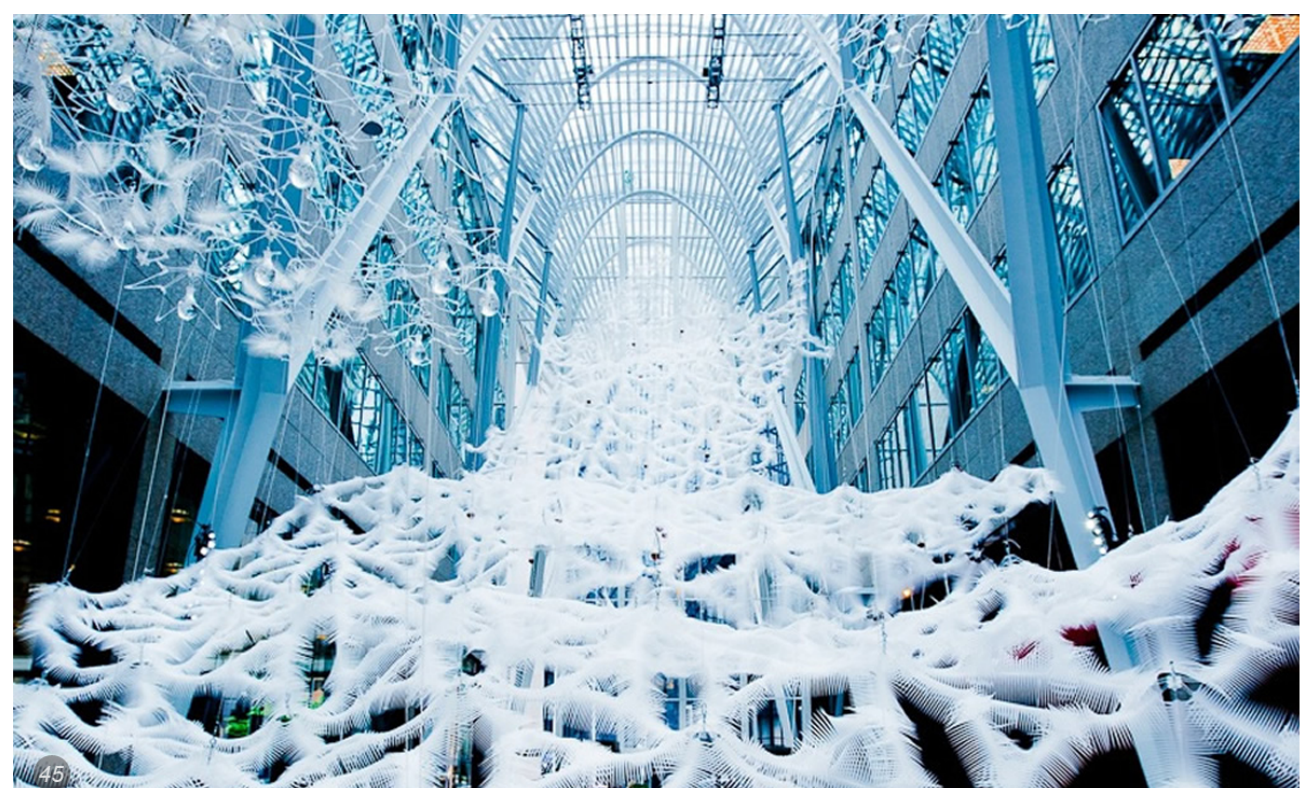

Figure 45 Philip Beesley responsive art installation 2010, Sargasso, transformed Brookfield Place, Toronto

The importance of what we value and wish to leave behind is perhaps most powerfully reflected in the identification and preservation of local culture landscapes, in which the City has been a leader. Local cultures offer potential personal and community benefits of participating in and accessing the arts. So there are number of ways the City can support the growth of a shared identity for Toronto and ensure cultural resources for all its citizens throughout their lives. 


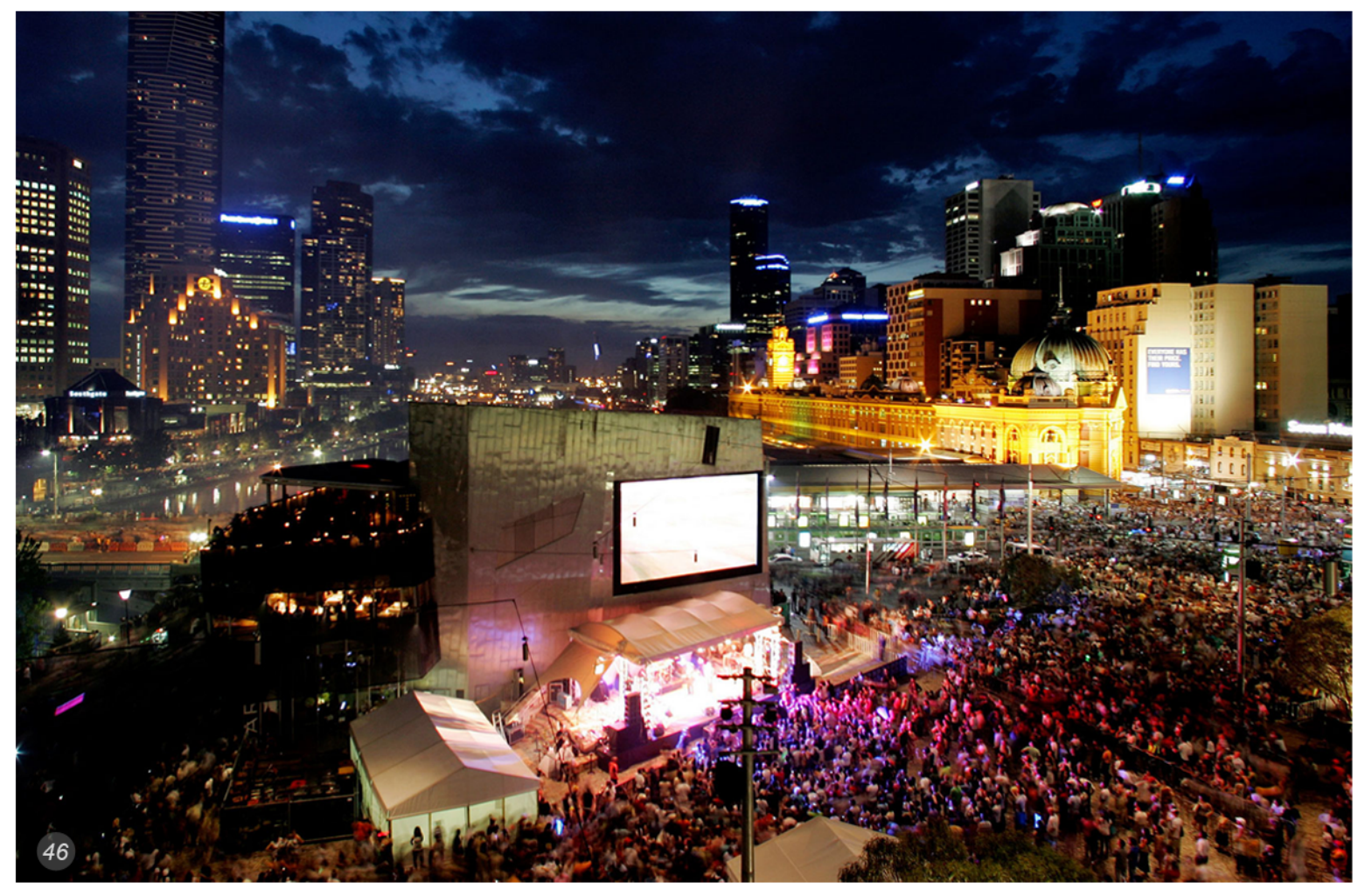

Figure 46 Federation Square, Home to major cultural attractions, and world-class events that has become the Melbourne's meeting place. Melbourne, Australia 


\subsection{Conclusion}

The development of globa:local architecture illustrates that local culture thrives best where there are dense, diverse and accessible cultural facilities, joined with a cultural workforce that mixes different skills and occupations.

The key in this case is to develop a strong, shared vision from the ground up that reflects the dreams and aspirations of the local community. Also, connecting key nodes of local cultures is essential; building networks between existing cultural clusters and its areas of potential may enhance this process.

In some cases, a "hands off" approach may be best for letting a local culture thrive in a global age. In others cases, protection of existing cultural clusters may be called for. In yet others, policy interventions may fuel the spark of an emerging local culture. In all cases, knowing that a local culture is present is vital and people often underestimate the power and capacity of local communities. When a critical mass comes together they can be a powerful force for globa:local architecture. 


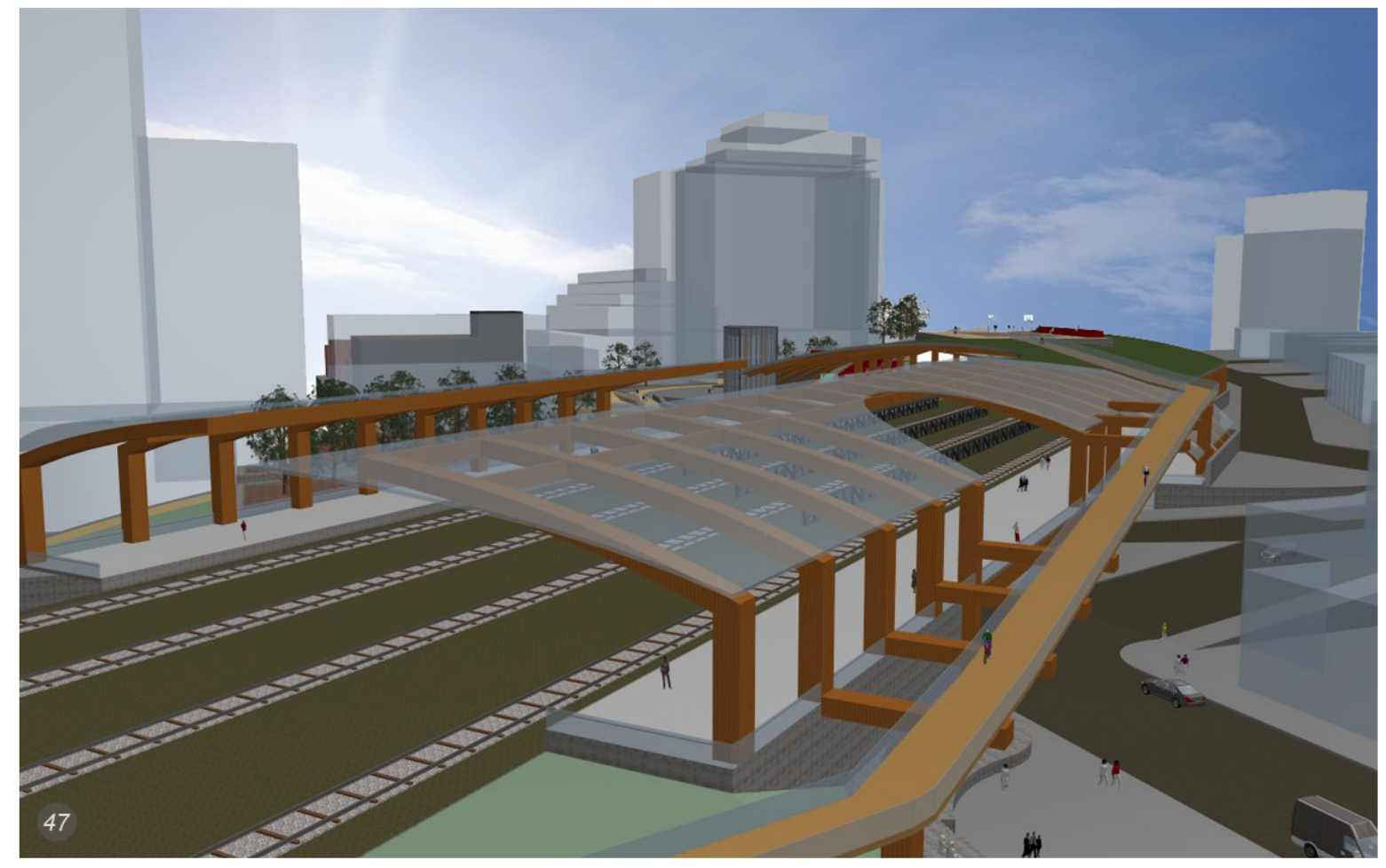

Figure 47 View toward southeast and Queen Street West and Dufferin Avenue Intersection. 


\section{Design Proposal}

This chapter offers my design proposal, which reflects a critical architectural 3D planning exercise driven by the global:local phenomenon (Figure 47) and conceptualized through a design strategy based on the combination of local and global agendas and lessons learned in this research.

\subsection{Redistributing the Local}

After my exploration of globalization and culture in relation to architecture, it became clear that regional local cultures give a profound meaning to the city's context and this richness of experience is rare and special. Therefore, the concept of globa:local place becomes highly anticipated especially in planning policies related to existing communities.

The need for the local social agenda can be clearly defined through the importance of local nodes, where the current social context of some neighborhoods are not well defined, Such neighborhoods need a transformation agent to not only address their physical aspects but also to respond to rapidly changing global needs. This provides a real life analysis for the conclusion of the thesis.

I strongly believe that the future development of local cultural environments need to be conceived based on the principles of a globa:local place and on the integration of different techniques in terms of services and policy making. This will confirm and complete the quality of place making. 
Therefore, promoting a 'hot spot place' for communities would enforce close proximity between neighborhood members and the local node in order to create a functioning public realm based on principles of the globa:local phenomena.

\subsection{Design Methodology}

One of my objectives with this design is to bring the "bones" of this neighborhood to the surface and then allow contemporary elements of arts and events to shine within the space

Based on the evidence I present and discuss in my thesis, the design should foster and support a healthy micro economy, which drives healthy development, light industry, and cultural work. So the design strives to maintain a broad community-based clientele and showcases a diverse array of events. It is a place where local artists exhibit their work and perform and, more importantly, a place where artists and regular neighborhood patrons can simply hang out.

So it is more than just a place. It is in essence an ongoing experiment in cultural entrepreneurship and urban development. It will allow participants to embrace creativity and invite collaboration and innovation.

Based on background research and a demographic statistical analysis of Ward 14 (Parkdale-High Park) it was clear that this area of the city inquires a vibrant public place for strengthening social cohesion.

The analysis showed that over two times the average population of artists and musicians live in this ward and $32 \%$ more than average population use public transit; the area is also very much underserved by recreational facilities compared to other parts of the city. This led me to consider the site for my design proposal. 
As a result I have used the land around the CN Rail corridor in conjunction with the Queen Street West and Dufferin Street intersection to design a "hotspot place". The following diagram clearly identifies and shows the characteristics of each area of land (Figure 48).

In brief, the idea is to create a guiding model by redeveloping a non-place. This project is constantly pushing and pulling between promoting Toronto's creative community and protecting and preserving the creative community's place in a neighborhood that is becoming increasingly gentrified.

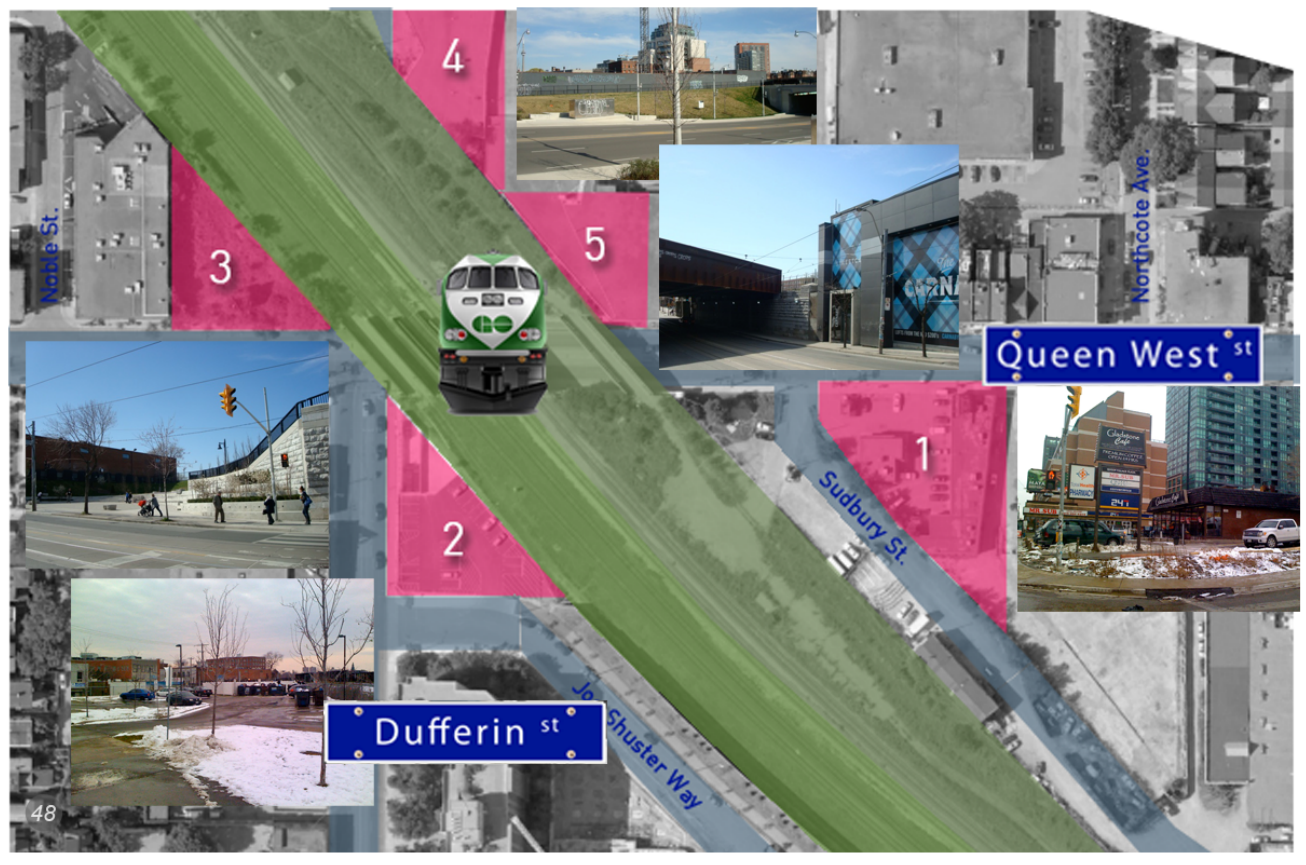

Figure 48 Use the lands around CN Rail corridor to develop a globa:local place 


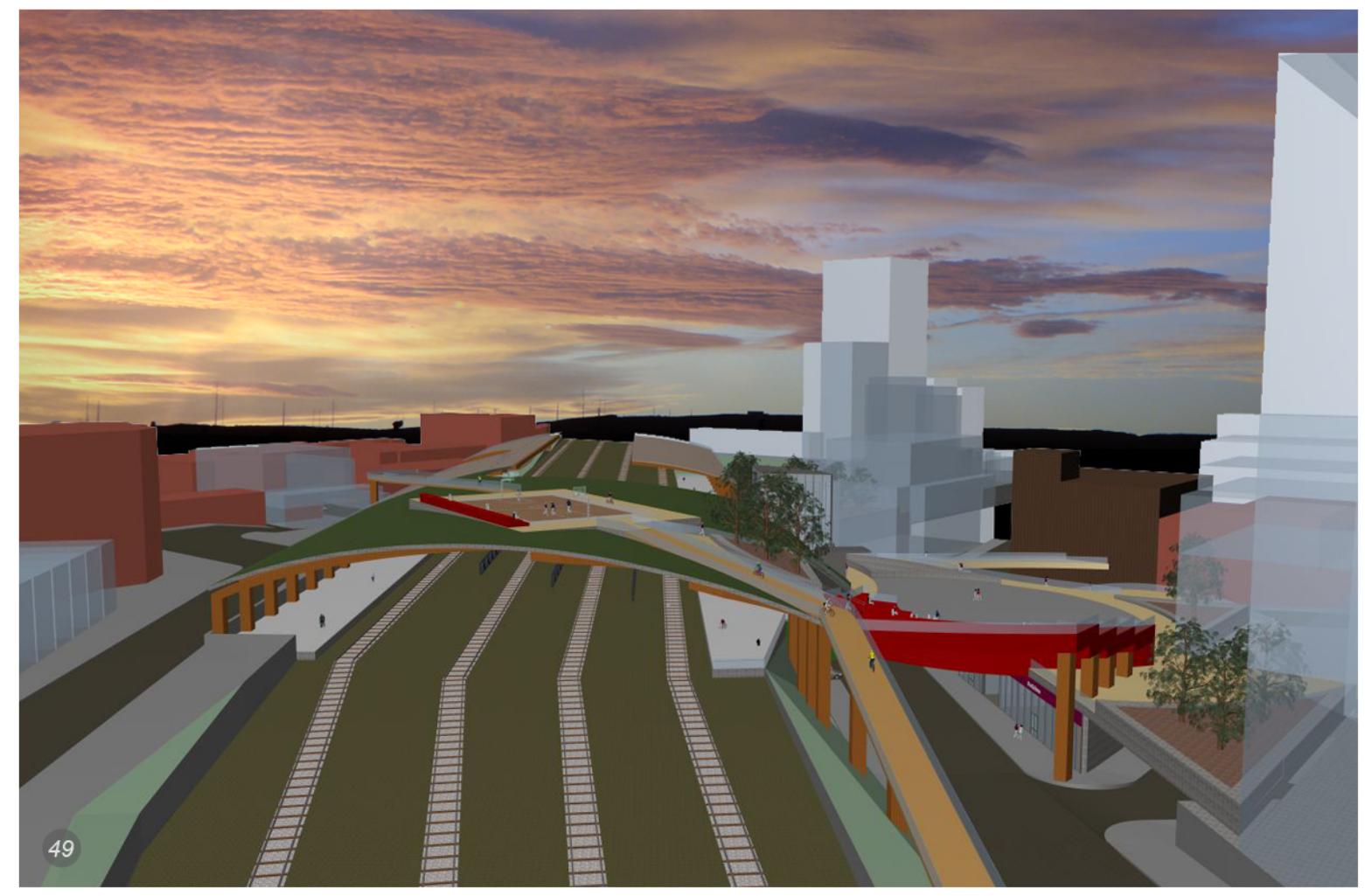

Figure 49 View toward Northwest from CN Rail corridor 


\subsection{The Vision}

The vision of this thesis is not simply about designing a building or repurposing a structure. It is to build a vibrant, resilient and inclusive place that engages art, culture and creativity as catalysts for community transformation, prosperity and livability.

It is also about building a community within and beyond the walls of the project. It is envisioned as a place that could help heal the differences in the community and become a meeting place for area residents.

Therefore I produced a series of designs to explore the potential of the idea in relation to local residents and the context. Through these explorations, I realized that the buildings we design are platforms for the community to get together and thereby foster a stronger community.

Finally, the project vision is based on the idea that a multiplicity of uses always makes for a more animated and successful initiative (Figure 49). By mixing a wide array of activities from a variety of backgrounds and disciplines, globa:local architecture is intentionally designed as a platform for collaboration where an organic mix of people and ideas can come together in unexpected ways to build a better community and city. 


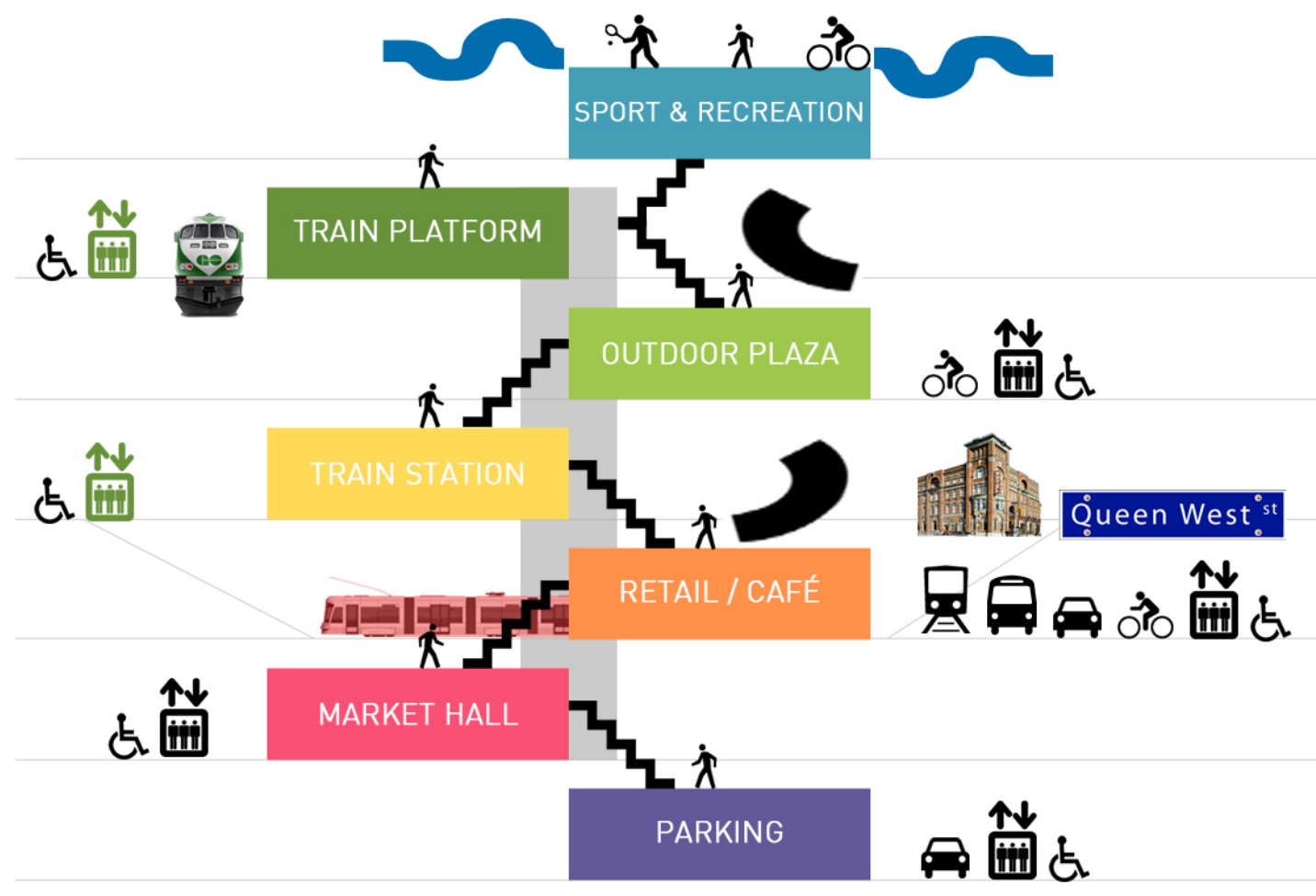

50

Figure 50 Vertical circulation diagram with the proposed site amenities 


\subsection{The Plan}

Globa:local architecture took account of the current and future needs of the community residing in the Parkdale neighborhood. It began with a detailed understanding of the artists' living and working space requirements, which greatly helped the development of a successful design.

In doing this, I far exceeded the needs of the community for open space. For that reason I reduced the size of the building and accommodated the requirements of individual users (Figure 50).

In order to create a cohesive approach to the design, the criteria of the following five groups were combined with the concept of separation between temporary and permanent infrastructure.

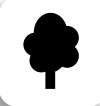

Creating Quality Places: The resources and policies that foster a sustainable quality of life for all individuals.

Strengthening Social Cohesion: Cultural activities and experiences that bring people together, promote the well being of individuals.

Fostering Creativity: The capacity to create the conditions for creativity to
flourish.

Economic Activity: The ability of the place to generate wealth.

(1) Organizational Change: The integration of globalization planning across all facets of government and decision-making 

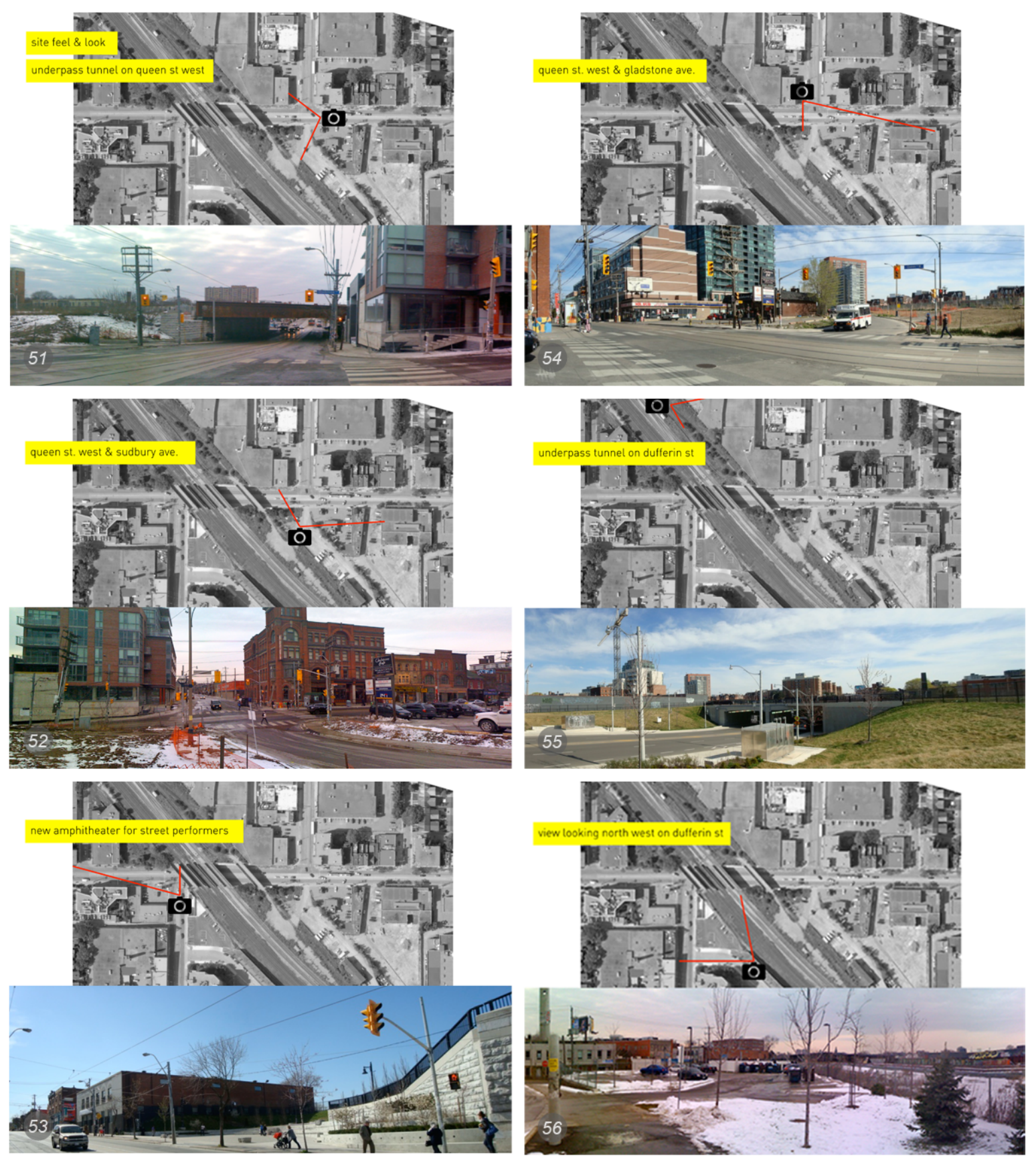

Figure 51

Figure 52

Figure 53

Figure 54

Figure 55

Figure 56
Looking west on Queen Street West towards underpass tunnel

Looking at the intersection of Queen Street west and Gladstone Avenue.

Looking at the Gladstone Hotel that acts as a cultural node in this neighborhood Looking on Dufferin Avenue toward south and seeing the new underpass tunnel

The new outdoor amphitheater right and the intersection of Dufferin Avenue and Queen Street West

View looking north at the CN Rail tracks and the small parking area next to that 


\subsection{Character of The place}

This neighborhood is one of the most diverse areas of the city, with many new immigrants finding their first homes here because of the high concentration of low-rent apartment complexes and proximity to the downtown core. The presence of a large immigrant community has done much to create the vibrancy and personality that Parkdale is known for. Approximately 77 percent of Parkdale residents rent their housing, compared to a city-wide average of 32 percent.

Today, Parkdale is transforming into a hip neighborhood as the area sees an influx of artists working in relatively inexpensive spaces, close to the exhibit spaces on Queen Street within Parkdale and along Queen Street to the east. $^{13}$

"Hipster" cafés, lounges, restaurants, condominiums, shops, and art galleries are cropping up, and former "dive" hotels such as the Drake and the Gladstone have recently become local nodes in a trendy manner (Figure 51 to 56). Local taverns have begun receiving new patronage from artists and urbanites seeking refuge from the fashion boutiques farther east on Queen Street West.

\footnotetext{
${ }^{13}$ Slater, Tom. "Toronto's South Parkdale Neighbourhood A Brief History of Development, Disinvestment, and Gentrification". University of Toronto.
} 

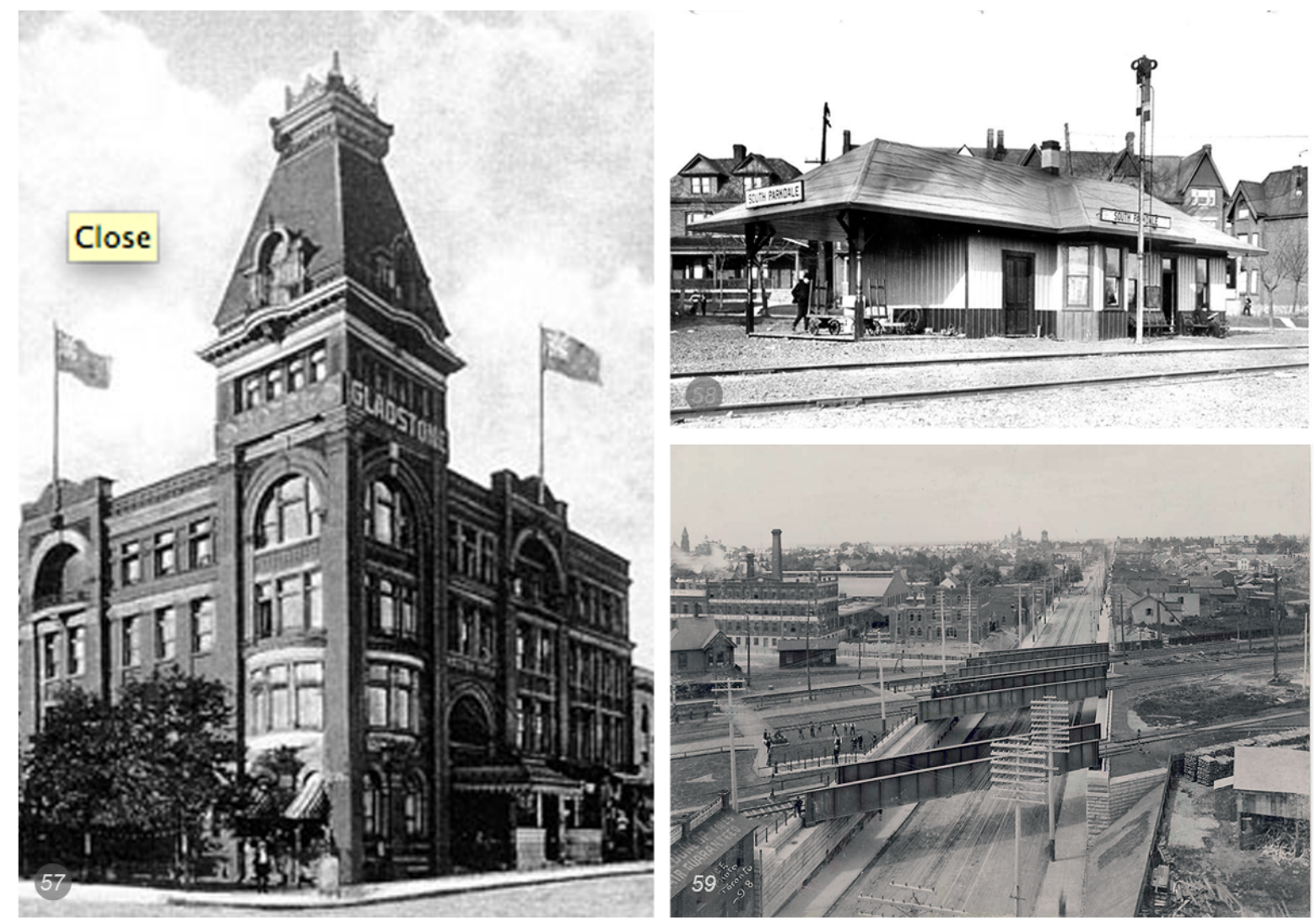

Figure 57 Gladstone Hotel designed by George Miller, 1889. The Hotel was designed in the Richardsonian Romanesque style a popular Victorian style for public buildings such as train depots, churches, and libraries.

Figure 58 South Parkdale Station at queen street west and Dufferin Street, 1910

Figure 59 Aerial view of Queen Street subway at Dufferin Street looking west, 1898 


\subsection{History of The Site}

The Village of Parkdale was founded in 1879. The area's development started with the rail line built along Queen and Dufferin streets (Figure 59), which was operated by the Canadian Pacific Railway Company.

Just east of Dufferin on Queen Street West, is what was once considered the western edge of Toronto and home to the Gladstone Hotel, the oldest continuously operating hotel in Toronto. Architect George Miller built the Gladstone in 1889 (Figure 57). The Gladstone Hotel provided accommodation for travelers from the Parkdale railroad station (Figure 58) as well as visitors and exhibitors at the Canadian National Exhibition (CNE). The hotel has been carefully restored to reflect the building's architectural history.

The Gladstone Hotel has a long history of providing respite for artists and performers. In its early days, it was the "last stop" on the edge of Toronto's city limits before heading west (usually by train). Many artists stayed here after performances at Massey Hall before heading out of town. It was also a favorite spot for vaudeville performers during the CNE. 


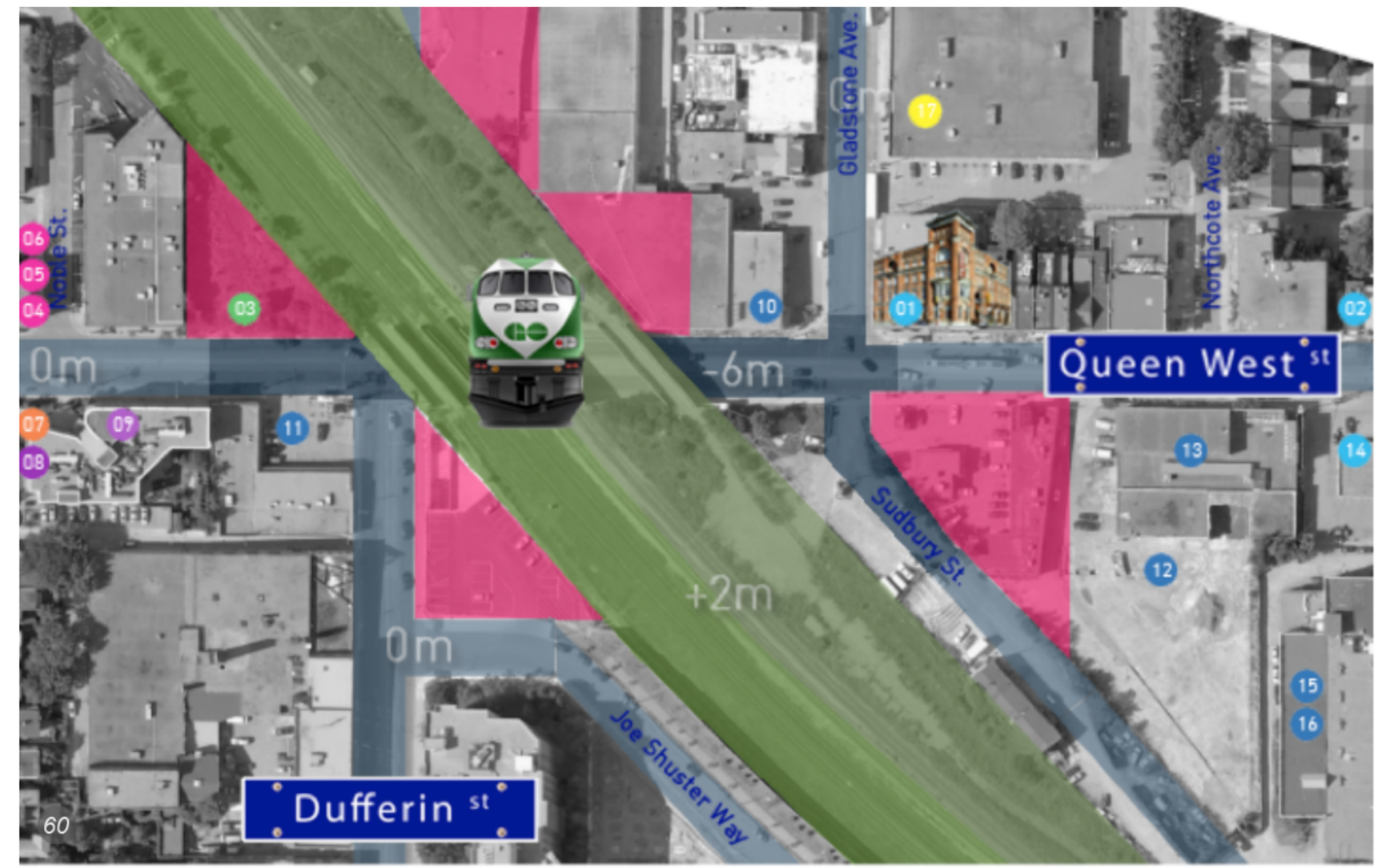

Figure $60 \quad$ Neighborhood Landmarks

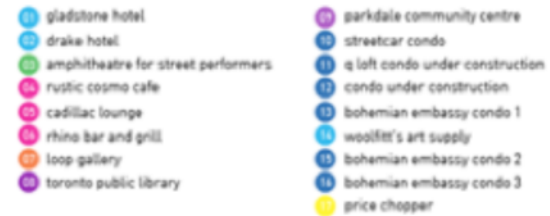




\subsection{Location}

The location I have chosen for my design proposal is in the Parkdale neighborhood, at Dufferin on Queen Street West (Figure 60), which was once considered the western edge of Toronto. The site is actually a series of triangulated wastelands that has been reclaimed for the local community to accommodate spontaneous activities.

Any local culture has many ingredients packed within its boundaries and it is impossible to unpack them. For this reason I made sure that every one of these triangles is reshaped and redistributed such that the task of gathering them again can be made strong.

\subsection{Existing Public Transit}

As of 1890, the streetcar connected this area of the town to downtown and since then there have been several additional routes serving the Parkdale community.

Along Queen Street, streetcars provide a 10-minute ride to the Yonge Spadina subway. Along Dufferin Street, a bus service provides a connection to the Bloor-Danforth subway to the north. 

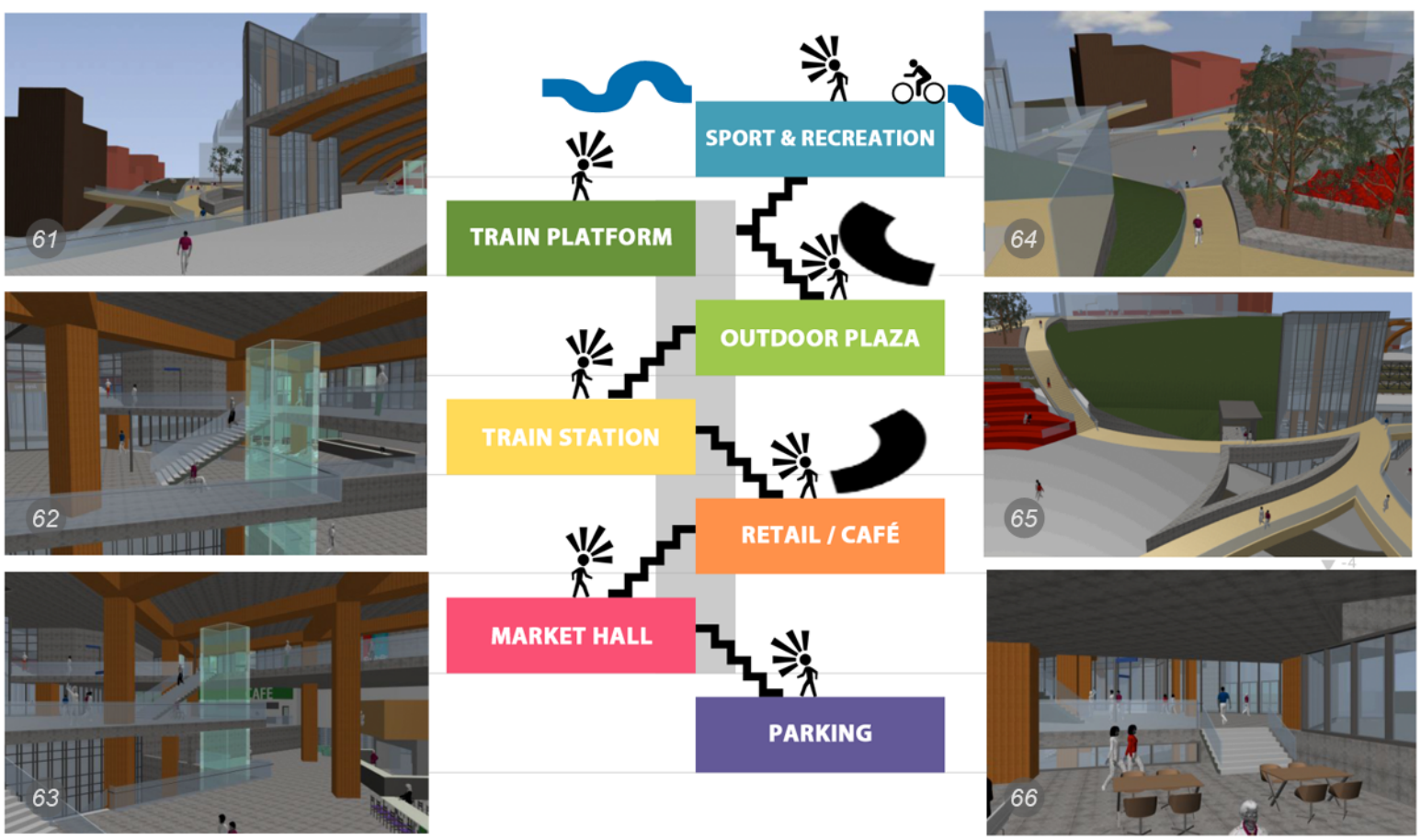

Views from each level showing the way the design proposal is linking activities

Figure 61

Figure 62

Figure 63

Figure 64

Figure 65

Figure 66
View of train station platform towards Queen Street West.

View from market hall towards retail, station, and the parking.

View from parking level toward the market hall.

View from transit level and its connection to outdoor plaza.

View of stairs toward recreational facility.

Internal view from retail towards the market hall and the transit. 


\subsection{Project Components}

In its new role, the triangles across from the Gladstone Hotel and around the CN Rail track will be an interesting addition to Toronto's public realm. This spot will be a highly attractive place for local artists to shine and will become the centerpiece of the Parkdale community.

The size and the character of the expansive public space will allow it to function visually as a major urban park, and all the open spaces formed by promenades along both edges of the CN Rail track will accommodate passive and active recreation. This new addition will include a multiuse recreational field, which will be used by children as well residences of the new development; it will also allow for events and gathering along Queen Street West. Also this proposal includes passive green space connections for essential bike trail connections.

The largest area of open space occurs across from the Gladstone Hotel. This open space is envisioned as a gathering spot and is flexible enough to host festivals, stage events, picnics, and sporting activities. The area will be extremely active across a range of uses and modes of transportation, including commuters and residents traveling by train, streetcar, automobile, and on foot.

The proposed design will provide a desirable place for Torontonians to meet up and walk in any number of directions to a variety of destinations, including an open-air plaza, an event plaza, pedestrian bridges, a transit hub, and etc. (Figure 61 to 66). 


\subsubsection{Open Air Plaza}

The open-air plaza will be furnished with wooden decks and natural grass lawns. The plan was to connect all the triangles in order create a train station and use the roof of the station as platform to enhance the spectacular views of

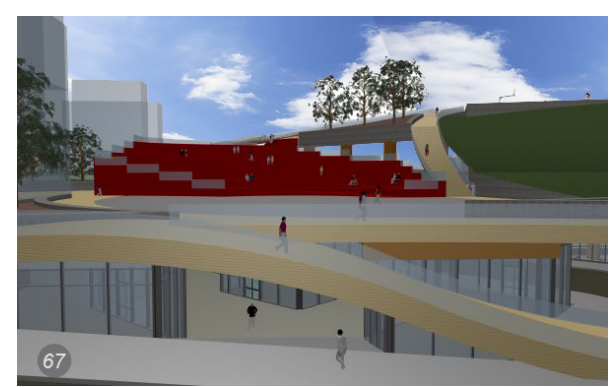
downtown Toronto. However, after the substantial completion presentation I realized that I needed to scale down the height in order for the design to work within the context (Figure 67).

\subsubsection{Event Plaza}

The space across from the Gladstone Hotel can be used as a stage for events like mini-concerts and dance performances, with the surrounding steps functioning as audience seats (Figure68).

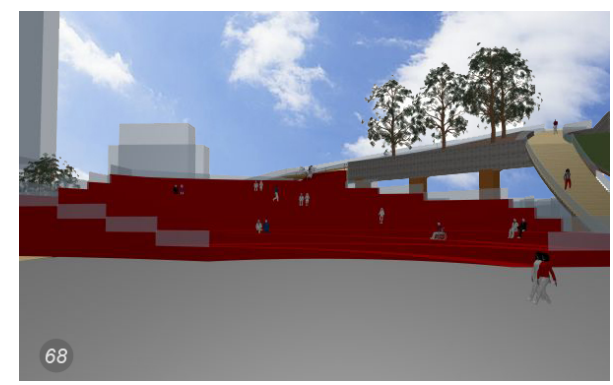

\subsubsection{Transit Hub}

History tells us that this area was once a keystone location between downtown Toronto and Parkdale Village. Due to the recent development boom in this area, the proposed design calls for a transit hub serving the Go Train, Sky

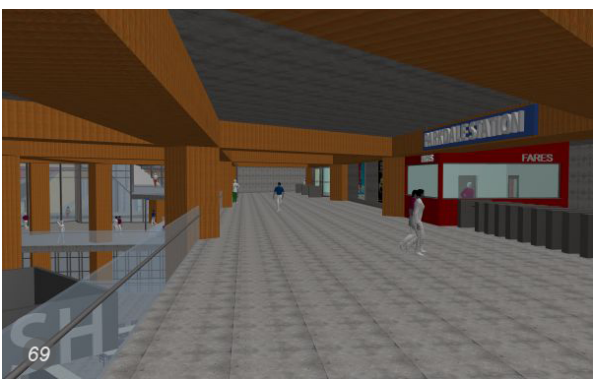
Train, and TTC streetcar, as well as providing cycling and pedestrian routes. This design offers exceptional opportunities for integrating and extending 
these networks to overcome existing barriers so as to reconnect existing local cultures on all sides of the city. It also provides a remarkable potential for creating a vibrant transit-oriented community in the heart of the city, with a strong emphasis on walking and cycling and limited reliance on automobiles (Figure69).

\subsubsection{Retail Outlets}

The proposed design calls for retail outlets to be located under the CNR track, primarily along Queen Street West. Retail activity will also be clustered at the proposed transit station, in particular at the corner of Dufferin and

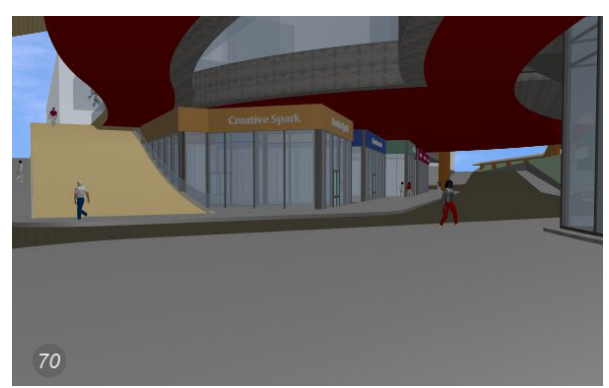
Queen Street West. Retail activity is a key element in creating active and vibrant spaces along key public nodes and at the transit hub. The intent is to not only provide retail outlets for all residents within easy walking distance of their housing, but to also attract visitors from a wider area. A particular highlight is the vision for the south side of the Gladstone Hotel to be a signature location for outdoor related restaurant and entertainment uses due to its unique position along Queen Street West (Figure 70).

\subsubsection{Bicycle Path}

Wooden bicycle path are provided on the rooftop of transit platforms to help visitors explore the area on summer days and to get a clear view of a vibrant part of the city. I believe that this area is currently in great need of improvement at street level. The bridges are another step in transforming this area, creating opportunities for leisurely activity and providing new slow-traffic connections (Figure 71). 


\subsection{Project Drawings}

The following drawings are my final thesis defense presentation drawings that were presented on April $27^{\text {th }}, 2012$. 


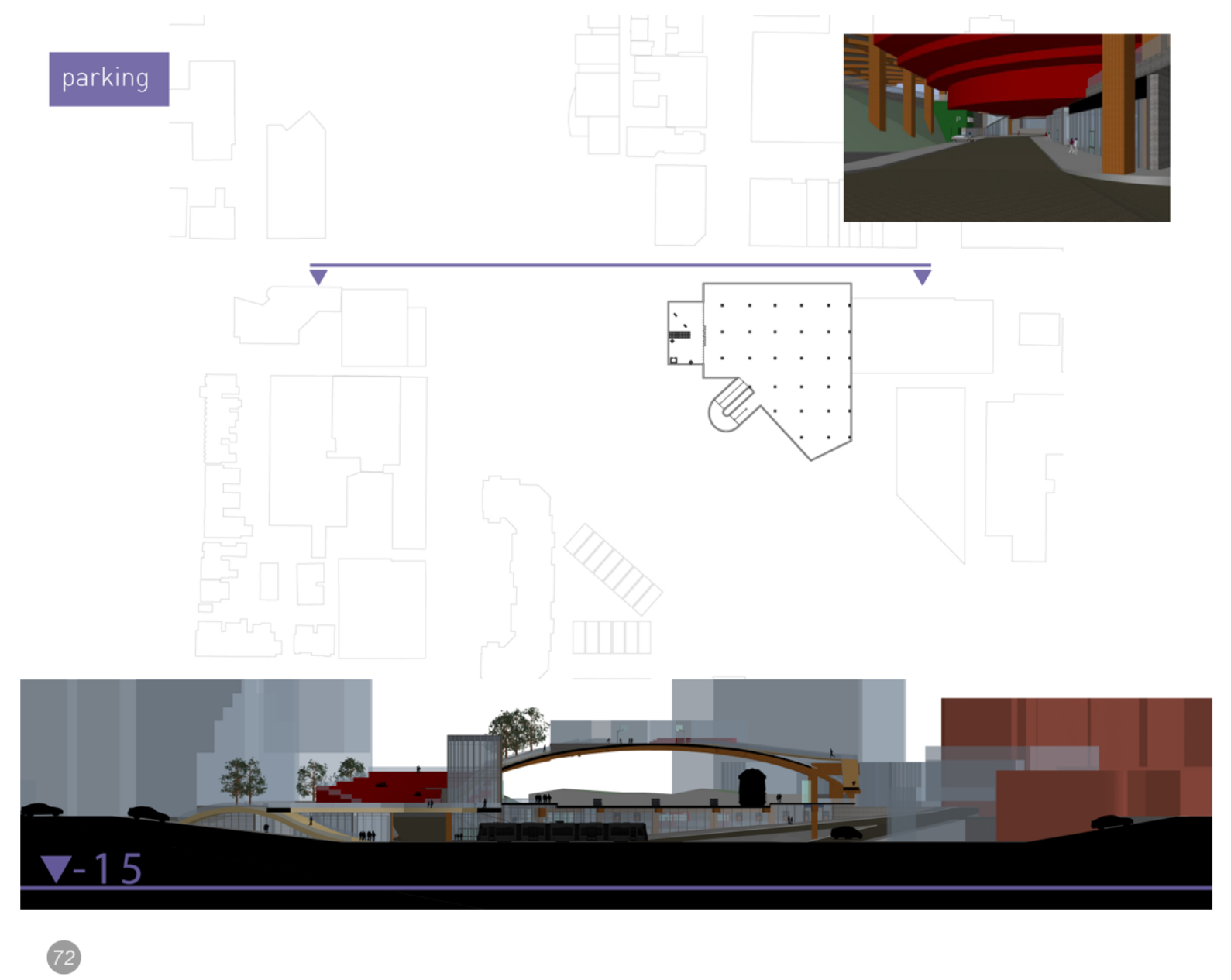

Figure 72 Parking level plan at -15 meter below grade

Video 1: shows the parking entrance and its relation to the intersection of Queen Street West and Gladstone Avenue intersection. 


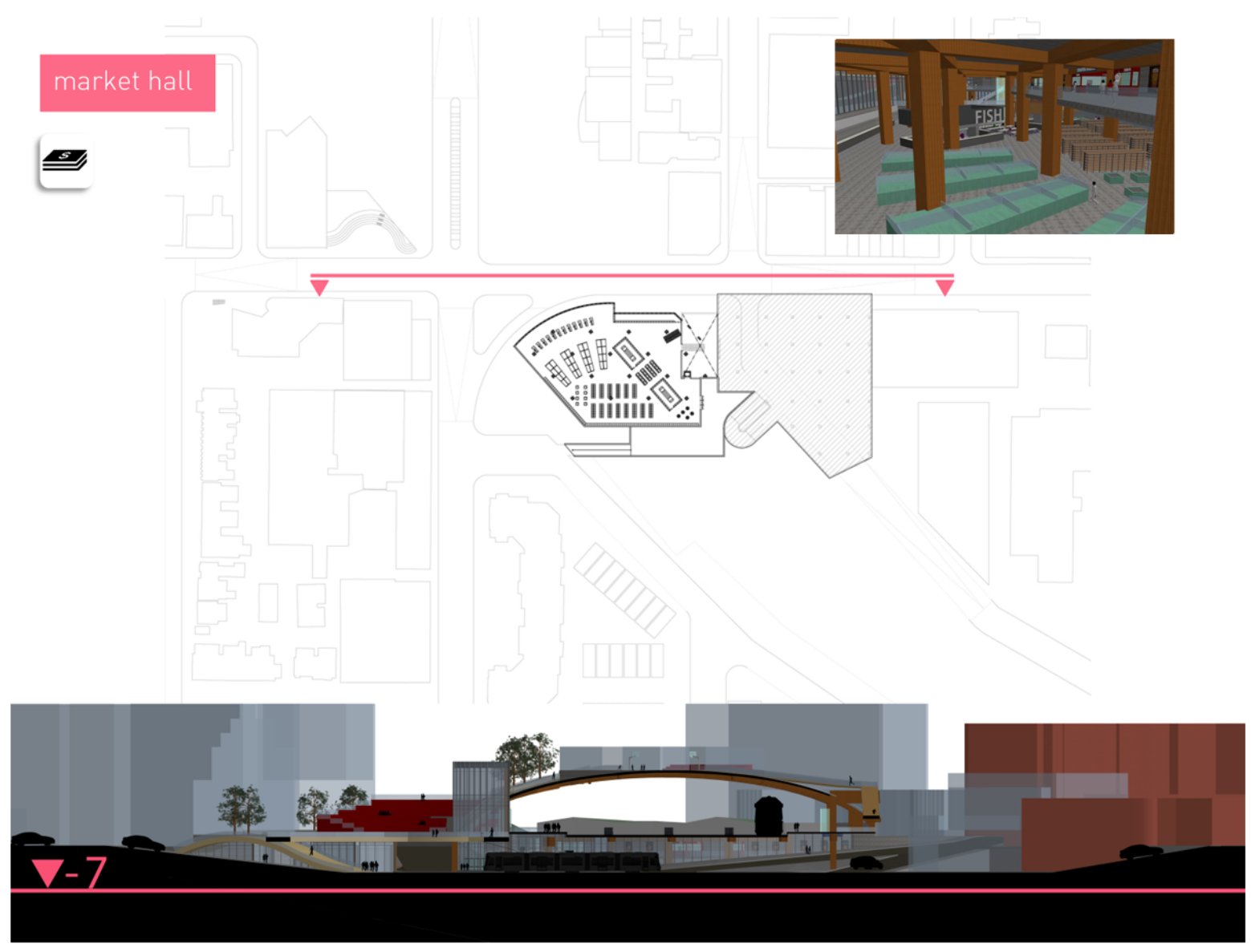

73

Figure 73 Market hall plan at -7 meter below grade

Video 2: Shows the internal plan of the market hall and the structure that resemble the presence of train tracks above 


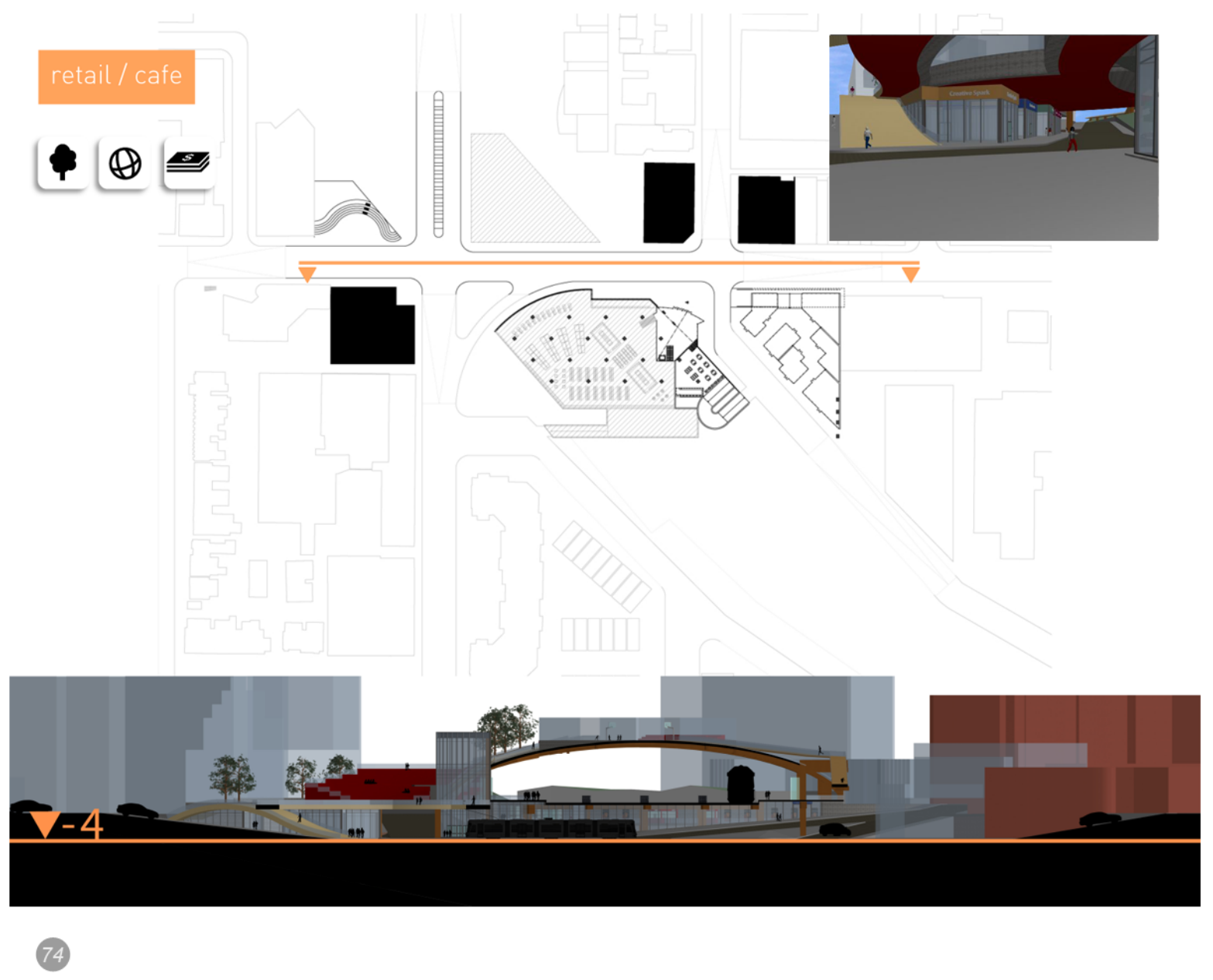

Figure 74 Retail level Plan at -4 meter below grade

Video 3: Shows both outdoor retail outlets and the indoor café 


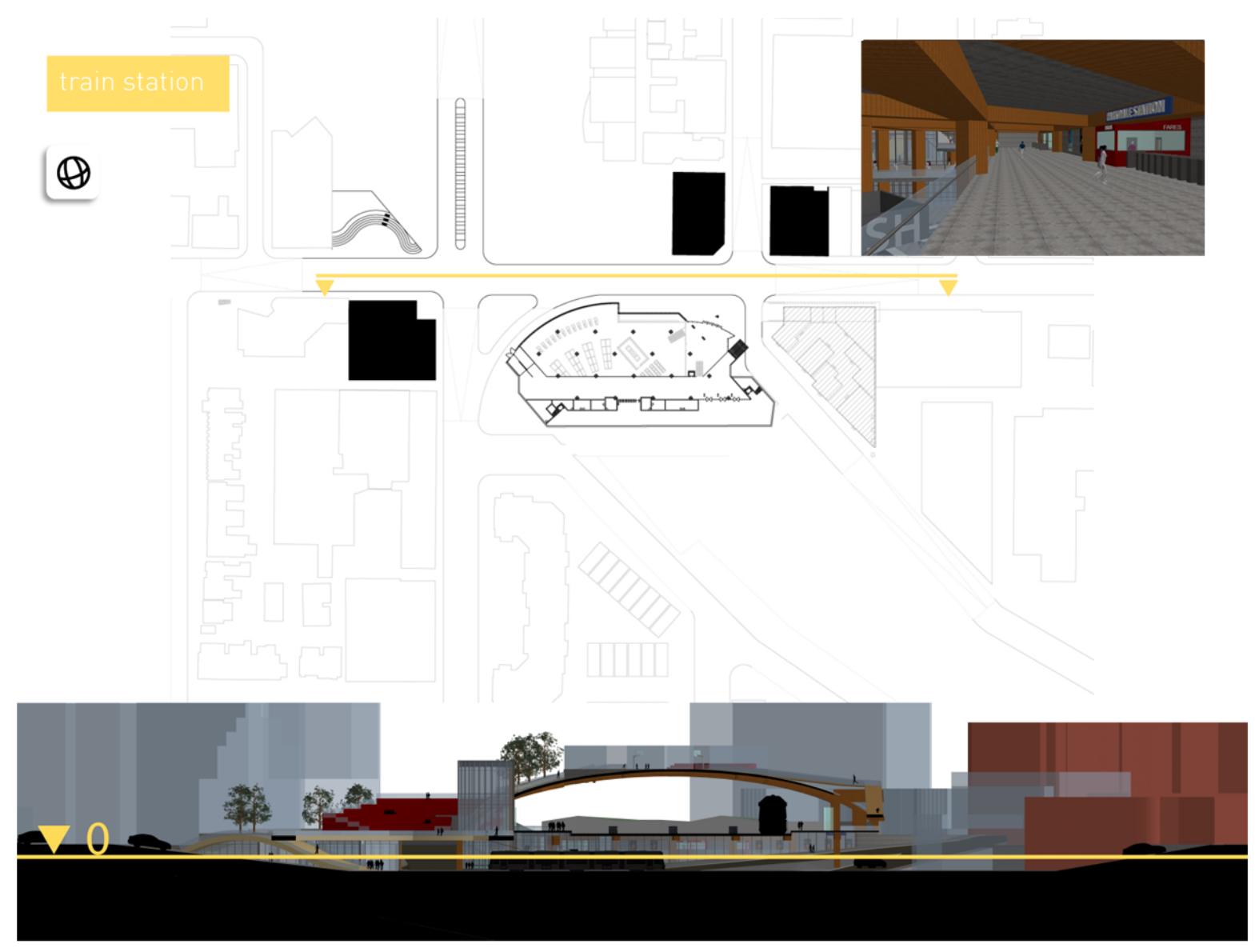

75

Figure 75 Train station plan at -1 below grade

Video 4: Shows the train station entrance that seats above the market hall and below the outdoor plaza 


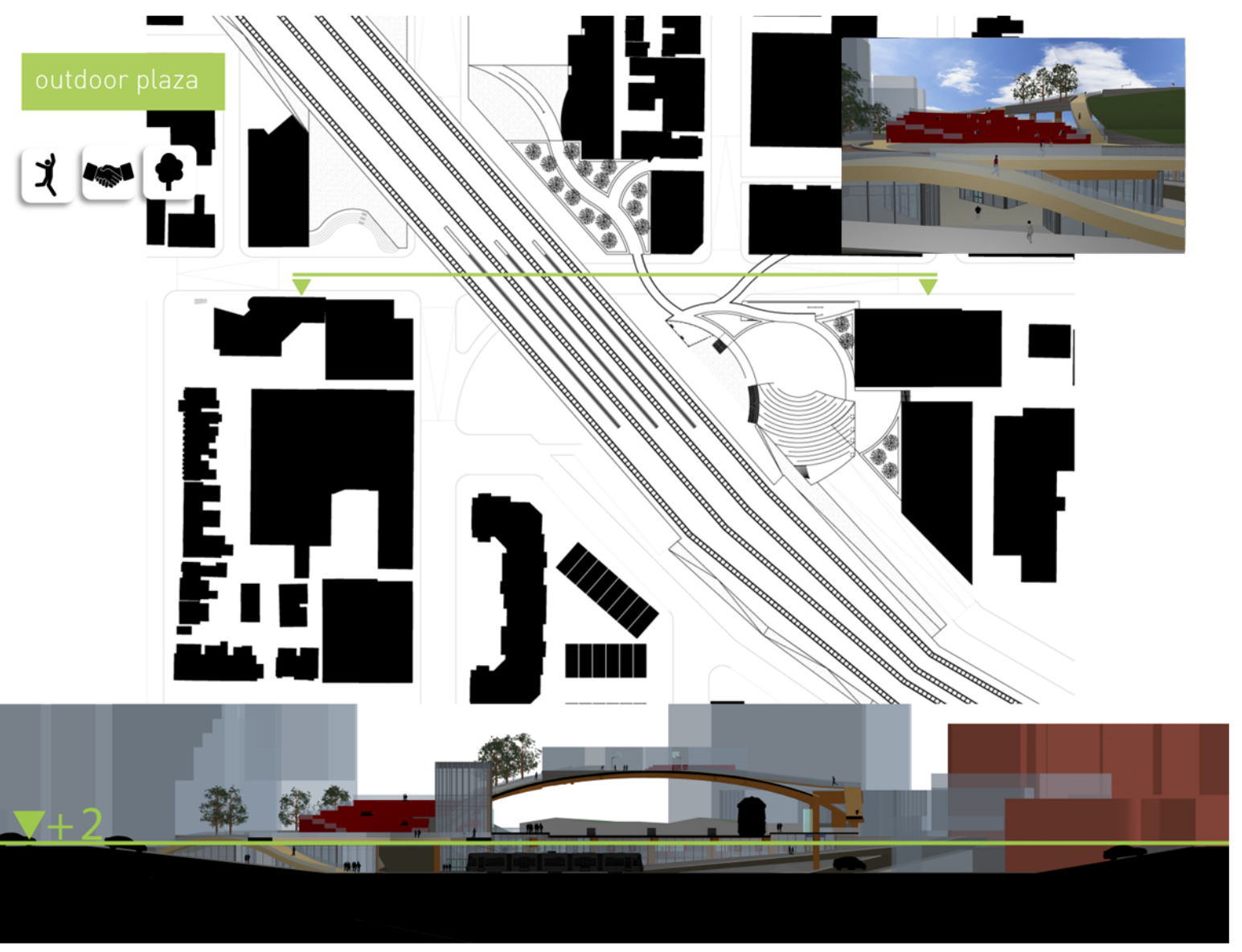

(76)

Figure 76 Outdoor plaza plan at +2 meter above grade

Video 5: Shows the relationship of outdoor plaza to Queen Street West and the Gladstone hotel 


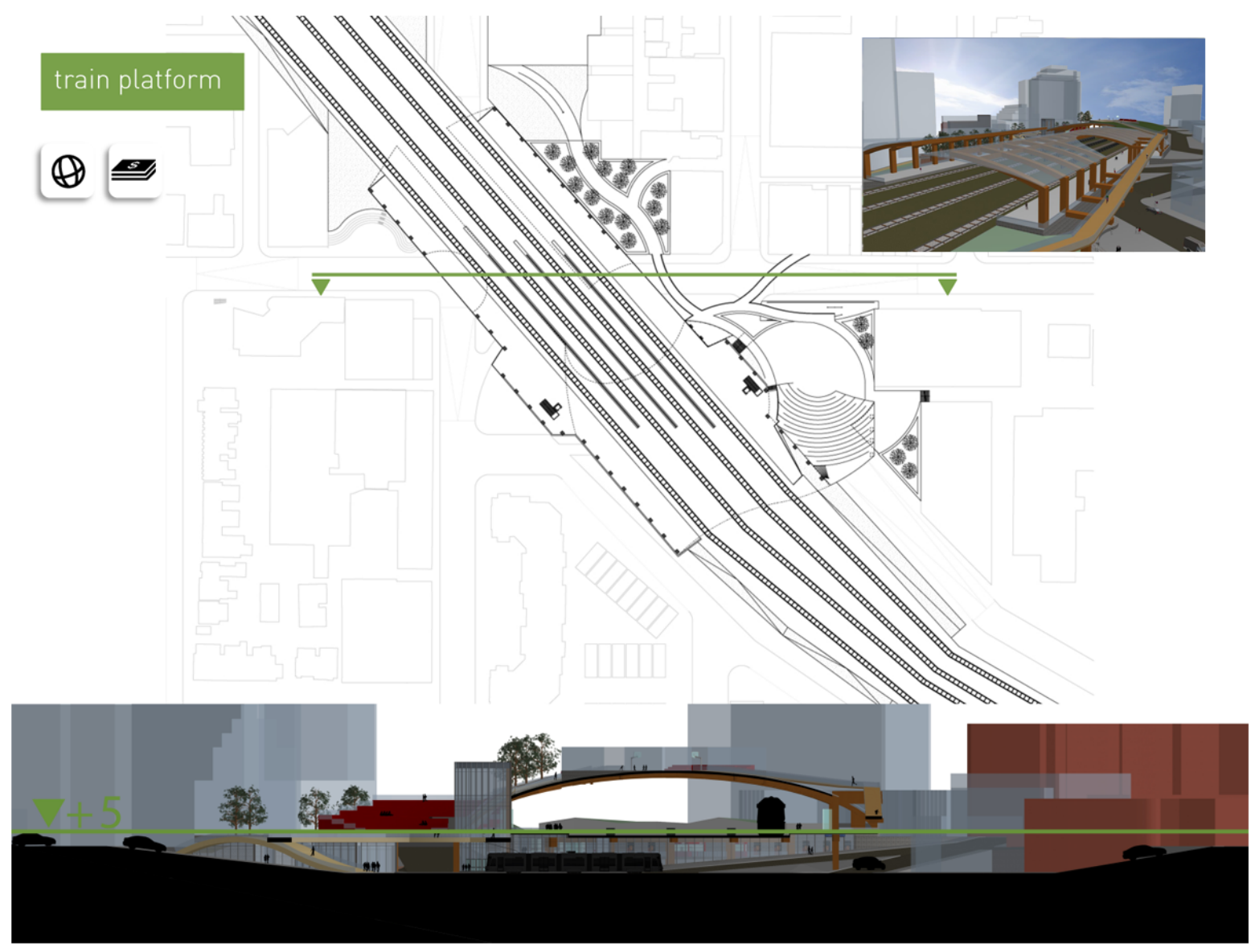

(77)

Figure 77 Train station platform plan at +5 meter above grade

Video 6: Shows both northbound and southbound platforms 


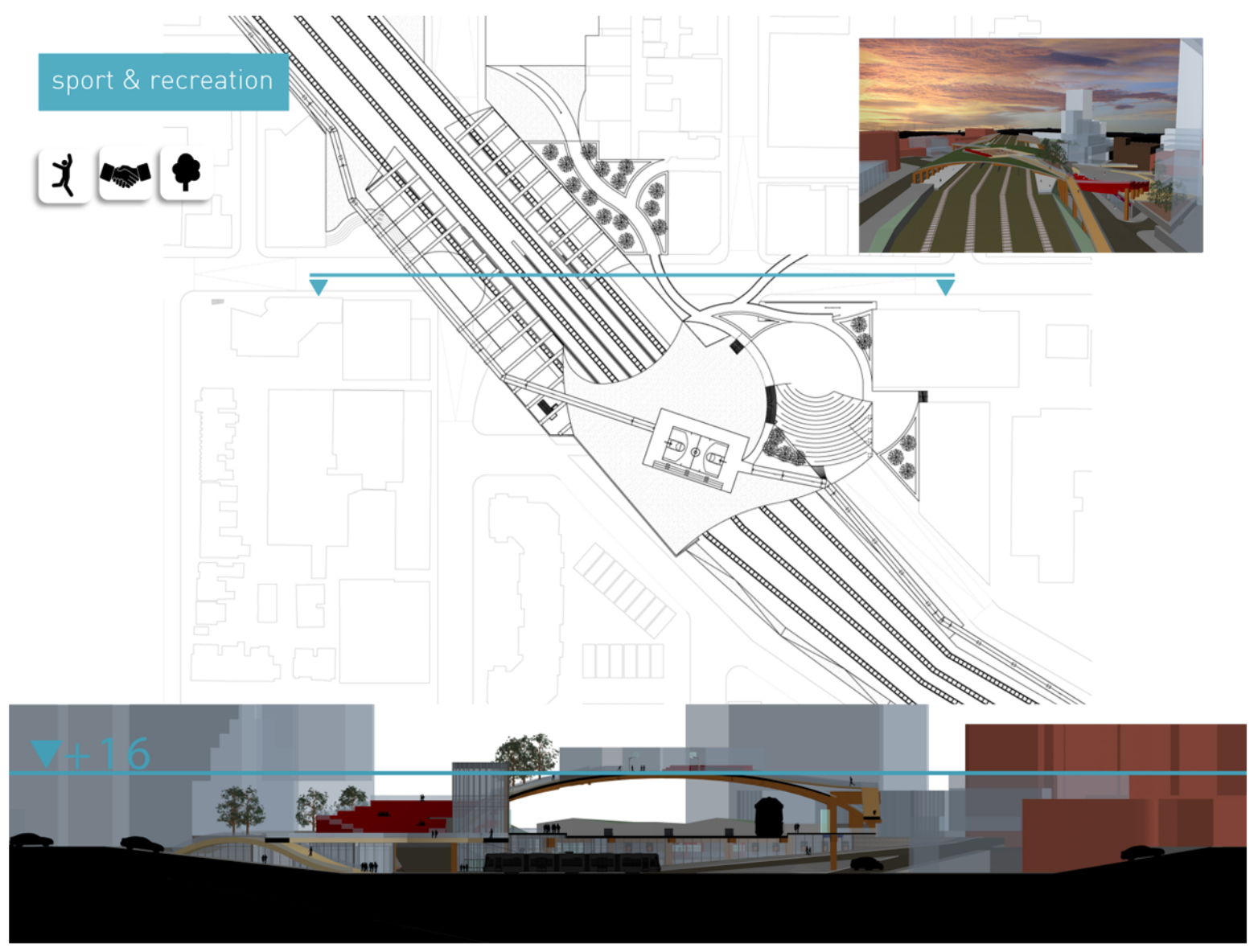

78

Figure 78 Sport and recreation level at +16 meter above grade

Video 7: Shows the reclaimed bike path that rise up to the multipurpose sport field and shows 360 view of the area and finally come down to the outdoor amphitheater at the intersection of Dufferin Avenue and Queen Street West. 


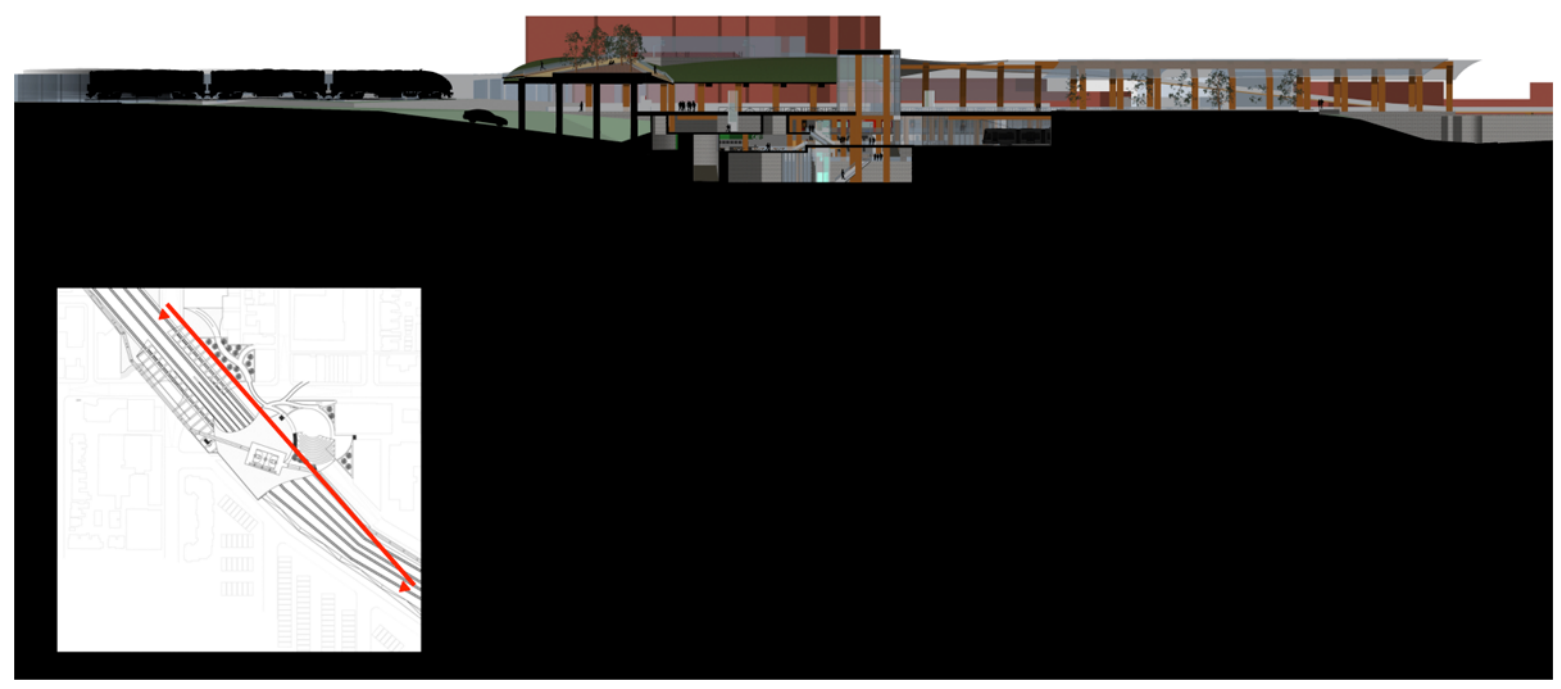

79

\section{Figure 79 North-South Cross Section through Sudbery Street}

Shows the structure, atrium, and the relationship between café, market hall, train station entrance and ultimately the train station platform. 


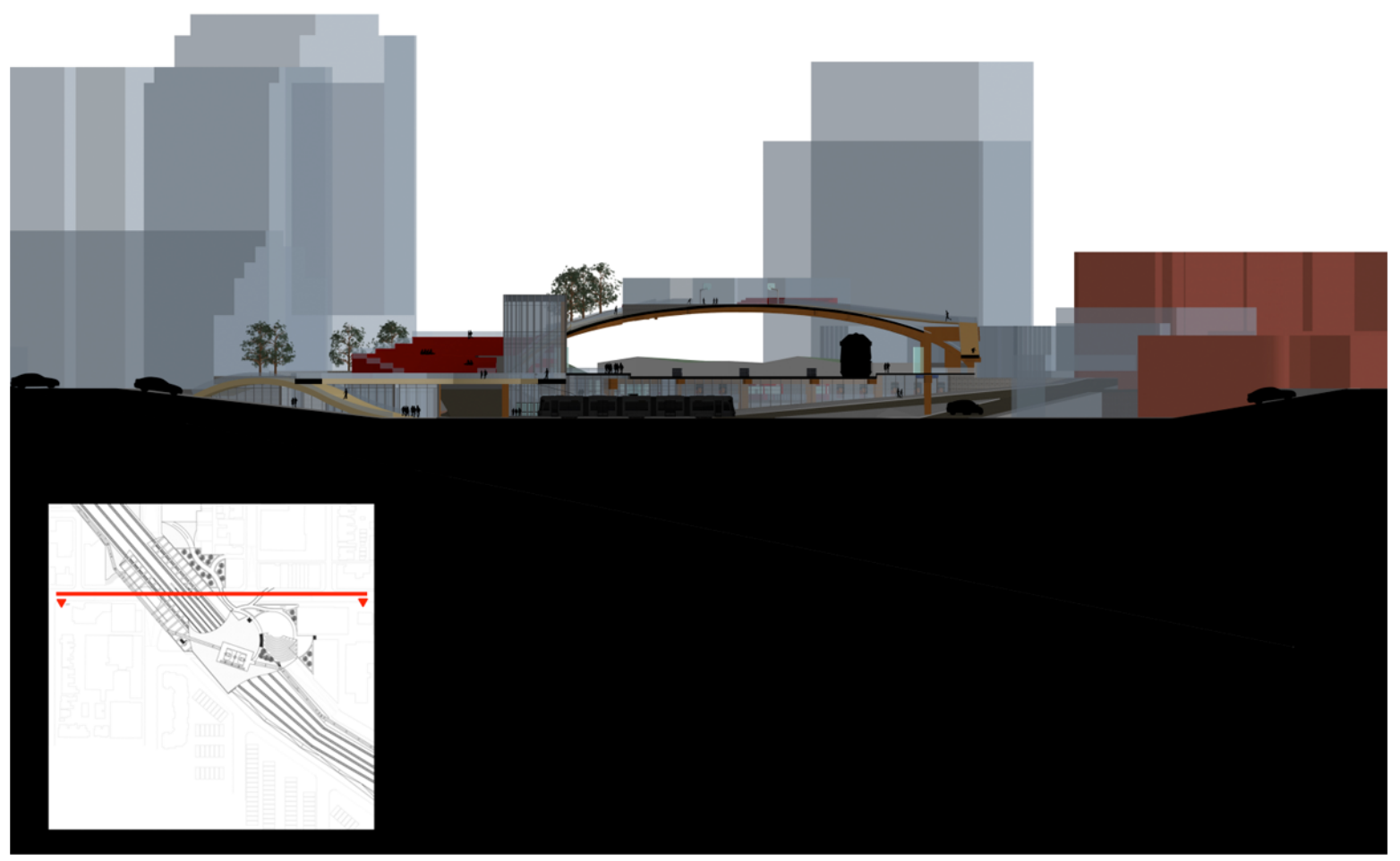

80

Figure 80 East-West Cross Section through Queen Street West

Shows the ramp to the outdoor plaza and the recreation facility on the train station roof 


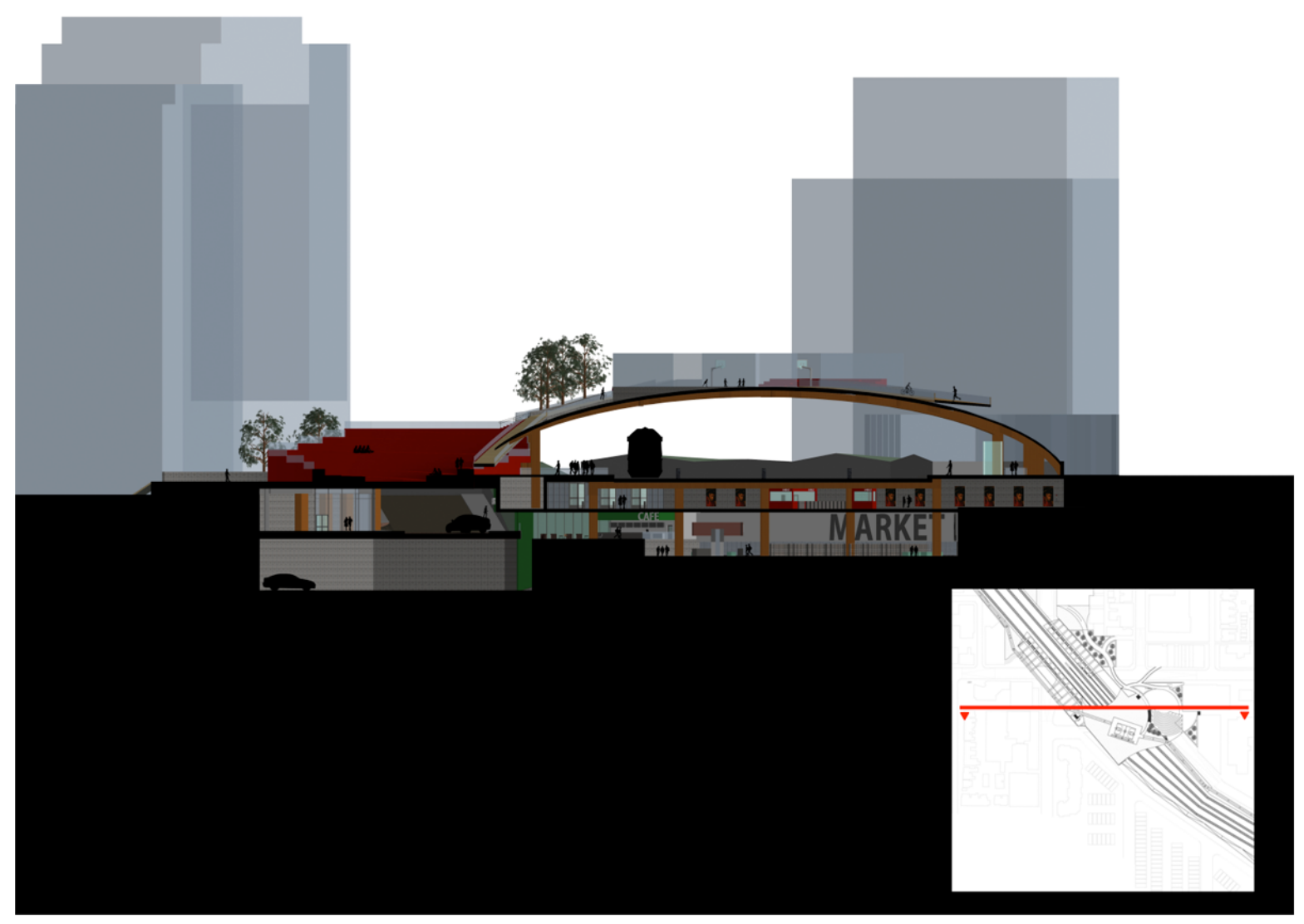

81

Figure 81 East-West Cross Section

Shows the parking, retail, plaza and the train tracks above the market hall 


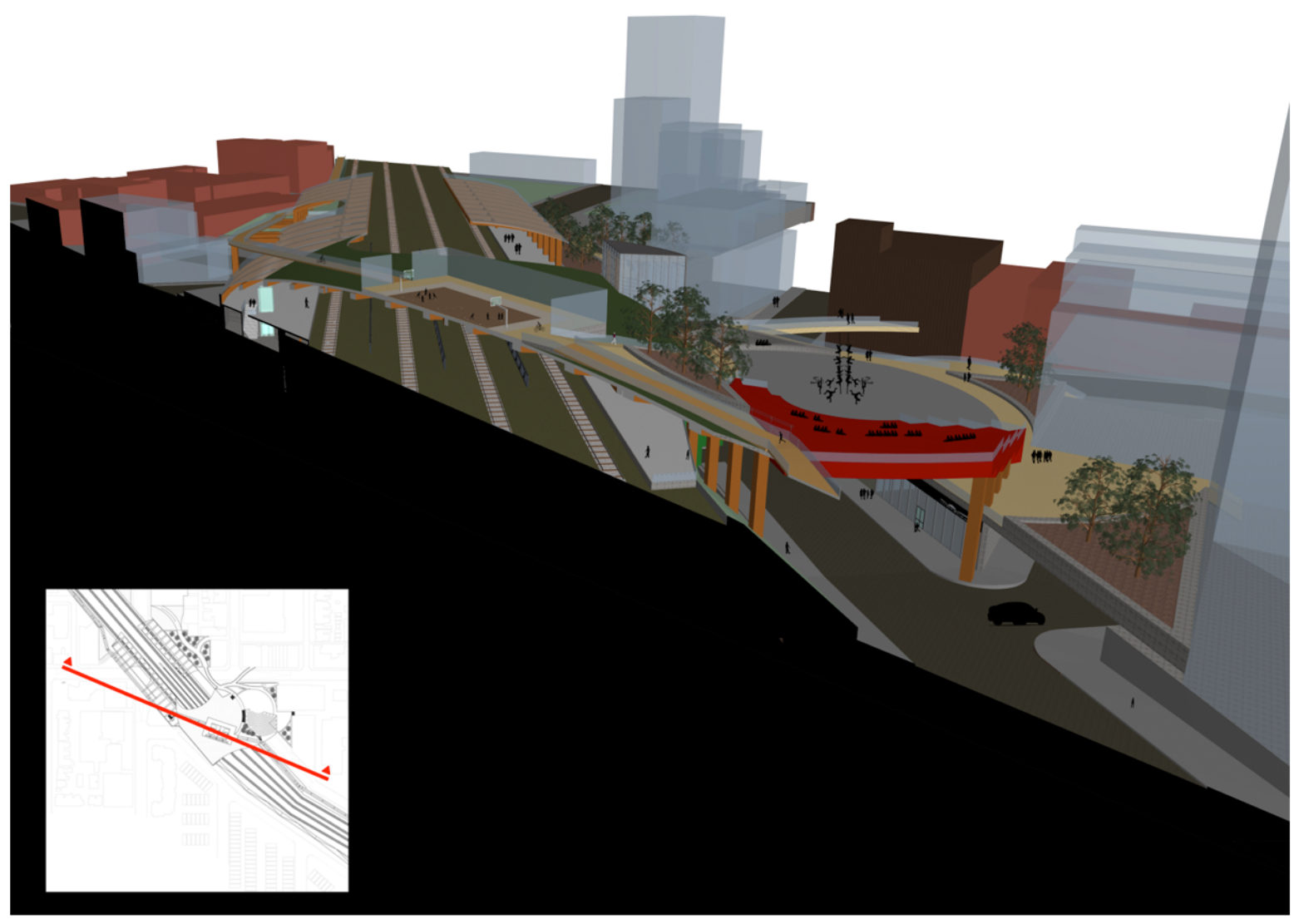

82

Figure 82 3D section looking north

Shows circue du sole performance while other activities takes place simultaneously 


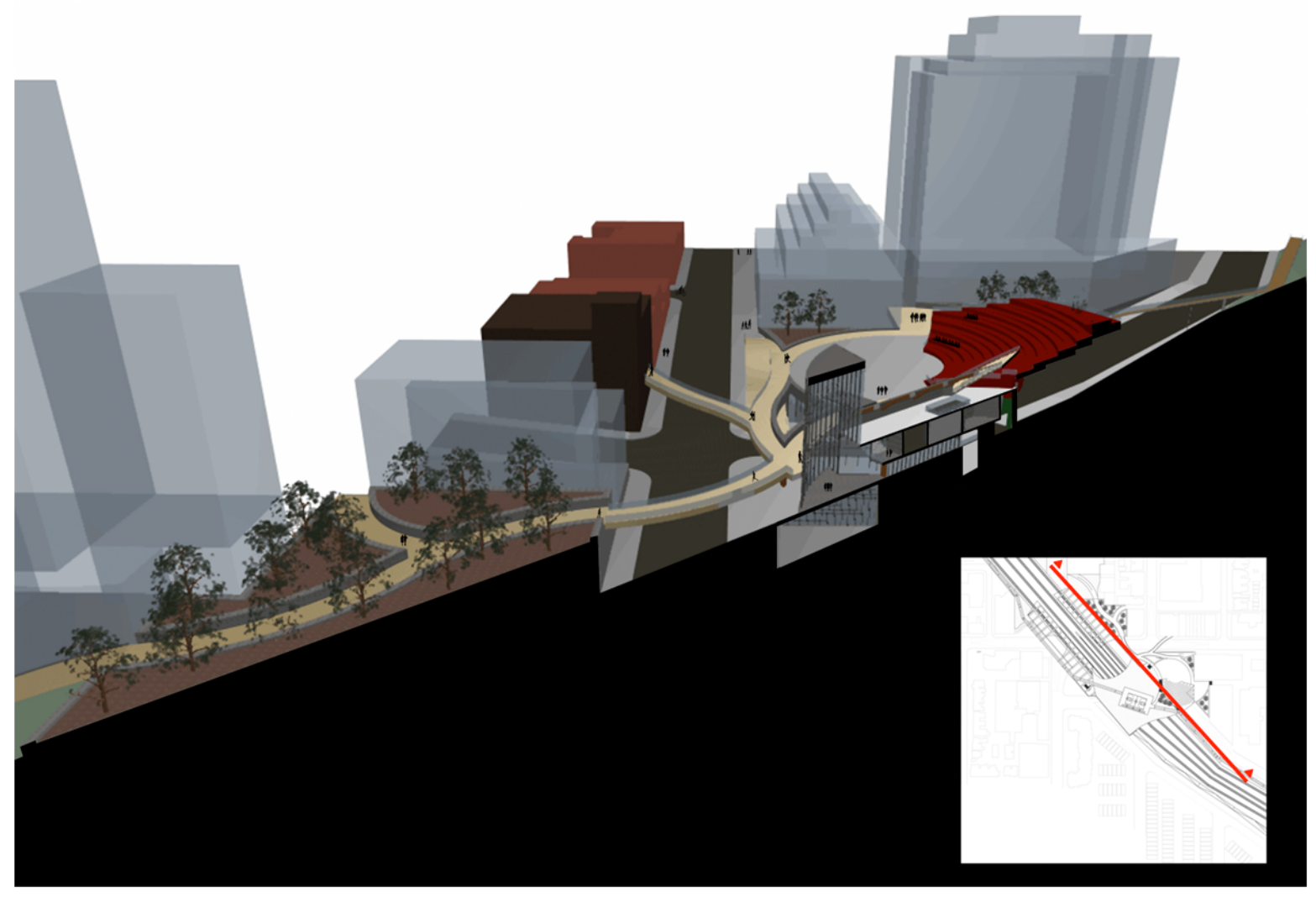

83

Figure 83 3D Section looking east on Queen Street West.

Shows the atrium and the void which tie all the proposed program together 


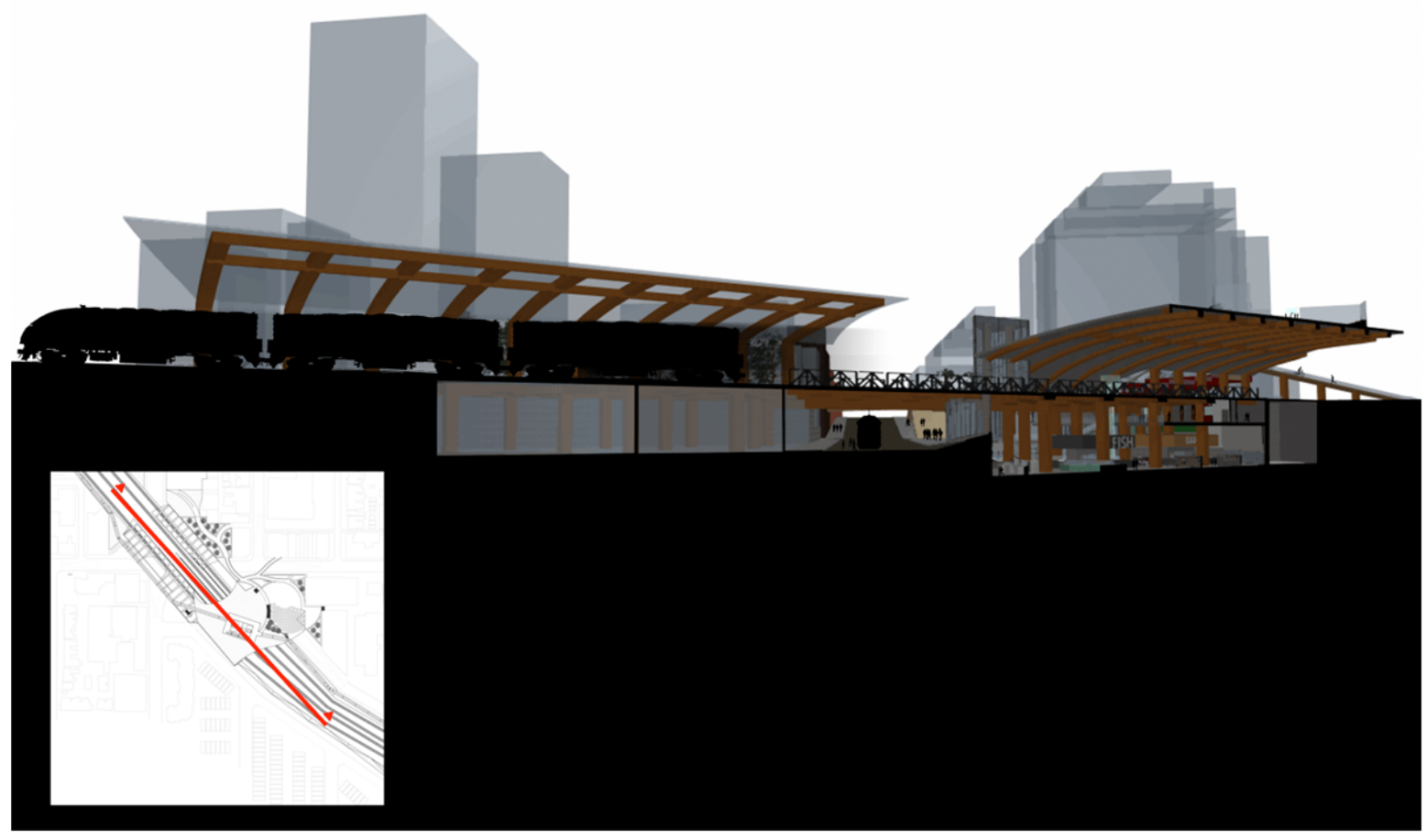

(84)

Figure 84 3D Section through CN Rail tracks

Shows $\mathrm{CN}$ train runs above the market hall and showing the structure that hold the train tracks 


\section{Thesis Conclusion}

This thesis illustrates a way of linking local cultures to global initiatives. It presents evidence supporting the argument that by using globa:local initiatives we can build more sustainable communities that are strongly backed by local cultures. Local cultures are pervasive across contemporary cities and there are fertile zones for growth. However, growth will not occur without the exploration and hybridization of emerging and multiple forces.

There is much we do not know about globa:local architecture. But what we do know is important. We know local cultures cluster. We know that local cultures endow places with value. We know that local cultures enrich cities and create jobs. This thesis shows us where this is happening and where it could be happening. It provides a device for identifying and leveraging the spatial concentrations and spatial pervasiveness of Toronto's local cultures and the next steps for the proposed design will involve further development of the outdoor components including:

- Articulate surface treatments, internal and external connections and textural qualities.

- Develop the relationship of proposed spaces to further activate the project and enhance its qualities as a public space. 
- Increase the level of continuity between the top surface and the subsurface.

- Embrace the notion of human activity and scale in order to design more engaging conditions.

So within this process, architects are required to facilitate the sustainable expansion of local cultures. Identifying growth areas is part of this process. Places may already be strong or they may have potential. It is the role of architects to identify places with potential and bring them to the global stage. This thesis shows that a renewed interest is needed into the origins of these studies in order to have a positive effect on local cultures. This thesis is the result of my observations during the past two years and further work is needed in this area. For instance, a detailed analysis of local cultures within Toronto may yield important knowledge about what makes these local cultures work and what could help them to work better.

It is hoped that this research creates a focus on the value of globa:local architecture as it contributes to the sustainability of local cultures. Therefore, it is important to establish nodes that allow for flexibility within the built structure. Each person belongs to a local culture and the need to have variety is essential for creating environments that generate interest in our lives. By ensuring flexibility, we ensure adaptability and create environments that are more susceptible to change. 
APPENDIX 


\section{Appendix A: Analysis of Toronto's Cultural Sector}

Toronto's cultural economy is expanding by leaps and bounds, outpacing other sectors. This fact has led the city to propose new strategies for sustaining its growth, and extending the economic and social opportunities it has created.

The following Cultural Location Index (CLI) is a composite measure that provides an overall picture of Toronto's cultural context. Breaking down the CLI into some of its components provides further details of where specific dimensions of the cultural economy are located. The maps I have in this section is courtesy of Martin Prosperity Institute and City of Toronto Website. 


\section{(a) Cultural Location Index: City Wide}

Figure 40 compares Toronto's census tracts on their CLI scores. Lighter grey indicates lower scores, while lime green indicates the highest scores. The map is highly revealing. Though the cultural sector - places where cultural workers live, work, and where there are cultural facilities - is concentrated downtown, it is also extensively dispersed across the city. North, south, east, and west, there are places with highly developed cultural economies. Every census tract in the city either had a cultural worker who lived and/or worked there or at a cultural facility. The cultural economy is built into the fabric of the entire city.

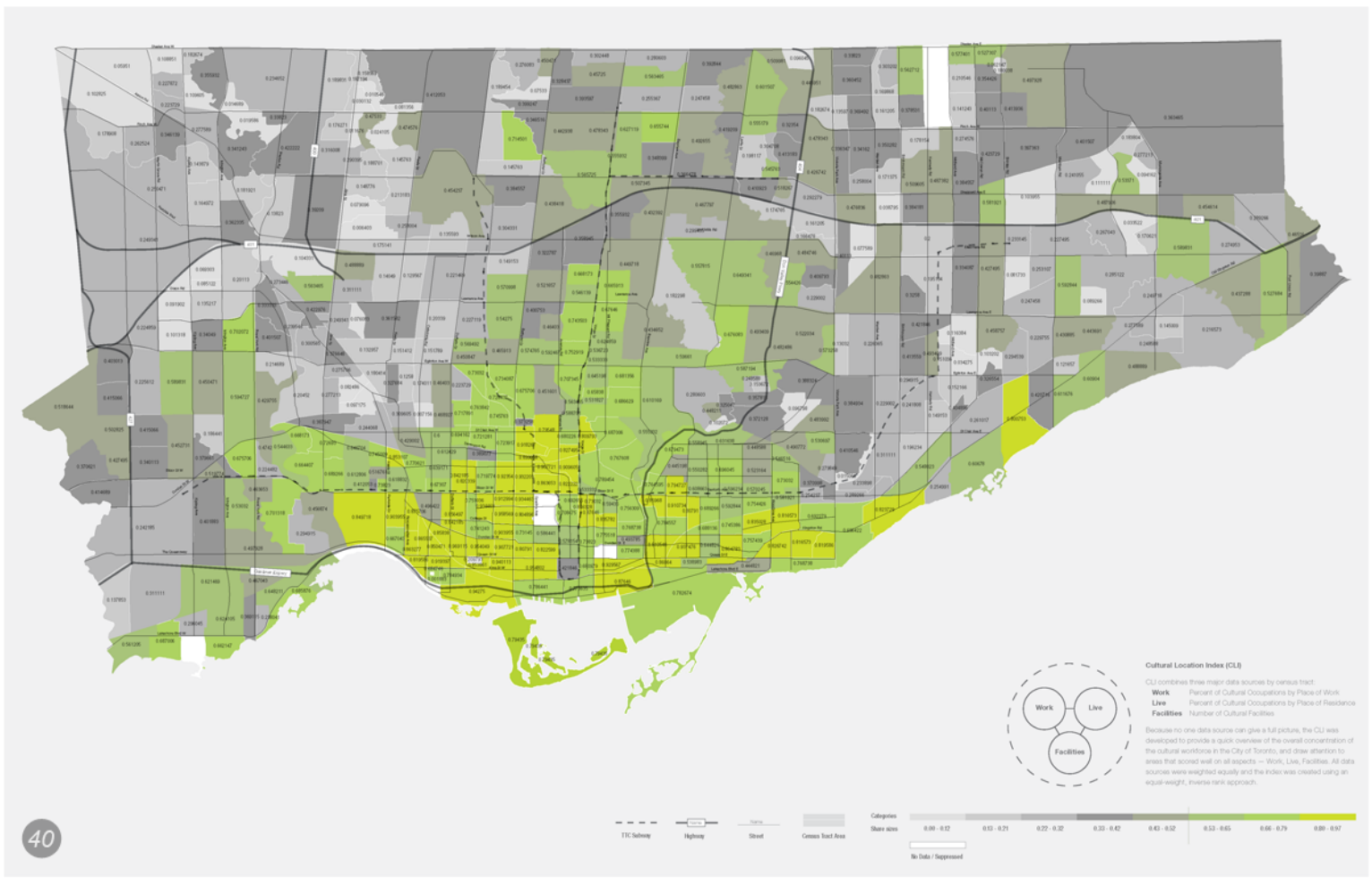

Figure 40 Cultural Location Index; from City of Toronto website, Courtesy of OCADU, 2010 


\section{(b) Cultural Location Index: Artists}

Figure 41 shows artists by place of work and place of residence. Each dot represents 12 artists who either live or work in the census tract. Blue dots indicate artist places of work; yellow indicate places of residence; and green indicate cases where the place of work and place of residence coincide.

Figure 41 shows that artists by both place of work and place of residence are located across the city. As in the case of cultural workers, more artists live in Toronto than work in Toronto. The total number of artists in Toronto by place of work $(18,130)$ is lower than artists in Toronto by place of residence $(22,600)$.

Figure 41 shows again that while there is a large concentration of artists downtown, they do not live and work only in the downtown core. Dots of all colors abound throughout Toronto. Some artists choose to both live and work amidst the bustle of the city centre. Others choose to live in the city, and work in the cultural sector, but do not live downtown. Yet artists typically live along public transportation lines providing access to downtown cultural jobs and connections to new ideas, a larger market, and collaborative and critical networks. Others work in cultural anchors outside the core (such as CTV Television Inc. in Scarborough), in small local firms, or in neighborhood home-workshops. 


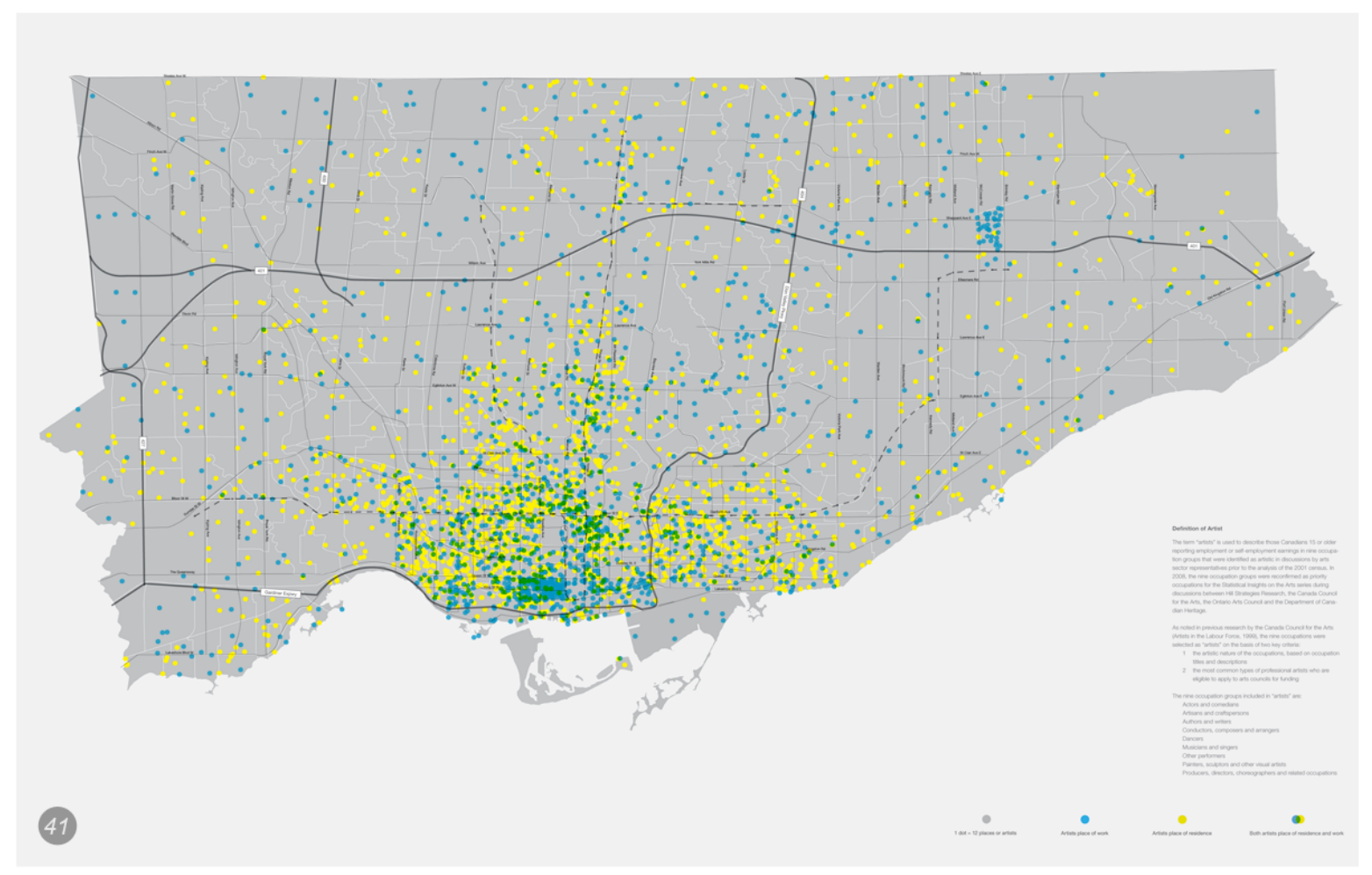

Figure 41 Artists Place of Work vs. Artists Place of Residence; from City of Toronto website, Courtesy of OCADU, 2010 


\section{(c) Cultural Location Index: Cultural Workers}

Figure 42 shows the top four places of work and the top 14 places of residence for the cultural sector for the whole city.

Figure 42 also reveals some specific features of the business composition in Toronto's centers of cultural employment. All four cultural work districts contain large national or international for-profit cultural businesses. Three out of the four contain a mix of small to mid-sized businesses that co-locate with the larger businesses. The map also shows important aspects of the occupational mix in the city's leading cultural work districts that would be otherwise invisible or conjectural. Key cultural occupations are concentrated across all four cultural work districts. Yet each district specializes in one specific area.

Figure 42 also shows the census tracts in which the most cultural workers live. These contain between 400-1,200 cultural workers each, or 16-21 per cent of the entire workforce who live in those census tracts.

Perhaps the most interesting result of this analysis is that the places where the most cultural workers live are not the same as where the most cultural workers are employed. This of course does not mean that cultural workers do not work in the pink areas, or that cultural workers do not live in the blue areas. They do. But overall, the highest concentrations are not the same, even if they are all relatively close to one another.

The residential clustering of cultural workers points to an important aspect of the cultural economy. By clustering in critical masses in residential neighborhoods, cultural workers create spillover effects for the communities in which they reside. When 20 per cent of the local residential population works in the arts and culture, neighborhoods often become alive with performances, exhibitions, workshops, informal gatherings, cafés, and other amenities. These not only stimulate aesthetic innovation among cultural producers themselves, but such clusters also generate buzzing scenes that draw visitors and sustain local businesses. 


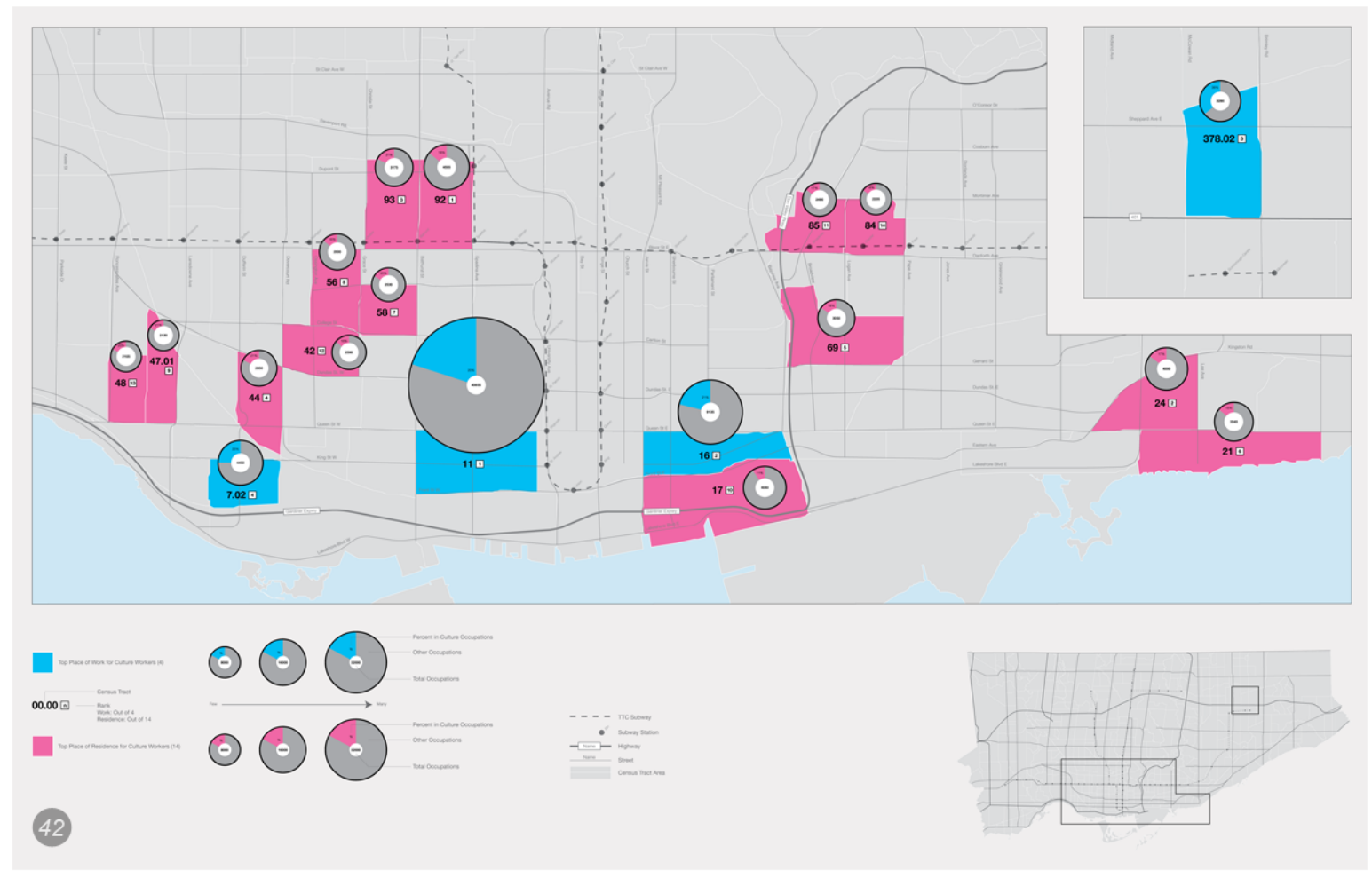

Figure 42 Cultural Workers Top Places of Work and Places of Residence; from City of Toronto website, Courtesy of OCADU, 2010 


\section{(d) Cultural Location Index: Cultural Facilities}

Figure 43 and 44 illustrate the location of cultural facilities in Toronto.

These maps show the relative concentrations of cultural facilities across the city. These two maps show just how strongly concentrated cultural facilities are in the downtown core.

This in itself is not surprising, as higher densities lead most services and businesses to concentrate in the city centre. More revealing is the fact that privately owned cultural facilities are for the most part located downtown and along the subways. City-owned facilities by contrast are more evenly dispersed across the city. Without City-owned facilities, many neighborhoods would likely lack local community access to cultural events and activities. 
43
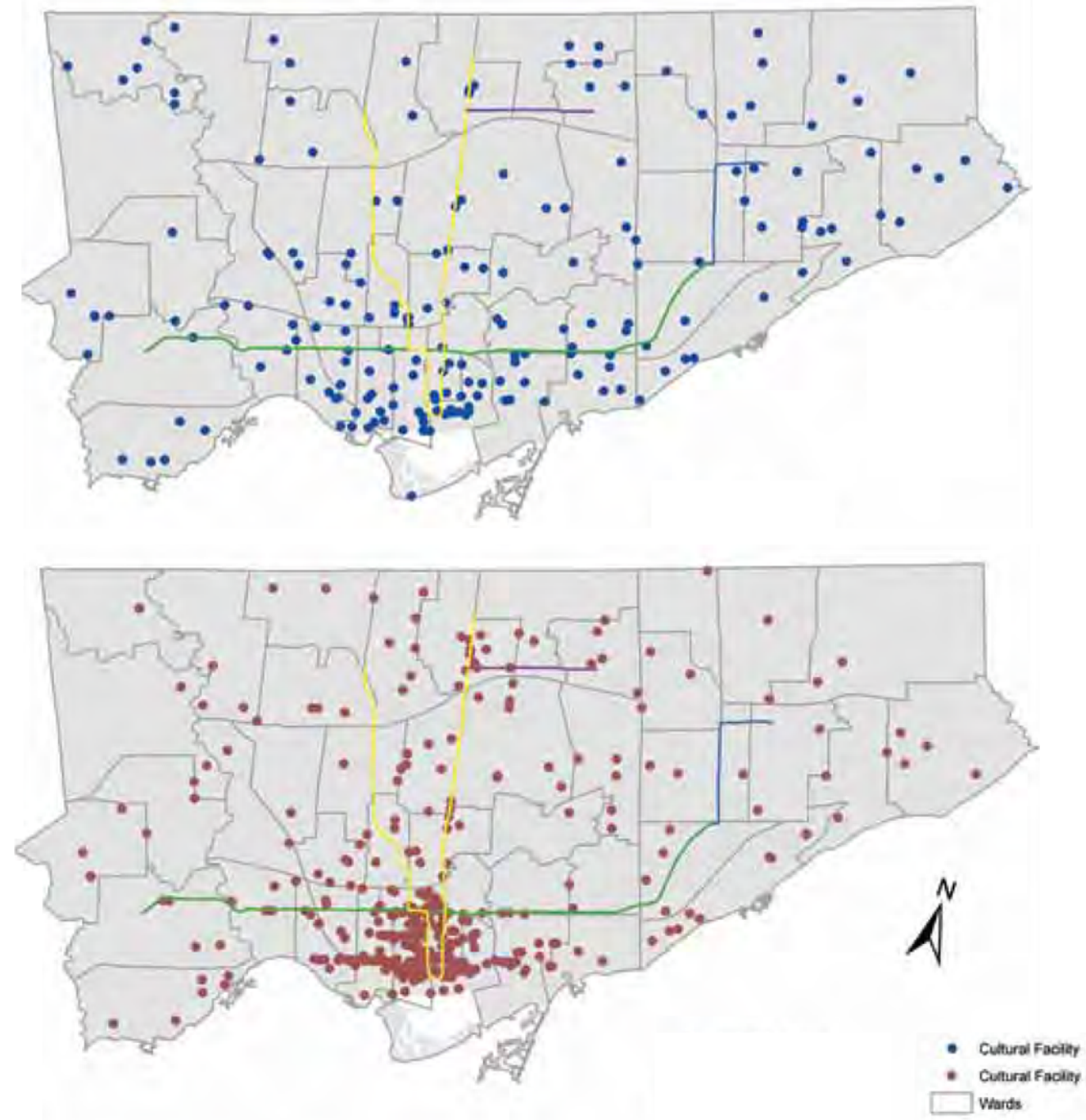

44

Figure 43

Cultural Facilities, City-Owned; Courtesy of Martin Prosperity Institute, 2010

Figure 44

Cultural Facilities, Owned by Others (Non-City Owned); Courtesy of Martin

Prosperity Institute, 2010 


\section{Appendix B: Table of Metrics}

A metrics is "an instrument or tool for evaluation, a yardstick to measure results and to assess realization of desired levels of performance in a sustained and objective way."1 Metrics help provide the evidence needed to support a thesis.

Metrics may be quantitative or qualitative. Quantitative metrics are statistical measures based on numerical or statistical facts. Qualitative metrics are language-based descriptions of cultural phenomenon. The following metrics includes both types of indicators because together, they develop a complete picture of the impacts of globa:local architecture. For instance, where quantitative metrics provide information about such things as numbers of participants, qualitative metrics can provide information about perceptions of participation.

1 Chapman, A., 2000, Indicators and Standards for Monitoring Economic, Social and Cultural Rights, Second Global Forum on Human Development, Brazil, 9-10 October 2000, retrieved from http://hdr.undp.org/docs/events/global_forum/2000/chapman.pdf. 


\section{Creating Quality Places Metrics}

\begin{tabular}{|c|c|c|}
\hline Indicator & Metric & Data Source \\
\hline Amount of open space & $\begin{array}{l}\text { The total hectares of } \\
\text { municipally owned open } \\
\text { space and total hectares } \\
\text { of municipally owned } \\
\text { open space per } 1,000 \\
\text { persons. }\end{array}$ & Municipal Annual Report \\
\hline Bike Paths & $\begin{array}{l}\text { The total kilometers of } \\
\text { designated bike } \\
\text { pathways or trails. }\end{array}$ & $\begin{array}{l}\text { Local - Parks and } \\
\text { Recreation Department }\end{array}$ \\
\hline Walkability & $\begin{array}{l}\text { The total number of } \\
\text { people who used walking } \\
\text { as the main means of } \\
\text { travel between home and } \\
\text { their place of work. }\end{array}$ & $\begin{array}{l}\text { Statistics Canada. } 2006 . \\
\text { Place of work highlight } \\
\underline{\text { tables, } 2006 \text { Census }} \\
\text { Every } 5 \text { years. }\end{array}$ \\
\hline $\begin{array}{l}\text { Sustainable } \\
\text { transportation use }\end{array}$ & $\begin{array}{l}\text { The total number of } \\
\text { people who used } \\
\text { sustainable modes of } \\
\text { transportation as their } \\
\text { main means to travel } \\
\text { between home and their } \\
\text { place of work. }\end{array}$ & $\begin{array}{l}\text { Statistics Canada. } 2006 . \\
\text { Place of work highlight } \\
\text { tables, } 2006 \text { Census } \\
\text { Every } 5 \text { years. }\end{array}$ \\
\hline
\end{tabular}




\section{Strengthening Social Cohesion Metrics}

\begin{tabular}{|c|c|c|}
\hline Indicator & Metric & Data Source \\
\hline $\begin{array}{l}\text { Outdoor recreation } \\
\text { facility space }\end{array}$ & $\begin{array}{l}\text { The total square metres } \\
\text { of municipally owned } \\
\text { outdoor recreation facility } \\
\text { space and total square } \\
\text { metres of municipally } \\
\text { owned outdoor recreation } \\
\text { facility space per } 1,000 \\
\text { persons. }\end{array}$ & Municipal Annual Report \\
\hline $\begin{array}{l}\text { Number and seasonal } \\
\text { distribution of } \\
\text { celebrations and } \\
\text { festivals }\end{array}$ & $\begin{array}{l}\text { Total number of permits } \\
\text { for celebrations and } \\
\text { festivals issued by the } \\
\text { municipality. }\end{array}$ & $\begin{array}{l}\text { Local Facilities } \\
\text { Management Depart- } \\
\text { ment; Parks and } \\
\text { Recreation Department; } \\
\text { Permitting; Licensing }\end{array}$ \\
\hline $\begin{array}{l}\text { Number of celebrations } \\
\text { and festivals funded by } \\
\text { the municipality }\end{array}$ & $\begin{array}{l}\text { The number of } \\
\text { celebrations and festivals } \\
\text { that are funded by the } \\
\text { municipality. }\end{array}$ & $\begin{array}{l}\text { Local Facilities } \\
\text { Management Depart- } \\
\text { ment; Parks and } \\
\text { Recreation Department; } \\
\text { Permitting; }\end{array}$ \\
\hline $\begin{array}{l}\text { Number of community } \\
\text { cultural organizations } \\
\text { funded by the } \\
\text { municipality }\end{array}$ & $\begin{array}{l}\text { The number of } \\
\text { community cultural orga- } \\
\text { nizations funded by the } \\
\text { municipality. }\end{array}$ & $\begin{array}{l}\text { Local Culture } \\
\text { Department/Dependent } \\
\text { on local data }\end{array}$ \\
\hline $\begin{array}{l}\text { Accessibility of arts, } \\
\text { culture and heritage } \\
\text { offerings }\end{array}$ & $\begin{array}{l}\text { Track responses to the } \\
\text { survey question "Do you } \\
\text { feel that arts, culture and } \\
\text { heritage offerings are } \\
\text { physically, financially and } \\
\text { geographically accessible } \\
\text { to you?" }\end{array}$ & $\begin{array}{l}\text { Local survey/Dependent } \\
\text { on local data }\end{array}$ \\
\hline $\begin{array}{l}\text { Estimated volunteer } \\
\text { participation in } \\
\text { community cultural } \\
\text { organizations and } \\
\text { cultural events, }\end{array}$ & $\begin{array}{l}\text { Estimated number of } \\
\text { volunteers, and volunteer } \\
\text { hours at municipal and } \\
\text { municipally-funded } \\
\text { community cultural }\end{array}$ & Local Culture Department \\
\hline
\end{tabular}




\begin{tabular}{|c|c|c|}
\hline $\begin{array}{l}\text { celebrations and fes- } \\
\text { tivals }\end{array}$ & $\begin{array}{l}\text { organizations and cultural } \\
\text { events, celebrations and } \\
\text { festivals. Multiply total } \\
\text { number of volunteer } \\
\text { hours } x \$ 22.38 \text {. }\end{array}$ & \\
\hline Public Art & $\begin{array}{l}\text { The total number of public } \\
\text { art commissions by } \\
\text { municipality. } \\
\text { The total value of those } \\
\text { public art commissions. } \\
\text { The total dollars spent on } \\
\text { artist professional fees as } \\
\text { a percentage of the total } \\
\text { value of the commission. } \\
\text { The total dollars spent } \\
\text { within other areas of local } \\
\text { economy as a percentage } \\
\text { of the total (eg, } \\
\text { subcontractors, materials } \\
\text { and supplies). }\end{array}$ & Local Culture Department \\
\hline Trip Activities & $\begin{array}{l}\text { Total number of trip } \\
\text { activities undertaken } \\
\text { when visiting a particular } \\
\text { place, by category. } \\
\text { Categories included are: } \\
\text { festivals/fairs; cultural } \\
\text { performances; } \\
\text { museums/art galleries; } \\
\text { zoos/aquariums; sports } \\
\text { events; casinos; theme } \\
\text { parks; national/provincial } \\
\text { nature parks; historic } \\
\text { sites; any outdoor/sports } \\
\text { activity (subdivided into: } \\
\text { boating; golfing; fishing; } \\
\text { hunting; downhill } \\
\text { skiing/snowboarding.) }\end{array}$ & $\begin{array}{l}\text { Ministry of Tourism and } \\
\text { Culture Regional Tourism } \\
\text { Profiles. } \\
\text { Ministry of Tourism and } \\
\text { Culture Regional Tourism } \\
\text { Profiles. }\end{array}$ \\
\hline
\end{tabular}


Economic Activity Metrics

\begin{tabular}{|c|c|c|}
\hline Indicator & Metric & Data Source \\
\hline $\begin{array}{l}\text { Number of businesses in } \\
\text { the culture sector }\end{array}$ & $\begin{array}{l}\text { Total number of } \\
\text { businesses in each of the } \\
\text { cultural industries } \\
\text { included in the culture } \\
\text { sector, according to } \\
\text { NAICS codes. Total } \\
\text { number of businesses in } \\
\text { all cultural industries in } \\
\text { the culture sector. }\end{array}$ & $\begin{array}{l}\text { Statistics Canada. } \\
\text { CBP Database } \\
\text { Semi Annually }\end{array}$ \\
\hline $\begin{array}{l}\text { Number of "outdoor } \\
\text { activities" businesses }\end{array}$ & $\begin{array}{l}\text { Total number of } \\
\text { businesses in each of the } \\
\text { industries included in } \\
\text { "outdoor activities", } \\
\text { according to NAICS } \\
\text { codes. Total number of } \\
\text { businesses in all "outdoor } \\
\text { activities" industries. }\end{array}$ & $\begin{array}{l}\text { Statistics Canada. } \\
\text { CBP Database } \\
\text { Semi Annually }\end{array}$ \\
\hline $\begin{array}{l}\text { Number of workers in } \\
\text { cultural industries }\end{array}$ & $\begin{array}{l}\text { Total number of workers } \\
\text { in cultural industries. Add } \\
\text { total number of workers } \\
\text { in each of the cultural } \\
\text { industries at a four-digit } \\
\text { NAICS code level. }\end{array}$ & $\begin{array}{l}\text { Statistics Canada, } 2006 \\
\text { Census of Population, } \\
\text { Statistics Canada } \\
\text { catalogue no. } 97-559- \\
\text { XCB2006009 (Canada, } \\
\text { Code01). } \\
\frac{\text { Industry by North }}{\text { American Industry }} \\
\underline{\text { Classification System }} \\
\underline{(2002)} \\
\text { Every } 5 \text { years }\end{array}$ \\
\hline $\begin{array}{l}\text { Number of workers with } \\
\text { cultural occupations }\end{array}$ & $\begin{array}{l}\text { Total number of workers } \\
\text { with cultural occupations. } \\
\text { Add total number of } \\
\text { workers in each of the } \\
\text { cultural occupations, } \\
\text { according to NOCS } \\
\text { codes. }\end{array}$ & $\begin{array}{l}\text { Statistics Canada, } 2006 \\
\text { Census of Population, } \\
\text { Statistics Canada } \\
\text { catalogue no. } 97-559- \\
\text { XCB2006011 (Canada, } \\
\text { Code01) } \\
\text { Occupation by National } \\
\text { Occupational } \\
\text { Classification } \\
\text { Every } 5 \text { years }\end{array}$ \\
\hline Number of visitors & $\begin{array}{l}\text { Total number of person } \\
\text { visits to the municipality } \\
\text { in a year. (Data is also }\end{array}$ & $\begin{array}{l}\text { Ministry of Tourism and } \\
\text { Culture Regional Tourism } \\
\text { Profiles. See Table 1.1: }\end{array}$ \\
\hline
\end{tabular}




\begin{tabular}{|l|l|l|}
\hline & $\begin{array}{l}\text { available by breakdown } \\
\text { of overnight and same } \\
\text { day visits.) }\end{array}$ & $\begin{array}{l}\text { Person visits: Length of } \\
\text { Stay } \\
\text { Ministry of Tourism and }\end{array}$ \\
\hline Visitor Spending & $\begin{array}{l}\text { Culture Regional Tourism } \\
\text { Profiles. } \\
\text { Annually }\end{array}$ \\
& $\begin{array}{l}\text { Total amount of spending } \\
\text { by visitors in dollars. } \\
\text { speakdown of culture } \\
\text { spending and recreation } \\
\text { interest, although there } \\
\text { are no definitions } \\
\text { provided for these } \\
\text { categories.) }\end{array}$ & $\begin{array}{l}\text { Ministry of Tourism and } \\
\text { Culture Regional Tourism } \\
\text { Profiles. See Table 1.11: } \\
\text { Total Visitor Spending. } \\
\text { Ministry of Tourism and }\end{array}$ \\
\hline $\begin{array}{l}\text { Culture Regional Tourism } \\
\text { Profiles. }\end{array}$ \\
\hline
\end{tabular}


Organizational Metrics

\begin{tabular}{|c|c|c|}
\hline Indicator & Metric & Data Source \\
\hline Transit Use & $\begin{array}{l}\text { The total number of } \\
\text { people who used public } \\
\text { transit as the main } \\
\text { means of travel between } \\
\text { home and their place of } \\
\text { work. }\end{array}$ & $\begin{array}{l}\text { Statistics Canada, } 2006 . \\
\text { Place of work highlight } \\
\underline{\text { tables, } 2006 \text { Census }} \\
\text { Every } 5 \text { years. }\end{array}$ \\
\hline Housing condition & $\begin{array}{l}\text { The total number of } \\
\text { households (including } \\
\text { renters, owners, band } \\
\text { housing) in need of } \\
\text { regular maintenance. } \\
\text { The total number of } \\
\text { households (including } \\
\text { renters, owners, band } \\
\text { housing) in need of minor } \\
\text { repairs. } \\
\text { The total number of } \\
\text { households (including } \\
\text { renters, owners, band } \\
\text { housing) in need of major } \\
\text { repairs. }\end{array}$ & $\begin{array}{l}\text { Statistics Canada, } 2006 . \\
\text { Shelter costs highlight } \\
\underline{\text { tables, } 2006 \text { Census }} \\
\text { Every } 5 \text { years }\end{array}$ \\
\hline Diversity & $\begin{array}{l}\text { The percentage of } \\
\text { persons who are } \\
\text { identified as visible } \\
\text { minorities. Total visible } \\
\text { minority population } \\
\text { divided by total } \\
\text { population. }\end{array}$ & $\begin{array}{l}\text { Statistics Canada. } \\
\text { Catalogue no. 92-591- } \\
\text { XWE. Ottawa, Ontario. } \\
\text { Under visible minority } \\
\text { population } \\
\text { characteristics, see Total } \\
\text { visible minority } \\
\text { population. } \\
2006 \text { Community Profiles } \\
\text { Every } 5 \text { years }\end{array}$ \\
\hline
\end{tabular}




\section{Fostering Creativity Metrics}

\begin{tabular}{|c|c|c|}
\hline Indicator & Metric & Data Source \\
\hline $\begin{array}{l}\text { Percentage of residents } \\
\text { satisfied with arts, culture } \\
\text { and heritage offerings }\end{array}$ & $\begin{array}{l}\text { Track responses to the } \\
\text { survey question: "How } \\
\text { satisfied are you with the } \\
\text { selection of arts, culture } \\
\text { and heritage offerings in } \\
\text { your municipality?" Count } \\
\text { the number choosing } \\
\text { 'somewhat' or 'very } \\
\text { satisfied' and divide by the } \\
\text { total number of } \\
\text { respondents with an } \\
\text { opinion. }\end{array}$ & $\begin{array}{l}\text { Local survey/Dependent } \\
\text { on local data }\end{array}$ \\
\hline $\begin{array}{l}\text { Number of residents who } \\
\text { consider themselves } \\
\text { artists }\end{array}$ & $\begin{array}{l}\text { Track total number of yes } \\
\text { responses to the survey } \\
\text { question "Do you consider } \\
\text { yourself to be an artist? If } \\
\text { yes, do you consider } \\
\text { yourself: a) professional or } \\
\text { b) amateur? Are you }\end{array}$ & $\begin{array}{l}\text { Local survey/Dependent } \\
\text { on local data }\end{array}$ \\
\hline $\begin{array}{l}\text { Number of artists involved } \\
\text { in capital projects }\end{array}$ & $\begin{array}{l}\text { The total number of artists } \\
\text { involved in municipal } \\
\text { capital projects (that are } \\
\text { not generally considered } \\
\text { public art). }\end{array}$ & $\begin{array}{l}\text { Local Culture } \\
\text { Department/Dependent on } \\
\text { local data }\end{array}$ \\
\hline $\begin{array}{l}\text { Estimated volunteer } \\
\text { participation in community } \\
\text { cultural organizations and } \\
\text { cultural events, } \\
\text { celebrations and festivals }\end{array}$ & $\begin{array}{l}\text { Estimated number of } \\
\text { volunteers, and volunteer } \\
\text { hours at municipal and } \\
\text { municipally-funded } \\
\text { community cultural organi- } \\
\text { zations and cultural } \\
\text { events, celebrations and } \\
\text { festivals. Multiply total } \\
\text { number of volunteer hours } \\
x \$ 22.38 \text {. }\end{array}$ & $\begin{array}{l}\text { Local Culture Department; } \\
\text { Volunteer hourly rate in } \\
2011 \text { (Rate of } \\
\$ 22.38 / \mathrm{hr}) 13 / \text { Dependent } \\
\text { on local data }\end{array}$ \\
\hline
\end{tabular}




\section{Appendix C: Other Design Explorations}

Design exploration is a powerful approach for designing and understanding the design process. Since August 2011 I started series of design exploration that have given me great advantage to design the final design proposal. I have included these mini projects for you to review to realize the string of thoughts.

Artists in Residence

Understanding Pomegranate
Page 121

Page 125 
Appendix C: $\quad$ Artists in Residence 


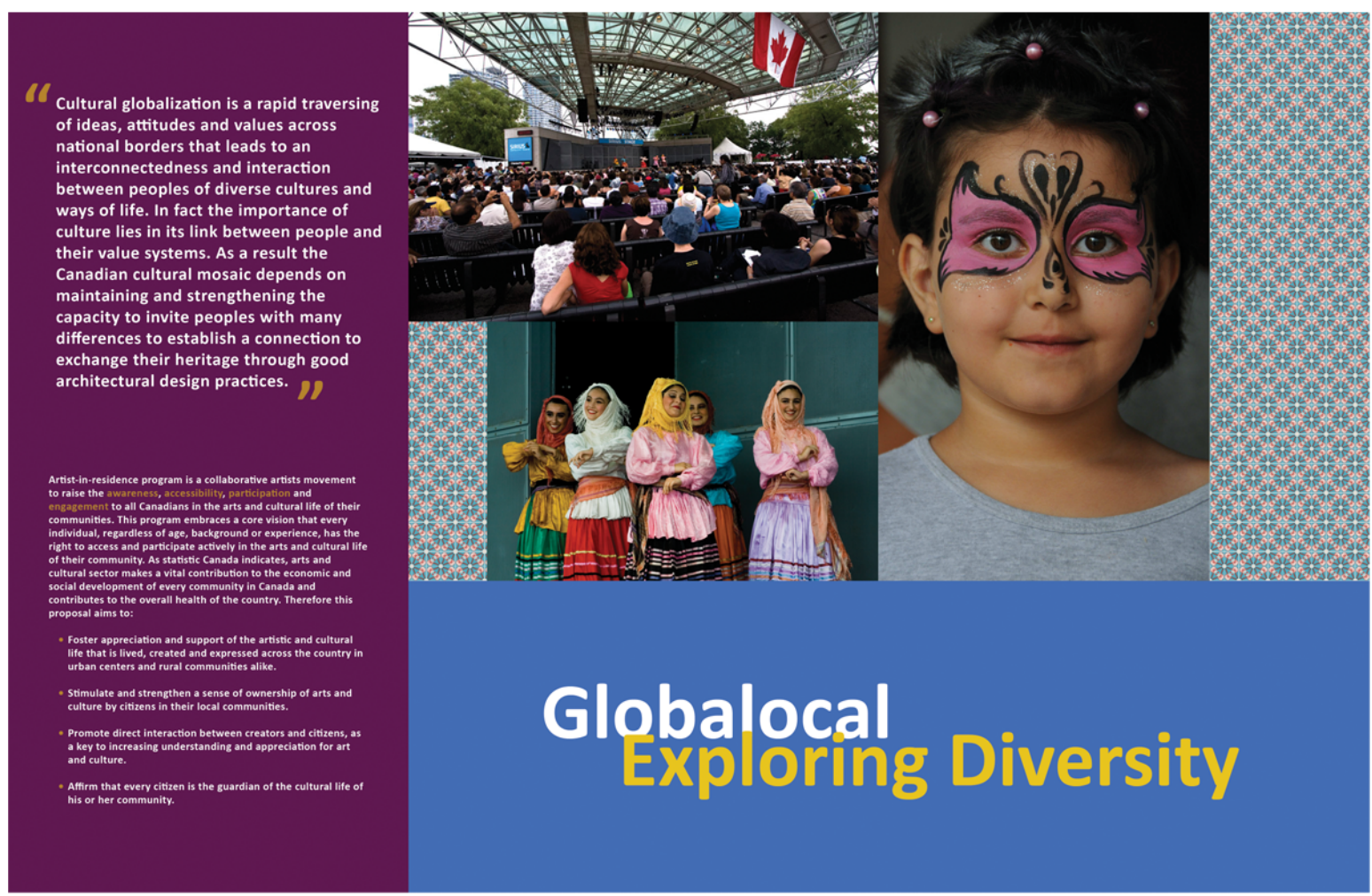




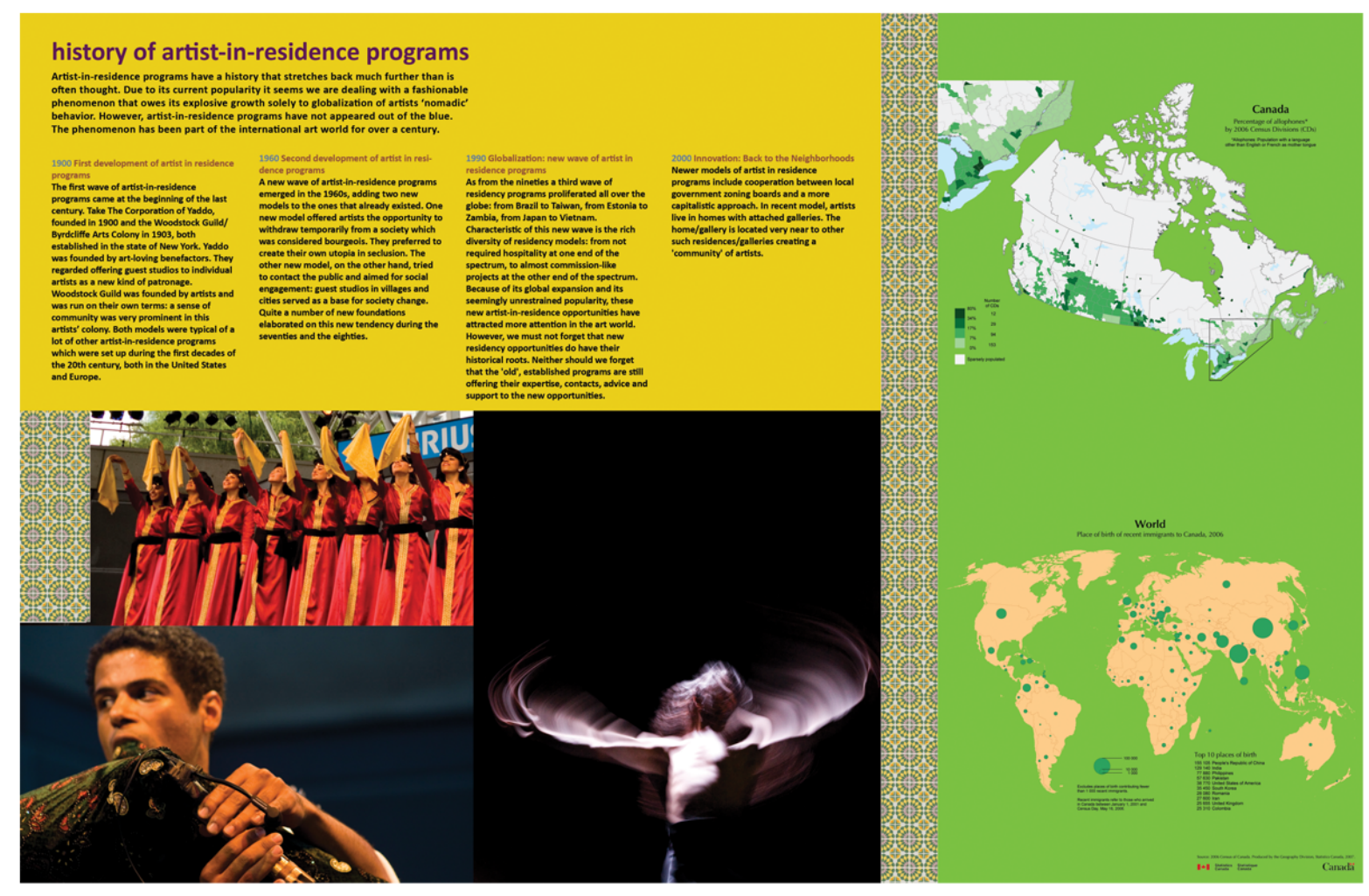



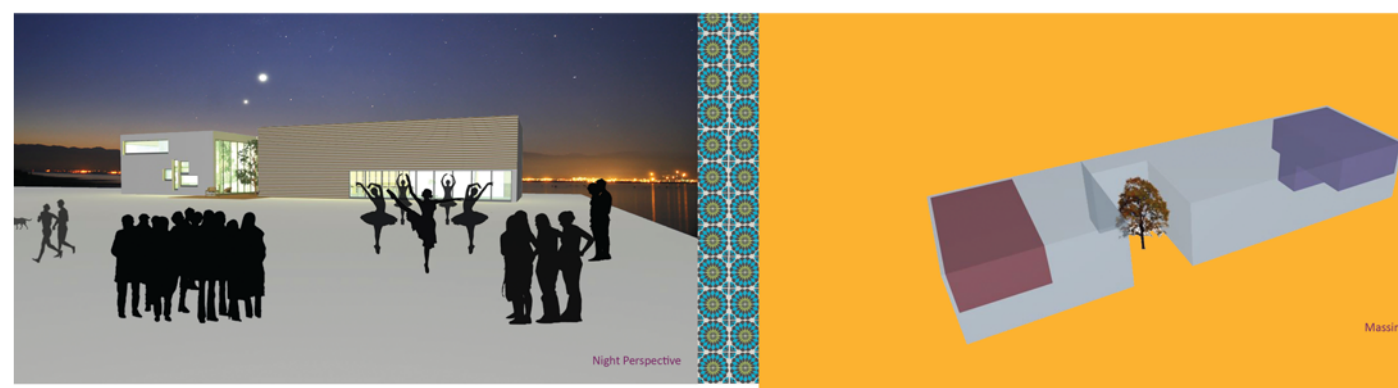

studio home for artist-in-residence program

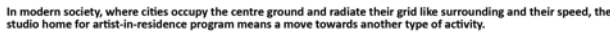

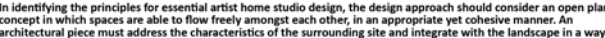

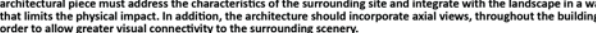

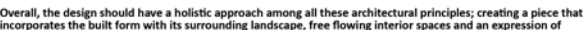

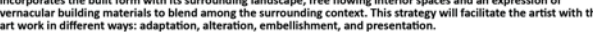
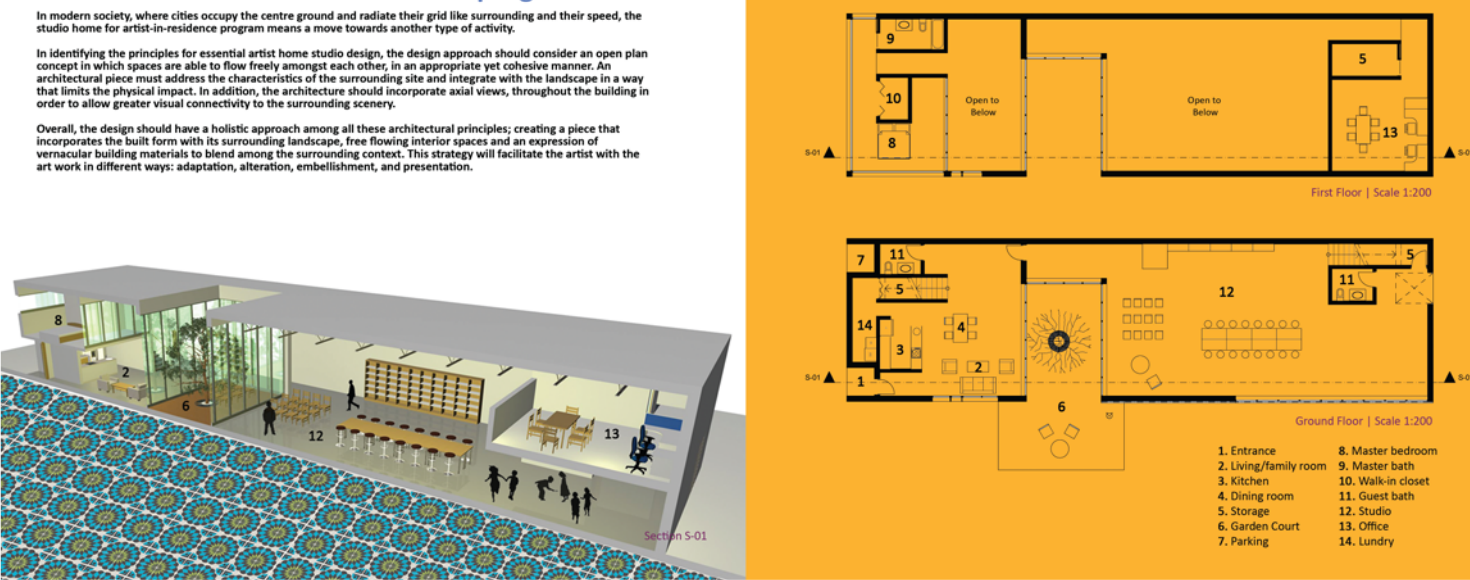
Appendix C: Understanding Pomegranate 

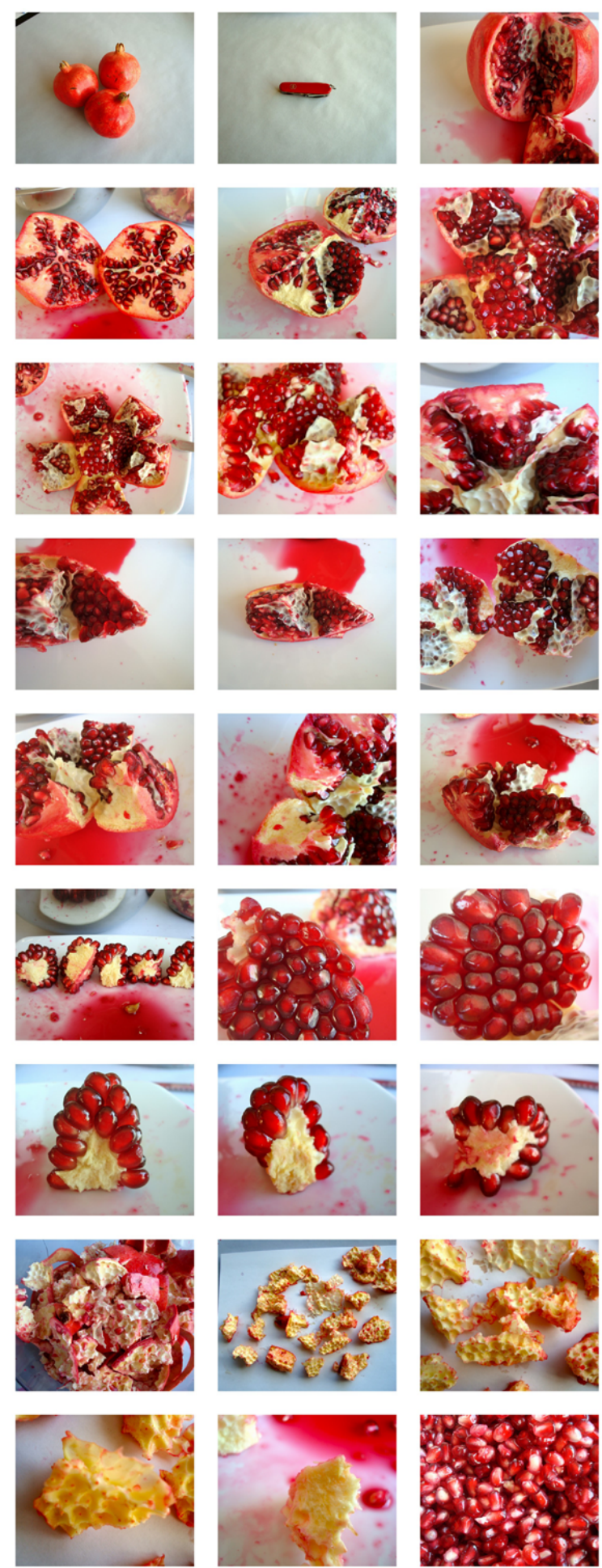
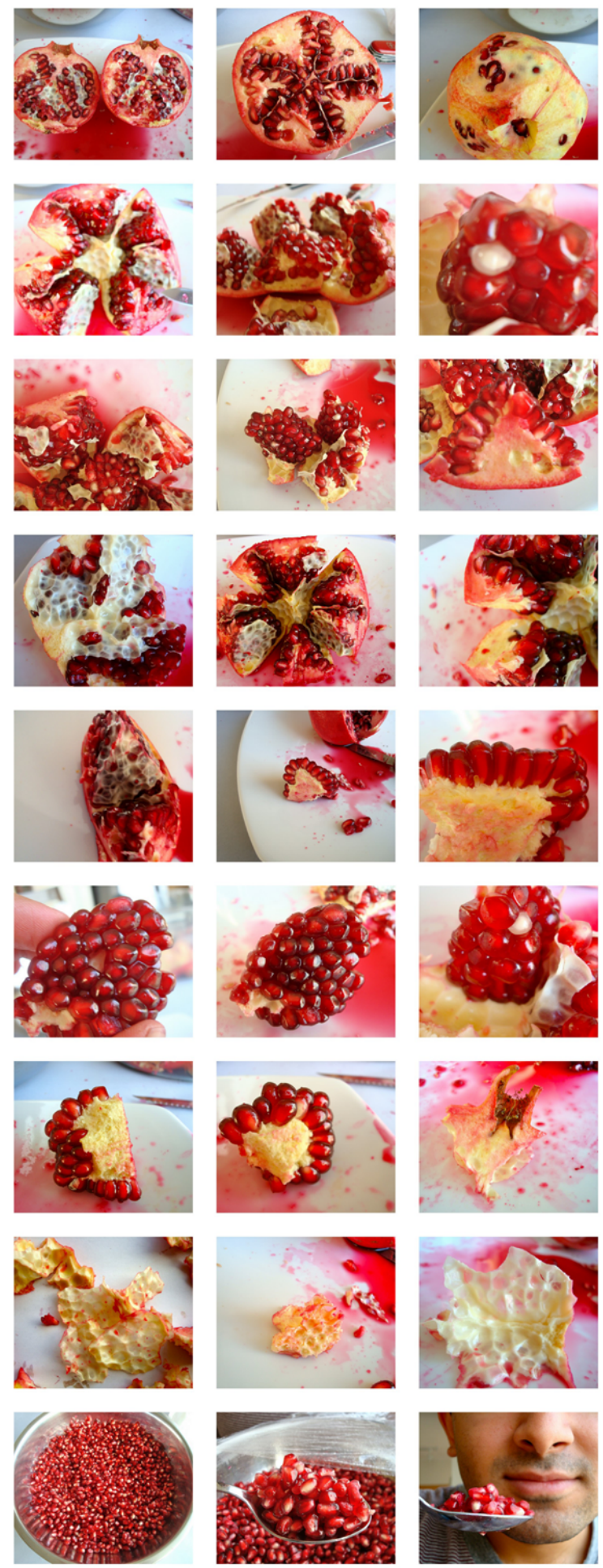


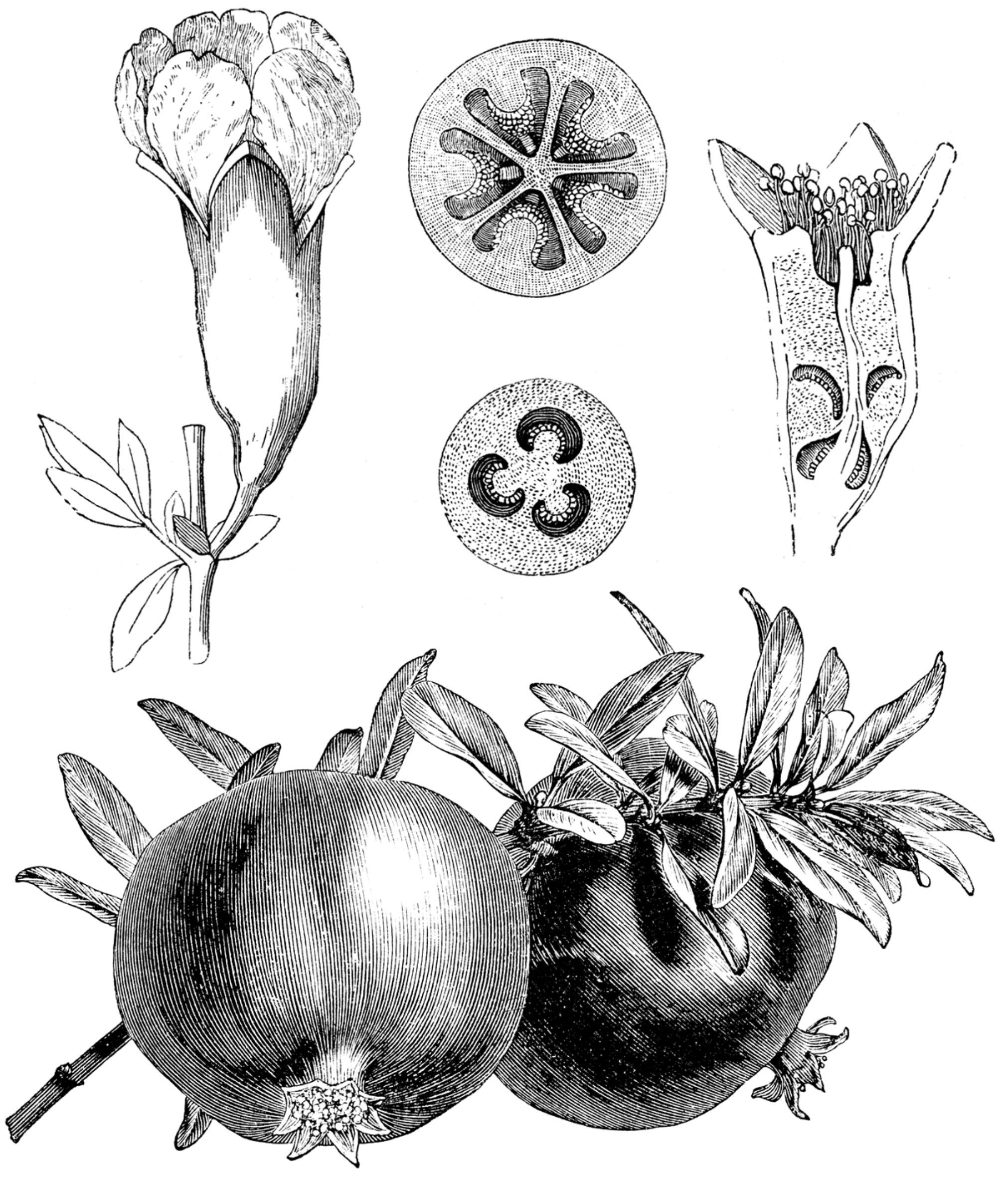




\section{Geometric Exercises}

In order to engaged with my thesis about the relationship between the hybridization of multiple forces and materials, I ran a series of geometric exercises in order to better understand the concept of being unique (local) whilst at the same time being compliant with pluralistic rules (global).

I deconstructed a pomegranate in order to learn from its internal organizational structure and clusters. I removed all the physical traces of the pomegranate as a form giver (while maintaining it as a virtual/conceptual reference system), and reorganized them to propose an alternative archetype for a glob:local architecture.

\subsection{Pomegranate}

The pomegranate is an edible fruit that has a rounded hexagonal shape and a thick pastel magenta skin. It is classified as a berry and has a diameter of 5 to $12 \mathrm{~cm}$, which makes it between a lemon and a grapefruit in size. The number of seeds in a pomegranate can vary from approximately 200 to 1400 , with each seed surrounded by a water-laden pulp ranging in color from white to deep red or purple. (Figure 36)

The internal architecture of a pomegranate is an amazing testament to local culture. The structure, complex and compact, contains hundreds of individual parts, of at least a dozen different tissues, mixed in an asymmetric symphony order. 

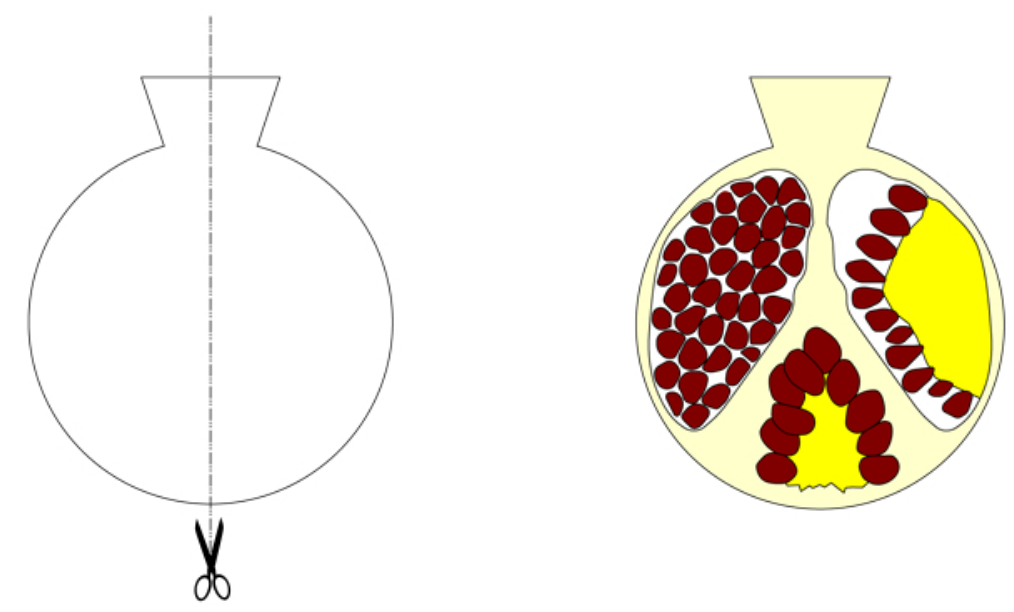

37
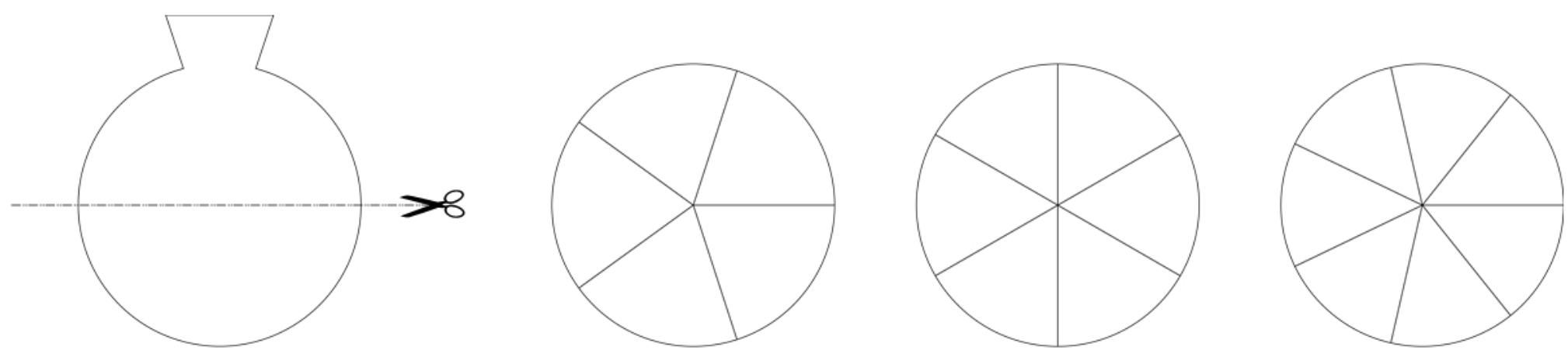

38

37 Longitudinal Section

38 Transverse Section

129 


\subsection{Longitudinal Section}

When cut longitudinally, the fruit is seen to be divided into a series of six cavities, in each of which the seeds are irregularly arranged. (Figure 37)

\subsection{Transverse Section}

When cut transversely, the fruit is seen to be divided by a membrane into an upper and lower portion. Based on my research, there are 3 types of internal organization. (Figure 38)

1. Having five edges (Pentagon)

2. Having six edges (Hexagon)

3. Having seven edges (Heptagon) 


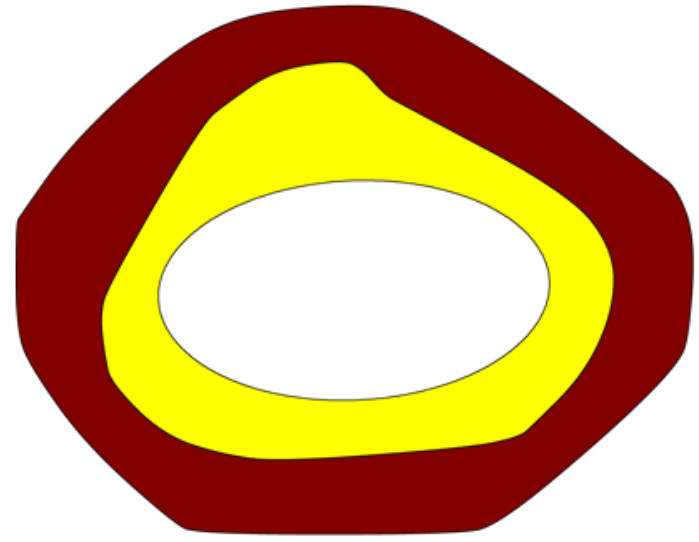

39

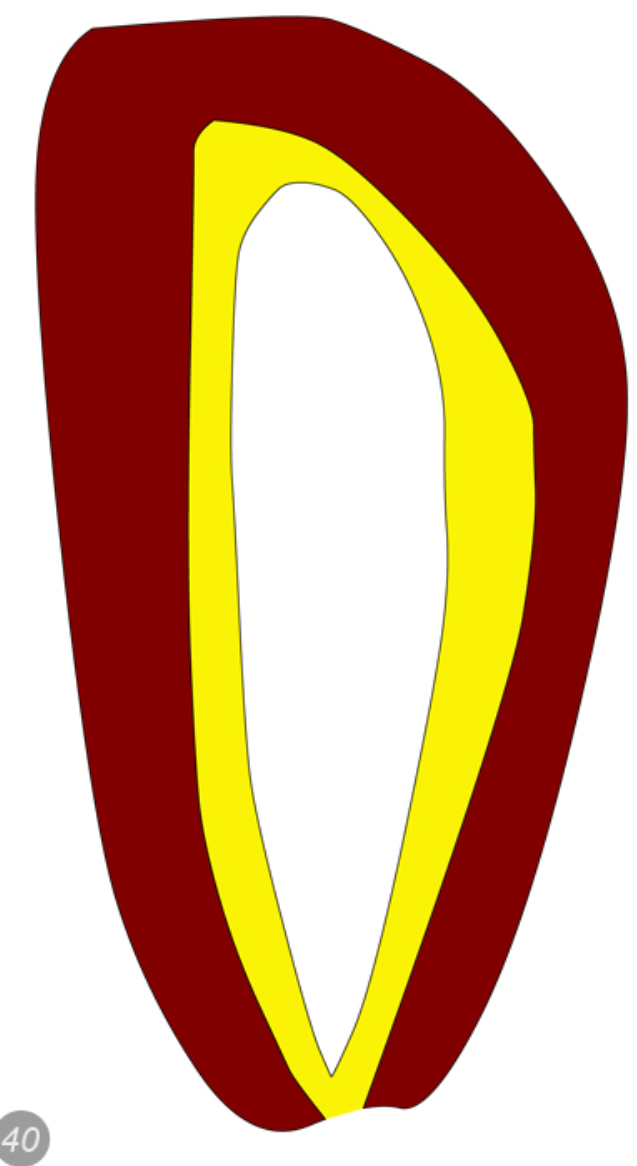

39 Pomegranate seed longitudinal section 40 Pomegranate seed transverse section 


\subsection{Seeds}

Based on the statistics produced by Alexander Haubold, each pomegranate has an average of 613 seeds. Every seed has a center point and radius that represent the required space for a seed. The seeds are about $12 \mathrm{~mm}$. long, subpyramidal in shape, and contain a sweetish acidulous juice in a translucent outer portion. (Figure 39-40)

\begin{tabular}{|l|l|l|l|l|l|l|l|}
\hline Country & $\begin{array}{c}\text { Sample } \\
\text { Size }\end{array}$ & $\begin{array}{c}\text { Min } \\
\text { No. } \\
\text { Seeds }\end{array}$ & $\begin{array}{c}\text { Max } \\
\text { No. } \\
\text { Seeds }\end{array}$ & $\begin{array}{c}\text { Avr } \\
\text { No. } \\
\text { Seeds }\end{array}$ & $\begin{array}{c}\text { Min } \\
\text { Weight } \\
(\mathrm{g})\end{array}$ & $\begin{array}{c}\text { Max } \\
\text { Weight (g) }\end{array}$ & $\begin{array}{c}\text { Avr } \\
\text { Weight } \\
(\mathrm{g})\end{array}$ \\
\hline USA & 150 & 286 & 1370 & 680 & 145 & 1065 & 421 \\
\hline Singapore & 2 & 339 & 579 & 459 & 250 & 400 & 325 \\
\hline Iran & 37 & 165 & 1263 & 338 & 200 & 660 & 354 \\
\hline Spain & 2 & 580 & 837 & 709 & 280 & 330 & 305 \\
\hline Turkey & 12 & 267 & 971 & 576 & 226 & 1001 & 603 \\
\hline Brazil & 3 & 647 & 1054 & 809 & 568 & 658 & 599 \\
\hline & & 165 & 1370 & 613 & 145 & 1065 & 420 \\
\hline
\end{tabular}

Table 1.1: Pomegranate Statistics

Source: http://www.aquaphoenix.com/misc/pomegranate/ 
Seed

Centre Point

Connecting Line to Neighboring Seeds

Connecting Line Between Seeds

Void

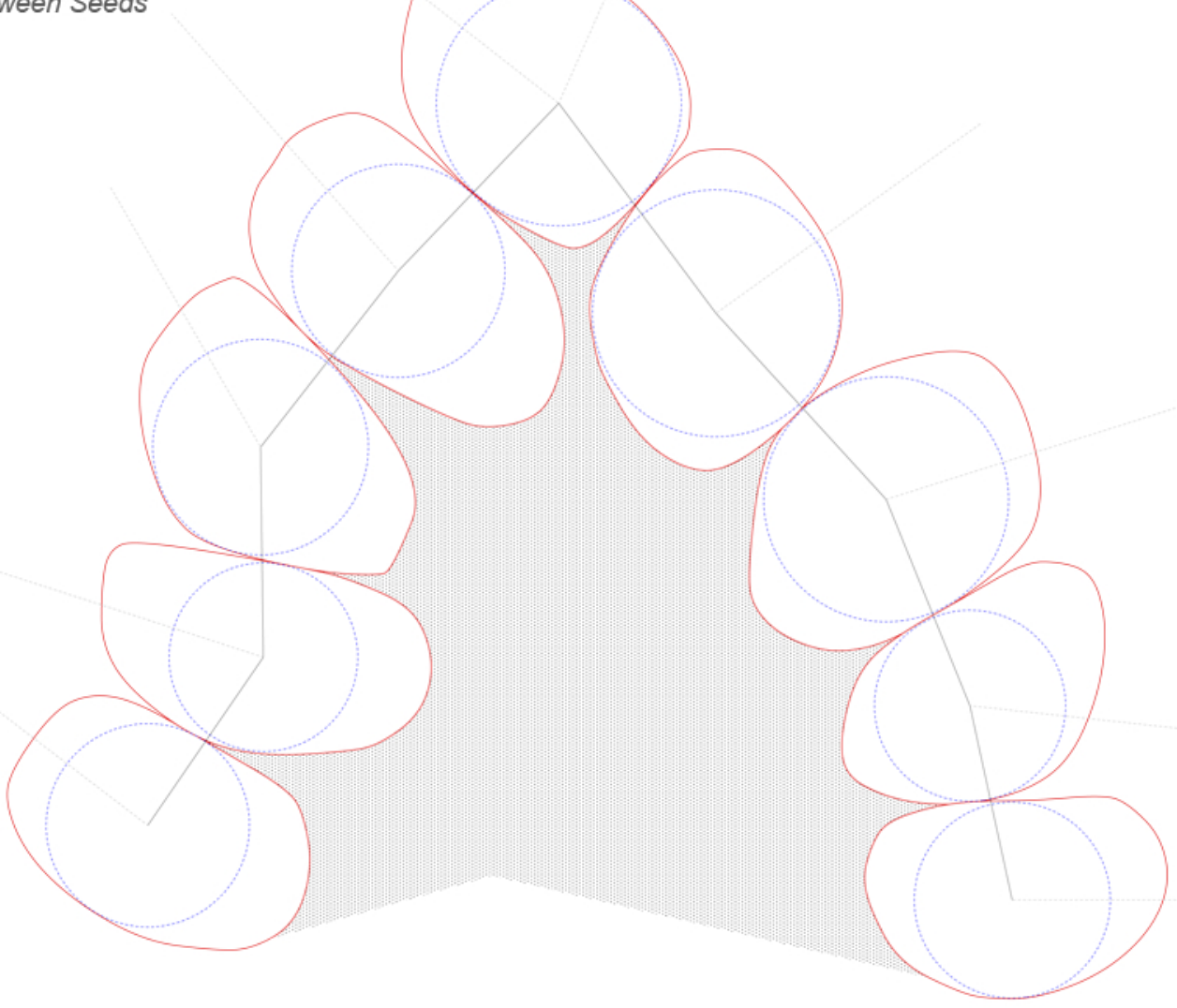

41 Pomegranate Seeds vs. Voids 


\subsection{Voids Between Seeds}

A point without a circle around it is a representation of a void, or any other form of space that is dedicated to additional spaces. (Figure 41)

\subsection{Connecting Lines}

Seeds and voids can be connected by lines. A solid line represents a physical connection, which is direct, and one can move from one seed to another. A dotted line represents partial connection or any other form that usually does not pass through but still can be seen. (Figure 41) 


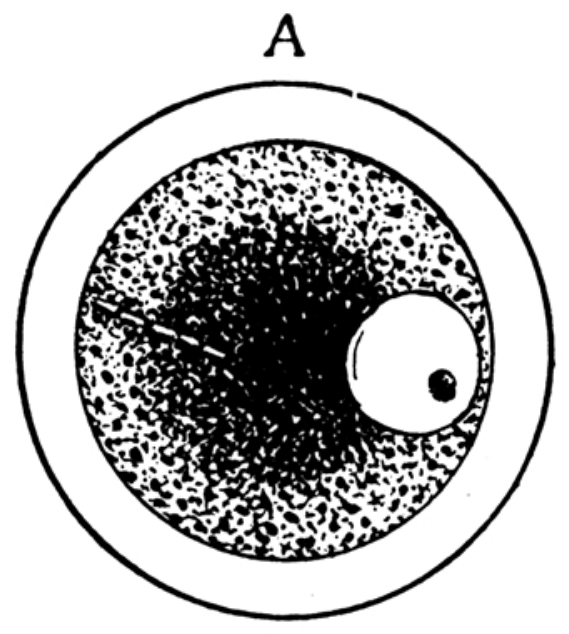

D

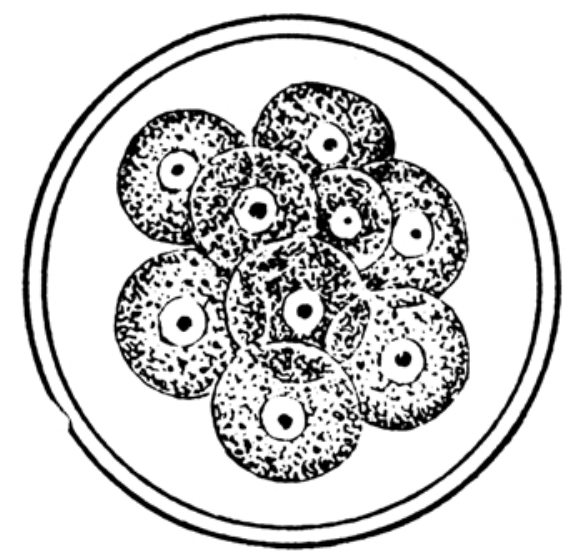

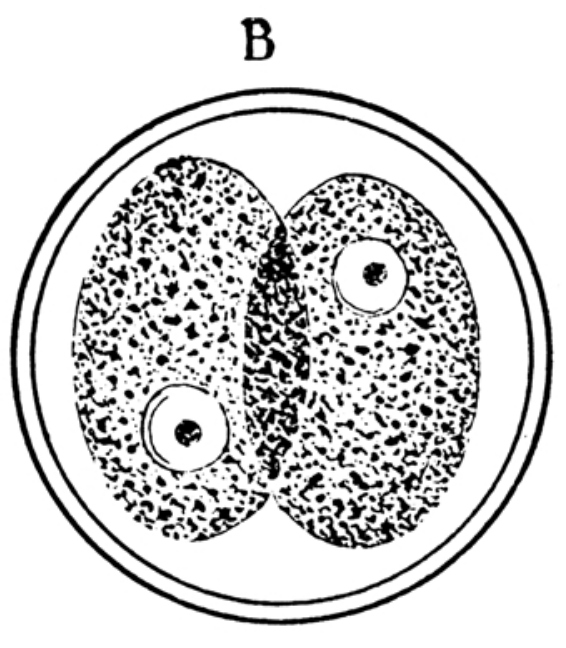

E

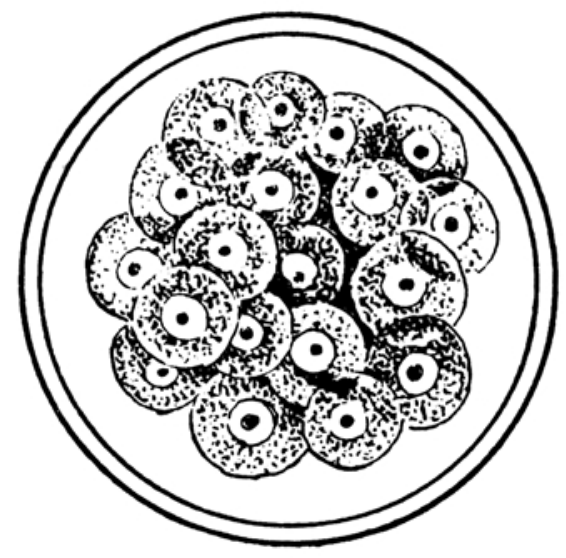

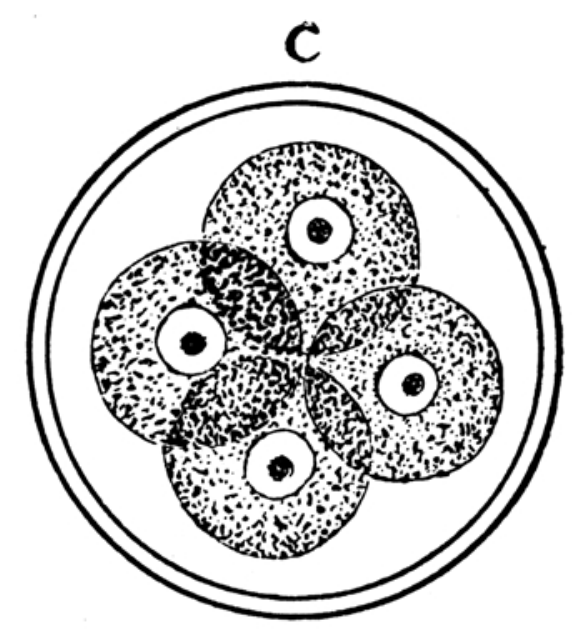

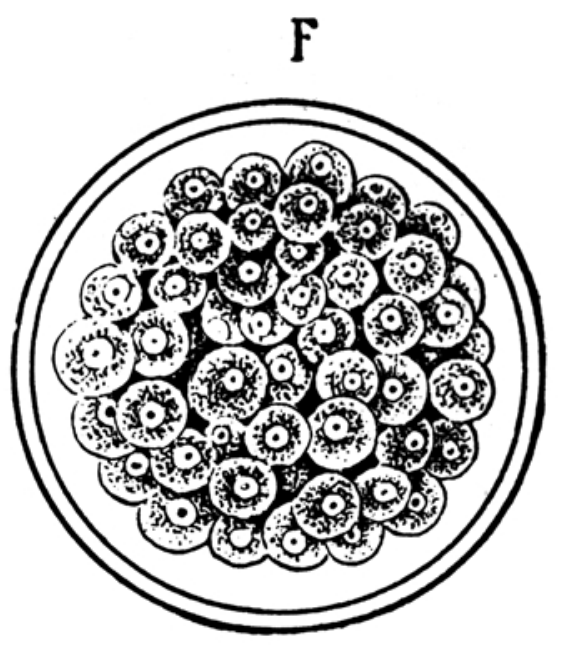

42 Cell Structure 


\subsection{How the Seeds are Packed in the Pomegranate}

Based on cell-packing theory, there are seven possible packing scenarios that fall into three categories.

(Figure 42: Cell Structure, each packing scenario generates boundaries based on the "Circle Set Voronoi / Voronoi" rule)

Circle to Circle

Overlapping - circles that meet at two points.

Intersecting - circles that meet at a single point.

Not intersecting - circles that do not meet.

Circle to Point

Intersecting - a circle and a point that meet at a single point.

Included - a point that is inside of a circle.

Excluded - a point that is outside of a circle.

Point to Point

Not intersecting - points that do not meet.

Not all of the packing examples are meaningful in the case of the pomegranate. So by removing some packing scenarios, we can arrive at three meaningful packing scenarios.

Not intersecting: seeds not adjacent to each other.

Intersecting: seeds adjacent to each other (sometimes separated by tissue). Voids: connection between seeds and a void. 


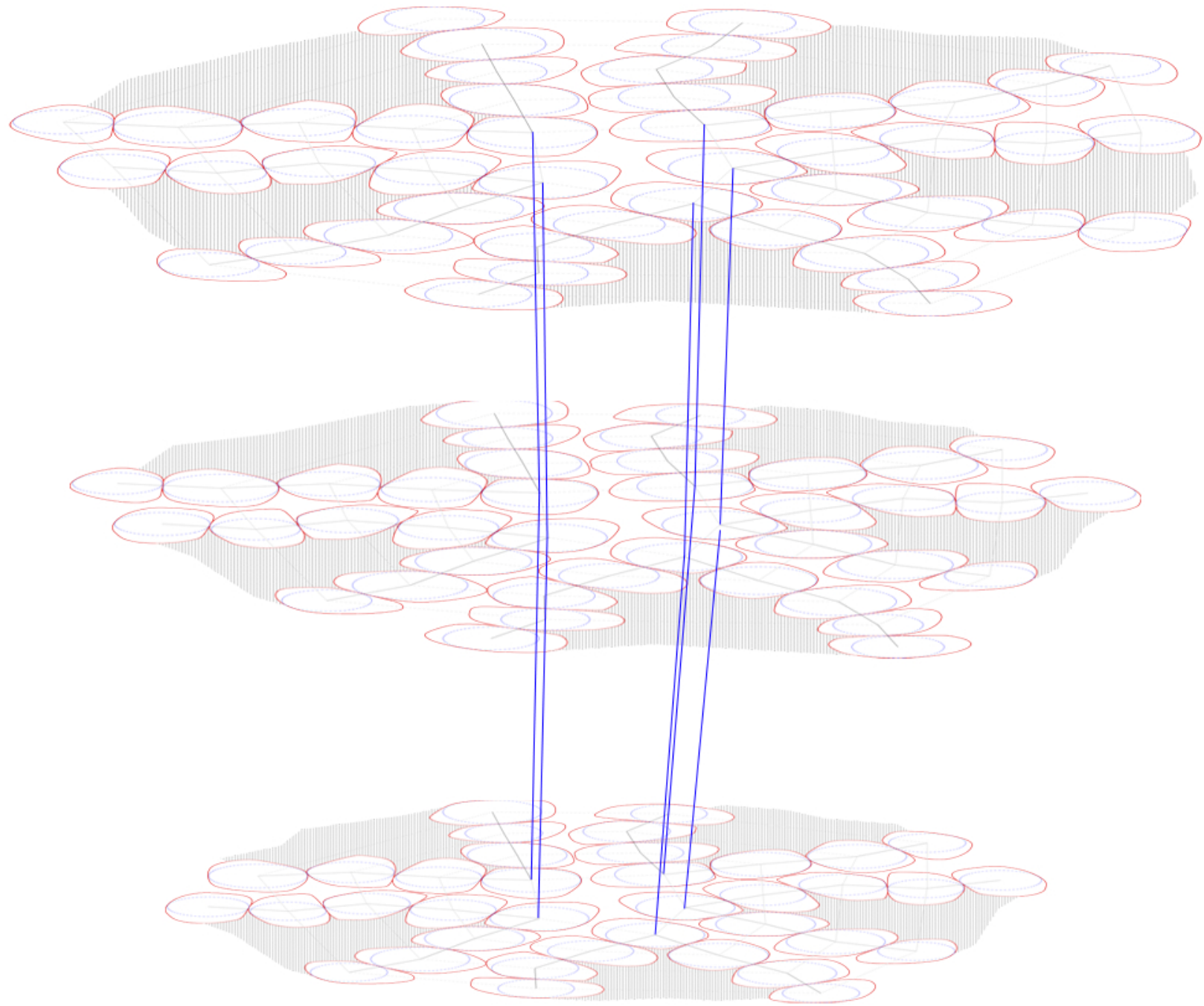

43

43 3D Point Connection 
If more than two seeds are stacked vertically and boundaries formed based on the cell-packing scenarios previously discussed, they will be curvilinear surfaces in section. (Figure 43)

Both the vertical and horizontal connections are meaningful in this case because it supports the relationship investigated in the first part of this study. The seeds are analogous of individual people who form the local culture by which a community is built. The shape of each seed and its effect on the other seeds form the overall shape of the pomegranate, which is analogous of the community.

The simple principle that emerges from this exercise is that, although the seeds can be bundled in many different ways, the shape and stability of the structure is closely related to the geometric configuration of individual seeds and the voids in between them. 
Design Experiment Based on Understanding Pomegranate 


\section{// analogy}

pomegranate back to architecture
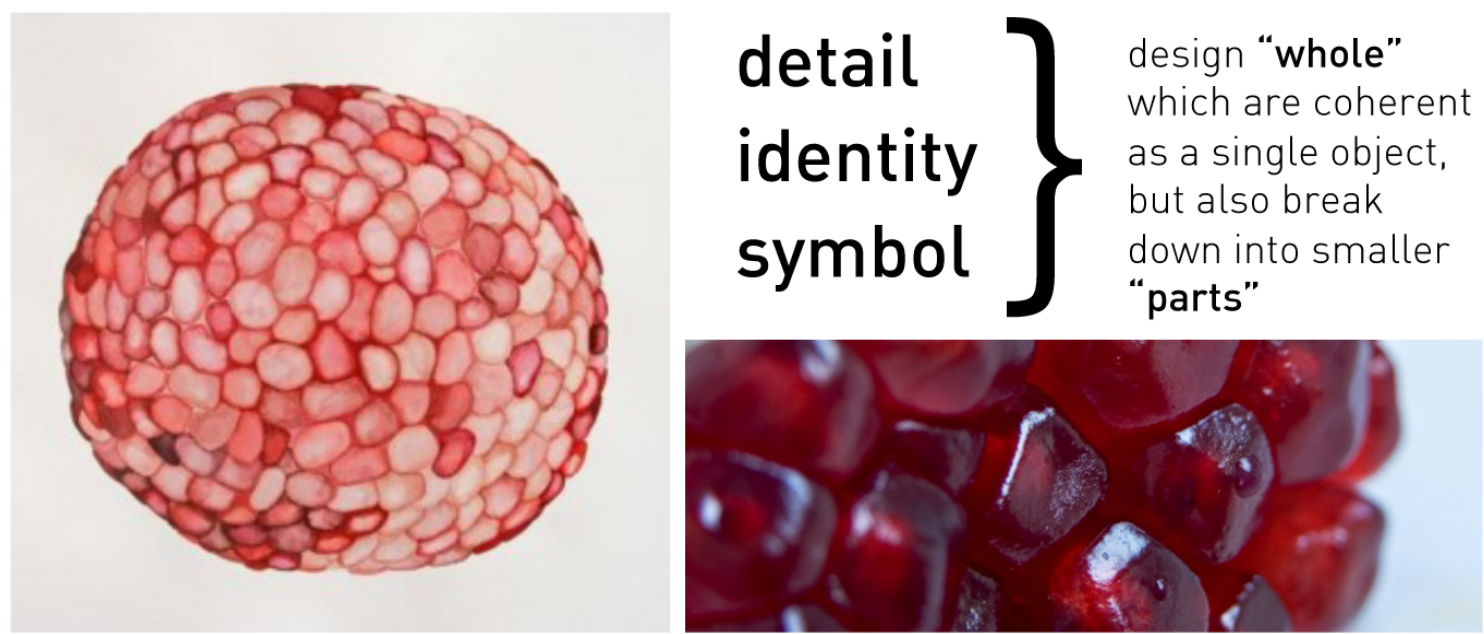


\section{// design exploration}

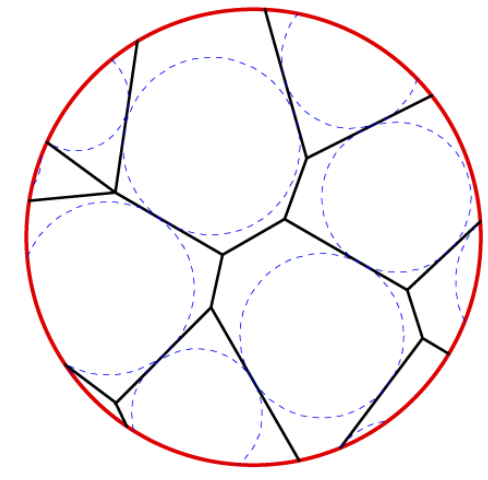

whole

part 
// unfold the cell structure

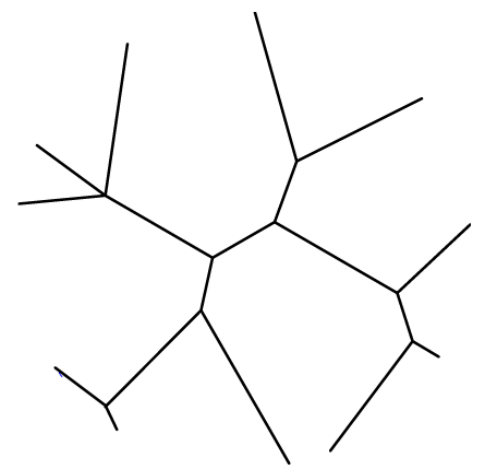




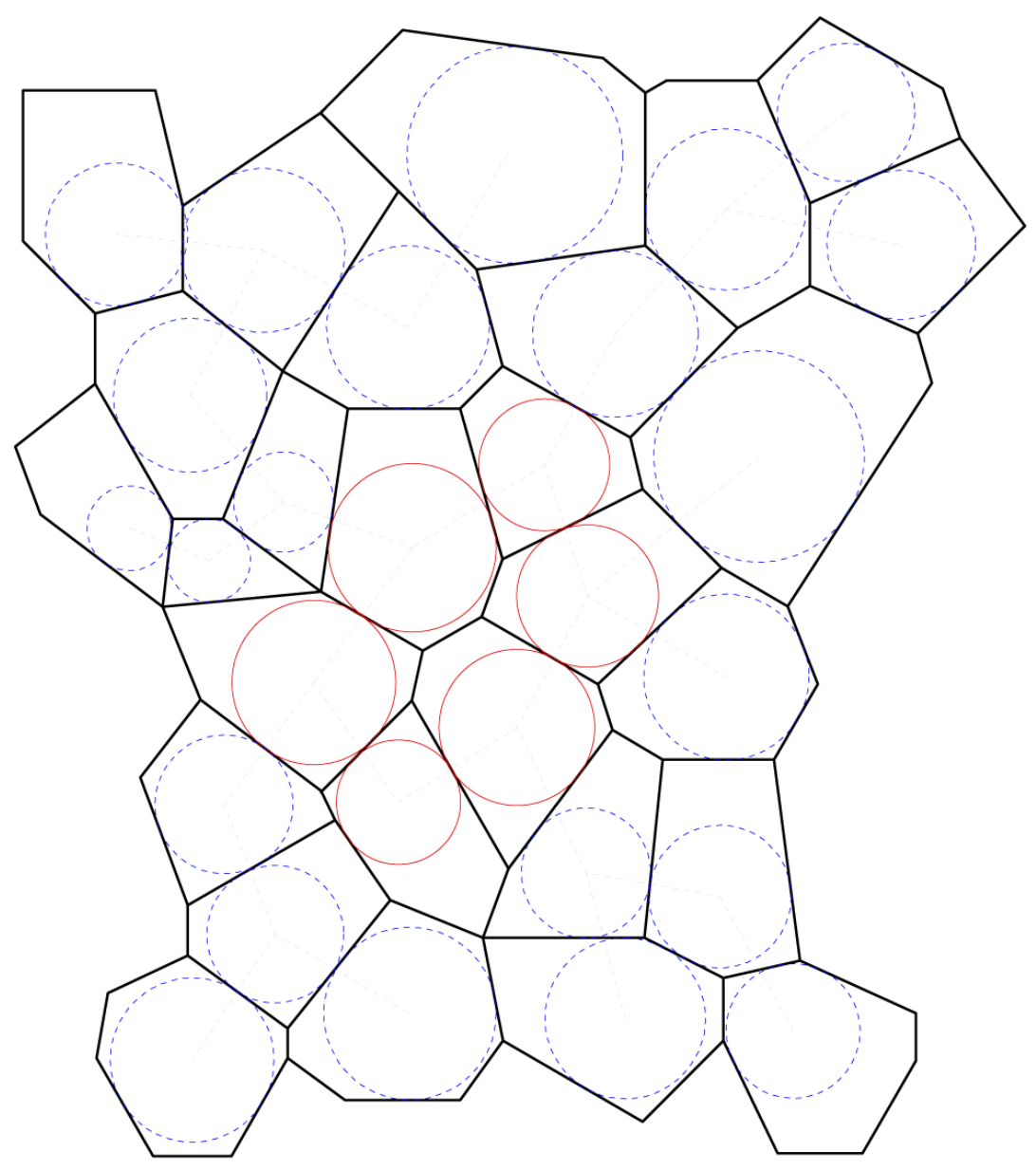


// meaningful scenario

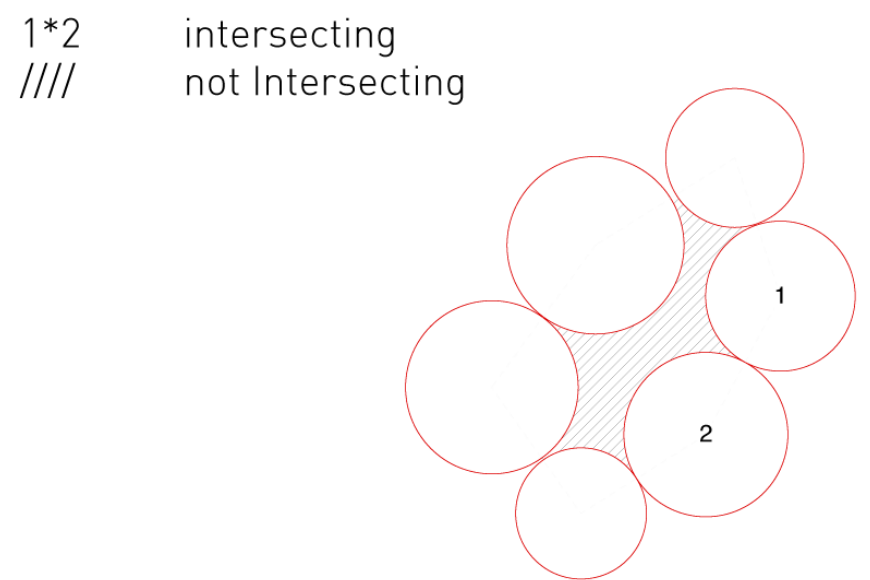




\section{// grasshopper model}

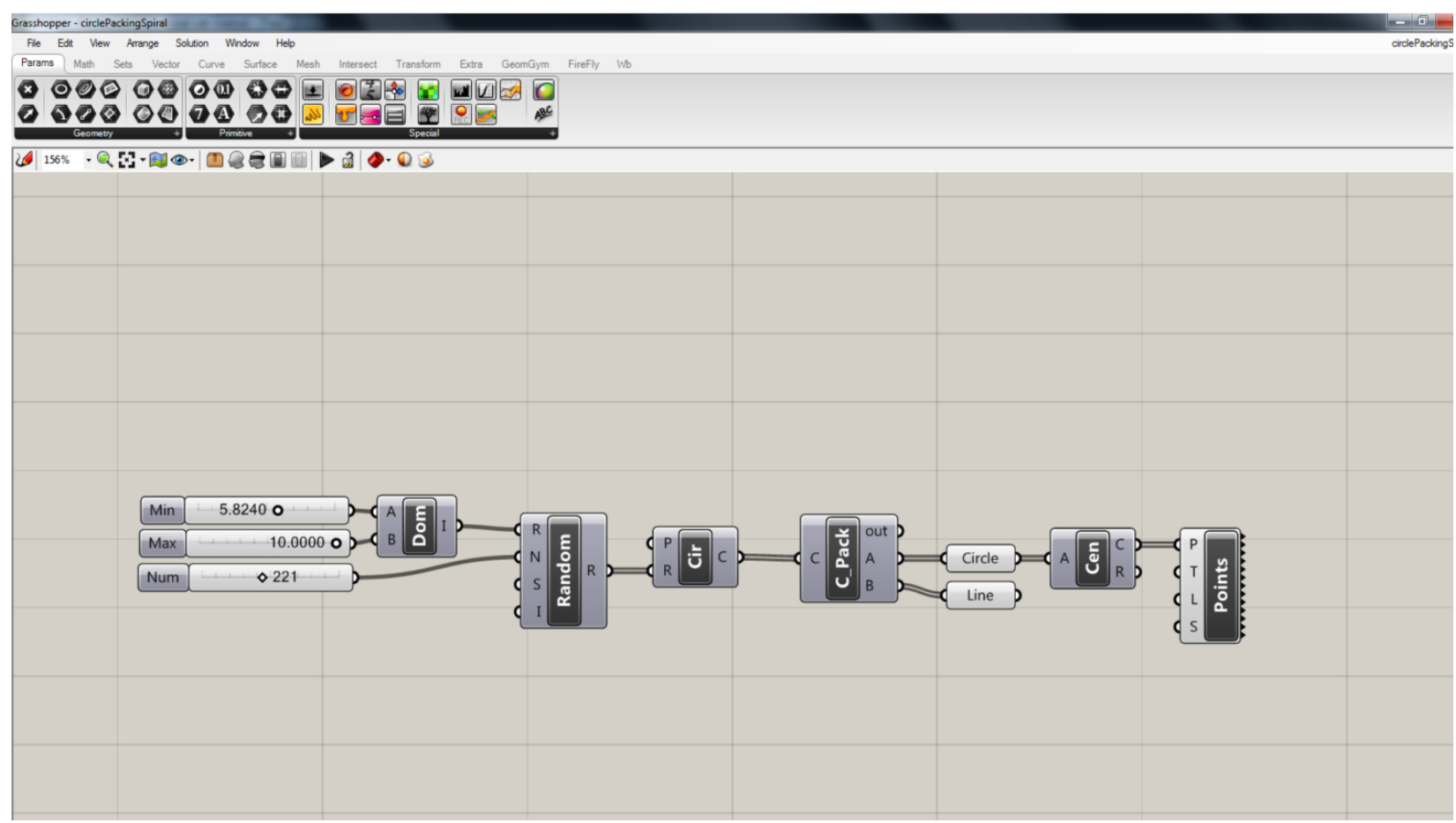




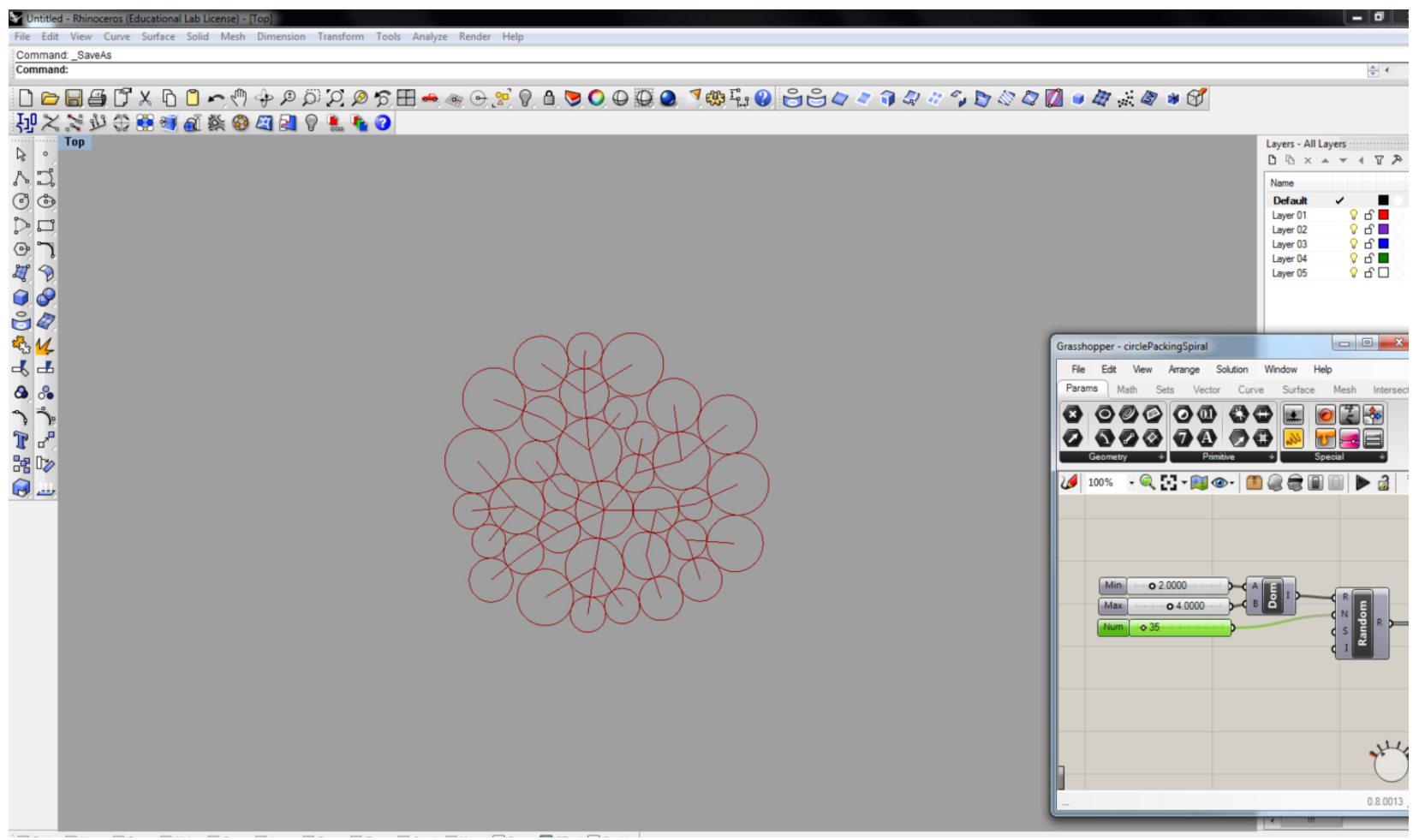


// stacking
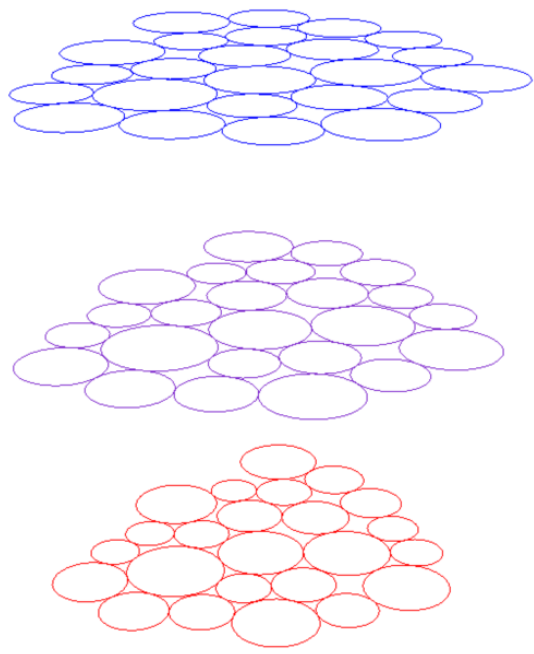


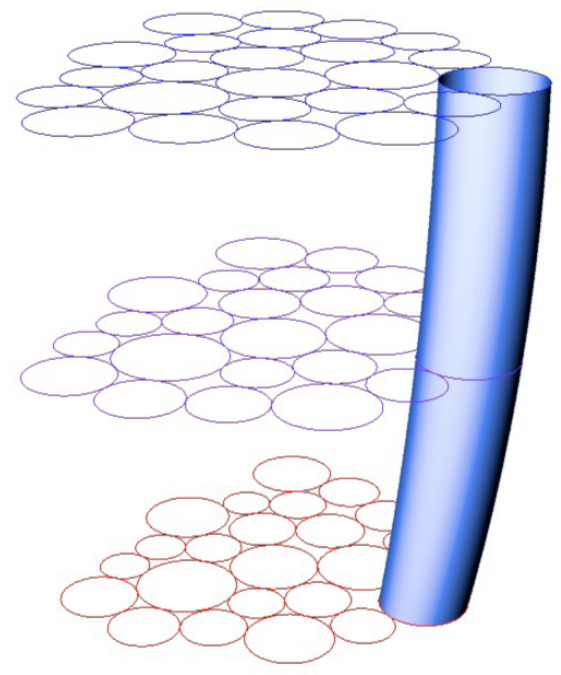



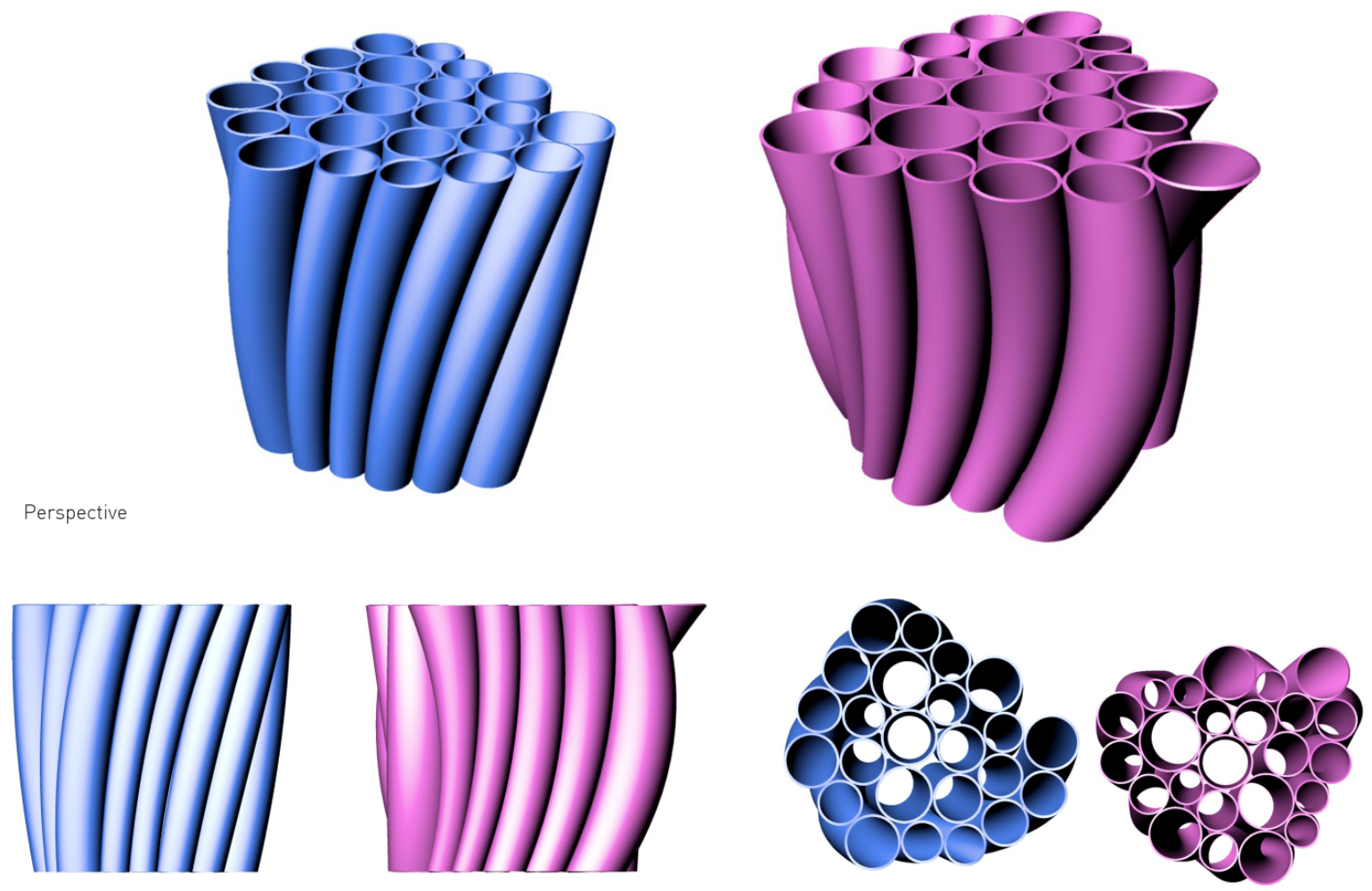
// understanding voids

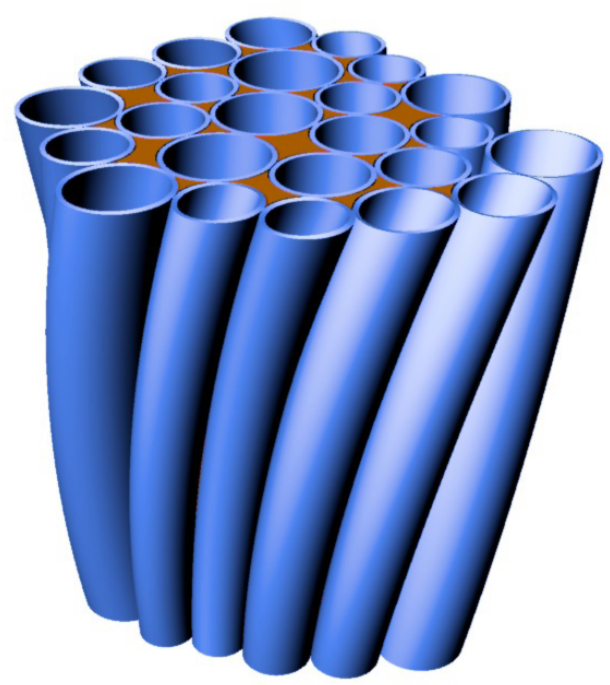




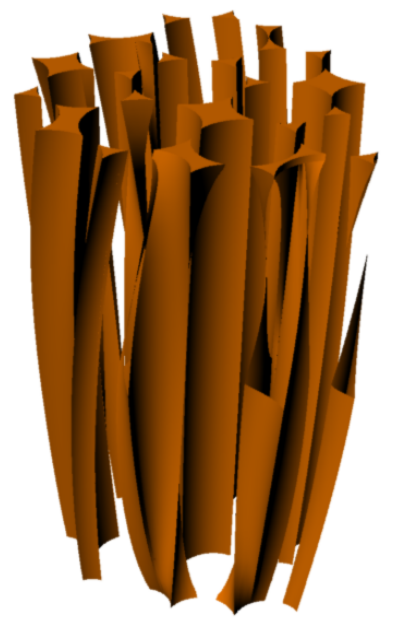



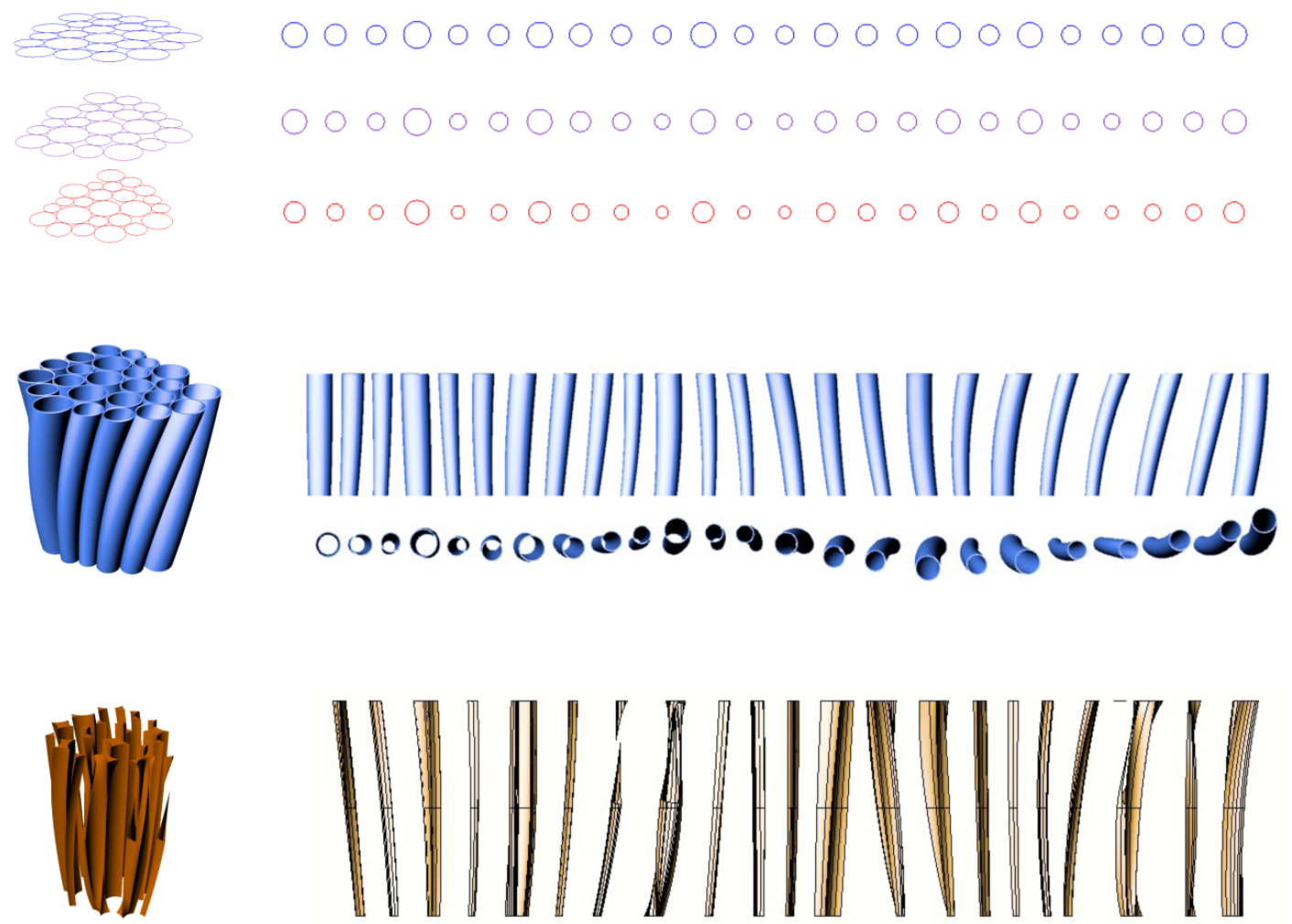


\section{REFERENCE LIST}


Aga Khan Award for Architecture (10th Cycle). Intervention Architecture: Building for Change. London: I.B.Tauris \& Co., 2007

AlSayyad, Nezar. "Consuming Heritage or the End of Tradition." From The Domestic and the Foreign in Architecture edited by Ruth Baumeister and Sang Lee. Rotterdam: 101 Publishers, 2007. pp 179-205

Architecture for Humanity (ed). Design Like you Give a Damn. New York: Metropolis Books, 2006.

Appiah , K. Anthony, Cosmopolitanism, Ethics in a World of Strangers, Princeton University Press 2004.

Balbaa, Taymoore. "Of Water and Earth: Natural Materials, Inspired Form,and Threatened Traditions of Rural Architecture" From Regional Architecture and Identity in the Age of Globalization edited by Jamal Al-Qawasmi, Abdesselem Mahmoud, and Ali Djerbi. (CSAAR 2007 Conference Proceedings)

Battle, Guy. "Sustainable Cities." From The Endless City edited by Ricky Burdett \& Deyan Sudjic. London: Phaidon Press, 2007. pp 386-393

Baydar, Gülsüm. "The Cultural Burden of Architecture." Journal of Architectural Education 57.4 (2004): 19-27. Print.

Benevolo, Leonardo. "The New International Field." From History of Modern Architecture. Volume 2: The Modern Movement. Cambridge, MIT Press, 1985. pp 748-782

Bernard Rudofsky. Architecture without architects: an introduction to nonpedigreed architecture. N.Y., USA: distributed by Doubleday, 1964.

C. Greig Crysler. The SAGE Handbook of Architectural Theory. USA: SAGE Publications Ltd, 2011

Castillo, Jose. "After the Explosion." From The Endless City edited by Ricky Burdett \& Deyan Sudjic. London:Phaidon Press, 2007. pp 174-185

City of Toronto. "Municipal Cultural Planning Indicators \& Performance Measures Guidebook”. Toronto, Canada, 2011.

Cuff, Dana, in her discussion "Scales of Practice: Architecture in the Global Economy,”. California: University of California, 2010

Dodge, Jim. "Living By Life: Some Bioregional Theory and Practice" From Architectural Regionalism: Collected Writings on Place, Identity, Modernity, and Tradition edited by Vincent B. Canizaro. New York: Princeton Architectural Press, 2007. pp 340-349

Eggener, Keith L. "Placing Resistance: A Critique of Critical Regionalism." From Architectural Regionalism: Collected Writings on Place, Identity, Modernity, and 
Tradition edited by Vincent B. Canizaro. New York: Princeton Architectural Press, 2007.

Fathy, Hassan. Architecture for the Poor. An Experiment in Rural Housing. Chicago: University of Chicago Press, 1973

Fathy, Hassan. Natural Energy and Vernacular Architecture: Principles and Examples with Reference to Hot Arid Climates. Chicago: University of Chicago Press, 1986. Part One: Man, Natural Environment, and Architecture."

Frampton, Kenneth. Modern Architecture: A Critical History. London: Thames and Hudson, 1992

Frampton,Kenneth. Labour, work and architecture: collected essay on architecture and design. New York: Phaidon Press.

Frampton,Kenneth. Modern Architecture: A Critical History. London: Thames and Hudson, 1992

Hawkes, Jon. "The Fourth Pillar of Sustainability: Culture's Role." , Melbourne: Common Ground P/L, 2001; ISBN 1863350497

Koolhaas, Rem. "Shopping: Harvard Project on the City" From Mutations edited by Rem Koolhaas, Stefano Boeri, Sanford Kwinter. Barcelona: Actar, 2000. pp124-183

Landry, Charles. "The Creative City: A Toolkit for Urban Innovators".London: Earthscan Publications, 2000

Leakey, Richard \& Lewin, Roger. "The Sixth Extinction" from The Sixth Extinction: Patterns of Life and the Future of Humankind. London: Doubleday, 1995. Chapter 13 pp 232-246

Lewis, Roger. "Architecture and the Global City". University of Maryland School of Architecture, 2002.

Lewis, Roger. "The Structure of the Ordinary". Cambridge, London: MIT Press, 1998.

McMinn, John \& Polo, Marco. 41Åã to 66Åã : Regional Responses to Sustainable Architecture in Canada. (Exhibition Catalogue) Cambridge, Ontario: Design at Riverside, 2005

Mumford, Lewis. "Regional Planning" From Architectural Regionalism: Collected Writings on Place, Identity,Modernity, and Tradition edited by Vincent B.

Canizaro. New York: Princeton Architectural Press, 2007. pp 236-243

Mumford, Lewis. The City in History: Its Origins, Its Transformations, and Its Prospects. New York: Harcourt Brace Jovanovich, 1961. Chapter 16: "Suburbia and Beyond" pp 482-513 
Ozkan, Suha. "Regionalism Within Modernism" From Architectural Regionalism: Collected Writings on Place, Identity, Modernity, and Tradition edited by Vincent B. Canizaro. New York: Princeton Architectural Press, 2007.

Ozkan, Suha. "Regionalism Within Modernism" From Architectural Regionalism: Collected Writings on Place, Identity, Modernity, and Tradition edited by Vincent B. Canizaro. New York: Princeton Architectural Press, 2007.

Pallasmaa, Juhani. Encounters: Architectural Essays. "Tradition and Modernity: The Feasibility of Regional Architecture in Post-Modern Society". Helsinki: Rakennustieto.1988

Parker, Simon, and Niamh Gallagher. The Collaborative State: How Working Together Can Transform Public Services. London: Demos, 2007. Print.

Ritzer, George. "Can Globalized Commercial Architecture be Anything but Highly McDonaldized?" From The Domestic and the Foreign in Architecture edited by Ruth Baumeister and Sang Lee. Rotterdam: 101 Publishers, 2007.

Sewell, John. The Shape of the City: Toronto Struggles with Modern Planning. Toronto: University of Toronto Press, 1993. Chapter 5: "The Rejection of Modern Planning." pp 135-171

Soja, Edward \& Kanai, Miguel. "The Urbanization of the World." From The Endless City edited by Ricky Burdett \& Deyan Sudjic. London: Phaidon Press, 2007.

"Understanding Cultural Sensibility: David Chipperfield in Conversation with Ruth Baumeister." From The Domestic and the Foreign in Architecture edited by Ruth Baumeister and Sang Lee. Rotterdam: 101 Publishers, 2007.

Wood, Phil, and Charles Landry. The Intercultural City: Planning for Diversity Advantage. London: Earthscan, 2008. Print. 
